\title{
Lauraceae Jussieu na Reserva Ecológica de Macaé de Cima, Município de Nova Friburgo, Rio de Janeiro, Brasil ${ }^{\star}$
}

\begin{abstract}
Alexandre Quinet ${ }^{1,2}$
Regina Helena Potsch Andreata 3,4

\section{RESUMO}

Este trabalho apresenta o estudo taxonômico das espécies de Lauraceae na Reserva Ecológica de Macaé de Cima, localizada no Município de Nova Friburgo, no estado do Rio de Janeiro, Brasil. A vegetação da Reserva é do tipo Floresta Pluvial Atlântica Montana com altitudes entre 880 a $1.720 \mathrm{~m}$. Com base nas coleções botânicas depositadas em vários herbários, especialmente nas do Instituto de Pesquisas do Jardim Botânico do Rio de Janeiro, e em trabalho de campo, foram reconhecidas para a região 32 espécies subordinadas a nove gêneros: Aniba (1 sp.), Beilschmiedia (2 spp.), Cinnamomum (2 spp.), Cryptocarya (2 spp.), Endlicheria (1sp.), Nectandra (3 spp.), Ocotea (18 spp.), Persea (2 spp.) e Rhodostemonodaphne (1 sp.). O tratamento da família compreende descrições morfológicas das espécies, comentários e ilustrações. São fornecidos, também, dados sobre a distribuição geográfica, habitat, época de floração e frutificação, utilidade, além de uma chave analítica para a identificação dos gêneros e espécies ocorrentes na área. Revalidaram-se os binômios Ocotea domatiata Mez, O. pulchra Vattimo-Gil e O. teleiandra (Meisn.) Mez. Ampliou-se a distribuição geográfica conhecida de Cinnamomum glaziovii (Mez) Kosterm. e Ocotea urbaniana Mez. Descreveu-se pela primeira vez o fruto de O. domatiata Mez e de Cinnamomum glaziovii (Mez) Kosterm.
\end{abstract}

Palavras chave: Lauraceae, Taxonomia, Morfologia, Mata Atlântica, Rio de Janeiro

\section{ABSTRACT}

This paper presents the taxonomic study of the Lauraceae species from the Reserva Ecológica de Macaé de Cima, located in the municipality of Nova Friburgo, Rio de Janeiro State, Brazil. The vegetation of the Reserve is classified as Montane Atlantic Rain Forest type with altitudes ranging from 880 to $1720 \mathrm{~m}$ a.s.l. Supported by botanical collections deposited in several herbaria, particularly those of the Instituto de Pesquisas do Jardim Botânico do Rio de Janeiro, 32 species and nine genera were recognized: Aniba (1 sp.), Beilschmiedia (2 spp.), Cinnamomum (2 spp), Cryptocarya (2 spp.), Endlicheria (1 sp.), Nectandra (3 spp.), Ocotea (18 spp.), Persea (2 spp.), Rhodostemonodaphne (1 sp.). The treatment of the family includes species morphologic description, comments and illustration. Survey also included the gathering of data on species geographical distribution, habitat, flowering and fruitification seasons, uses, as well as an analytical key for genera and species identification in the area. The binomial Ocotea domatiata Mez, O. pulchra Vattimo-Gil and O. teleiandra (Meisn.) Mez were confirmed to be valid. The known geographical distribution of Cinnamomum glaziovii (Mez) Kosterm. and Ocotea urbaniana Mez has been extended. The fruit of $O$. domatiata Mez and Cinnamomum glaziovii (Mez) Kosterm. was described for the first time.

Keywords: Lauraceae, Taxonomy, Morphology, Mata Atlântica, Rio de Janeiro

* Parte da Dissertação de Mestrado apresentada à Coordenação do Curso de Pós-Graduação (Botânica) do Museu Nacional / Universidade Federal do Rio de Janeiro.

1 Bolsista da Fundação Margaret Mee.

2 Instituto de Pesquisas Jardim Botânico do Rio de Janeiro.

Rua Pacheco Leão 915, Jardim Botânico, Rio de Janeiro, RJ, CEP 22460.030.

3 Universidade Santa Úrsula, ICBA, Rua Fernando Ferrari, Botafogo, RJ, CEP 22.231-040.

${ }^{4}$ Bolsista de Produtividade do CNPq. 


\section{INTRODUÇÃO}

As Lauraceae têm distribuição pantropical, sendo bem representadas na América, Ásia tropical, Austrália e Madagascar, e pouco expressivas no sul da África, possuindo 2.500 espécies subordinadas a 50 gêneros (Rohwer, 1986). No Brasil, ocorrem 19 gêneros e cerca de 390 espécies que habitam, em sua maior parte, as Florestas Pluviais e também as Restingas e os Cerrados (Barroso, 1978).

O potencial econômico das espécies dessa família é conhecido desde os tempos remotos, através de documentos da China de 2800 a.C., onde já era empregado o óleo de Cinnamomum camphora (L.) J.Presl e de outras espécies do gênero na medicina (Sangirardi Jr., 1984). As folhas de Laurus nobilis L., o loureiro, eram utilizadas pelos antigos gregos e romanos para confeccionar coroas, com as quais se homenageavam guerreiros e atletas vitoriosos, e estão entre os condimentos conhecidos da culinária de todo o mundo. $\mathrm{O}$ produto alimentício mais comercializado em quase toda a América é o fruto de Persea americana Mill., o abacateiro, do qual também se extrai, do mesocarpo e da semente, o óleo para a fabricação de cosméticos. No Brasil, destacam-se especialmente as espécies de Ocotea e de Nectandra, conhecidas popularmente como canelas, loureiros ou embuias, que remontam ao começo da colonização, quando foram exploradas para o emprego na construção naval e movelaria de luxo (Cante, 1988). Essa importância econômica que as Lauraceae apresentam e a inexistência de programas efetivos de manejo florestal são alguns dos fatores que colocam sob perigo de extinção a maior parte das suas espécies (Araújo, 1994).

Entre os trabalhos taxonômicos clássicos sobre as Lauraceae podem ser citados os de Nees (1833, 1836), Meisner (1864, 1866) e Mez (1889). Os tratamentos mais relevantes sobre as espécies neotropicais são os de Allen (1945, 1966), Kostermans (1936, 1937, 1938a, 1938b, 1952, 1953, 1957, 1961, 1970/74), Kubitzki \& Renner (1982), Werff (1984, 1987, 1991, 1994,
1996), Rohwer (1986, 1993 a, 1993b), Rohwer et al. (1991) e Lorea-Hernandez (1998). Dentre os estudos realizados no Brasil, destacamse os de Vattimo-Gil (1956a, 1956b, 1956c, 1957, 1958, 1959a, 1959b-1961a, 1960-1961b, 1966a, 1966b, 1976, 1979d), Coe-Teixera $(1963,1964,1965,1975,1980)$, Baitello \& CoeTeixeira (1987) e, mais recentemente, os de Araujo (1994) e Nicolau (1999). A família vem sendo apontada como uma das mais representativas, tanto em número de indivíduos quanto em riqueza de táxons, nos inventários florísticos e fitossociológicos realizados em áreas de florestas bem preservadas da porção sudeste-sul do país, fato este que corrobora a hipótese de que esta região seja um dos principais centros de diversidade deste grupo (Vattimo-Gil, 1959a).

Levando-se em conta a expressividade das Lauraceae, tanto a nível genérico quanto específico, na composição da flora arbórea em Floresta Pluvial Atlântica do estado do Rio de Janeiro registrada por diversos autores (Guedes-Bruni, 1998; Kurtz, 1994; Rodrigues, 1996; Guedes-Bruni et al. 1997), escolheu-se esta família como tema para a dissertação.

A Reserva Ecológica de Macaé de Cima, situada na porção central do estado do Rio de Janeiro, no município de Nova Friburgo, encontra-se incluída na mancha florestal contínua da Serra do Mar, constituindo um importante remanescente da vegetação primária de Floresta Pluvial Atlântica (Lima \& Guedes-Bruni, 1997).

Um inventário florístico e fitossociológico intensivo realizado na área pela equipe do Programa Mata Atlântica, do Instituto de Pesquisas Jardim Botânico do Rio de Janeiro, disponibilizou um acervo valioso sobre a família, o que permitiu o desenvolvimento deste trabalho.

O trabalho teve por objetivo estudar as espécies de Lauraceae ocorrentes na Reserva Ecológica de Macaé de Cima, ampliando o conhecimento morfológico e taxonômico da família na Floresta Pluvial Atlântica do estado do Rio de Janeiro. 


\section{Histórico da família Lauraceae}

Linnaeus (1753) descreveu pela primeira vez as espécies do gênero Laurus, sendo este, juntamente com outros cinco gêneros, subordinados à classe Enneandria.

Aublet (1775) estabeleceu os novos gêneros Aiouea, Aniba, Ocotea e Licaria.

Jussieu (1789) reuniu as espécies até então conhecidas na ordem Lauri, considerando os gêneros Aiouea, Laurus, Ocotea e Myristica.

Nees (1836), o primeiro monografista do grupo, descreveu cerca de 400 espécies subordinadas a 45 gêneros divididos em 13 tribos. Baseou-se no tipo de inflorescência, perigônio, sexo da flor e forma dos estames para a delimitação dos gêneros. $O$ trabalho foi de grande importância para a taxonomia das Lauraceae, apesar dos conceitos utilizados pelo autor não serem aceitos integralmente pelos demais, sendo 27 táxons sinonimizados posteriormente.

Meisner (1864), procurando estabelecer caracteres menos artificiais para os táxons da família, dividiu as Lauraceae em três subordens, Laurinae, Gyrocarpae e Cassytha, com um total de 54 gêneros, dando mais importância ao aspecto carpológico. Posteriormente, em 1866, publicou na Flora Brasiliensis, a revisão das espécies que ocorrem no Brasil, reconhecendo 26 gêneros, subordinados a seis tribos incluídas nas três subordens citadas anteriormente.

Bentham (1880) dividiu a família em três tribos, baseadas em hábito e tipo de inflorescência: 1- ervas parasitas sem folhas - tribo Cassytheae; árvores ou arvoretas: 2- com inflorescência sem invólucro - tribo Perseae; 3- com inflorescência involucrada - tribo Litseae.

Pax (1894), na sua revisão da família, subdividiu-a em duas subfamílias, levando em conta o número de locelos das anteras, denominando-as Lauroideae (anteras com dois locelos) e Persoideae (anteras com quatro locelos).

Mez (1889), na monografia sobre as Lauraceae americanas, descreveu dois novos gêneros, Systemonodaphne e Urbanodendron e 123 espécies novas. Dividiu a família em duas subordens, Laureae e Cassytheae. Esta, formada apenas por um gênero de ervas parasitas, folhas reduzidas ou ausentes. As Laureae divididas em duas tribos, Perseae e Litseae, baseadas na presença ou ausência de invólucro nas inflorescências e os gêneros no número de células das anteras.

Kostermans (1957) apresenta uma nova classificação para a família dividindo-a em duas subfamílias: Lauroideae (árvores ou arbustos) $e$ Cassythoideae (ervas), reconhecendo cinco tribos. Uma delas é caracterizada pela inflorescência com invólucro, sendo as outras quatro tribos não involucradas, divididas pela ausência ou presença de cúpula no fruto. A tribo Perseae é reconhecida pela completa ausência de cúpula. A tribo Litseae com a base dos frutos sobre ou parcialmente envolvidos por cúpula (ex: Cinnamomum, Pleurothyrium, Ocotea, Nectandra). A tribo Cryptocaryineae e a tribo Hypodaphneae tendo o fruto completamente envolvido pelo tubo floral, sendo a primeira caracterizada pela presença de ovário súpero (ex.: Cryptocarya) e a segunda pelo ovário ínfero (somente o gênero Hypodaphnis).

Allen (1966) defende a separação dos gêneros Pleurothyrium e Nectandra de Ocotea.

Vattimo-Gil (1956-1996) publicou diversos trabalhos que contribuíram para o conhecimento das espécies da família no Brasil, principalmente, no estado do Rio de Janeiro, sendo vários os estudos sobre gêneros e espécies da Mata Atlântica. Descrevendo muitas espécies novas, algumas sinonimizadas posteriormente.

Coe-Teixeira $(1963,1964,1965,1975$, 1980) estudou as Lauraceae do Estado de São Paulo, descrevendo detalhadamente várias espécies, pertencentes aos gêneros Beilschmiedia, Endlicheria, Aniba, Nectandra, Cryptocarya, Persea e Ocotea.

Richter (1981) classificou a família utilizando-se de caracteres da anatomia das raízes e madeira, dividindo-a em três grandes grupos: Perseae, Laureae e Cryptocaryeae. 
Kubitzki \& Renner (1982) revisaram os gêneros Aniba e Aiouea para a Flora Neotrópica.

Rohwer (1986) faz a primeira tentativa de uma revisão do gênero Ocotea em Prodromus einer Monographie. Neste mesmo ano, publica a revisão de Nectandra na Flora Neotrópica.

Baitello \& Coe-Teixeira (1987) trataram as Lauraceae do Parque Estadual das Fontes do Ipiranga, no município de São Paulo, reconhecendo 25 espécies para a área.

Rohwer (1993b), baseando-se no tipo de inflorescência, caracteres florais, informações anatômicas, embriológicas e químicas, subdividiu a família em duas tribos - Laureae e Perseae - e em 52 gêneros.

Araujo (1994) estudou sete espécies de Beilschmiedia do estado do Rio de Janeiro.

Moraes \& Paoli (1995) estudaram a dispersão e germinação de três espécies dos gêneros Cryptocarya, Endlicheria e Ocotea. Em 1996, os autores estudaram a morfologia de frutos e sementes das espécies tratadas anteriormente.

Werff \& Richter (1996) propuseram a mais recente classificação para a família, utilizando o tipo de inflorescência associado a caracteres anatômicos relativos a madeira e casca, definindo três tribos para a família: Laureae, Perseae, Cryptocaryeae.

Lorea-Hernández (1998) revisou as espécies neotropicais de Cinnamomum, onde incluiu espécies consideradas anteriormente pertencentes a Phoebe, e apontou novos caracteres para a delimitação do gênero. Reconheceu um total de 47 táxons. Nishida (1999) faz a revisão de Beilschmiedia tratando de 28 espécies para os neotrópicos, divididas em cinco grupos, pelos caracteres anatômicos das folhas.

A circunscrição dos gêneros tem sido interpretada diferentemente por diversos botânicos, como Nees (1836), Meisner (1864), Bentham (1880), Pax (1894) e Mez (1889). O grau de importância atribuído à utilização de caracteres florais por estes autores, como estrutura das inflorescências, sexualidade, número e disposição de estames e locelos e desenvolvimento do hipanto no fruto em detrimento de caracteres vegetativos, mostraram-se, muitas vezes, inadequados devido à superposição dos mesmos em espécimes intermediários. Daí a relevância do uso de outros atributos associados a estes, tais como a anatomia de raízes e madeira (Richter, 1980, 1981, 1985) e venação foliar (Nishida, 1999), que muito contribuem para a delimitação dos táxons, tanto genéricos quanto específicos. No tocante às classificações para a família, podese destacar a mais recente proposta de Werff \& Richter (1996), com a qual concorda-se neste trabalho.

\section{Área de estudo}

A Reserva Ecológica de Macaé de Cima, localizada no estado do Rio de Janeiro, distrito de Macaé de Cima, município de Nova Friburgo, possui uma área de 7.200 hectares, tendo como divisa os municípios de Cachoeira de Macacu, a sudoeste, e Silva Jardim, a sudeste. Geograficamente, situa-se na Serra do Mar, englobando a Serra de Macaé de Cima a noroeste, a sudoeste a Serra de São João e a sudeste a Serra do Taquaruçú, entre as coordenadas, $22^{\circ} 21^{\prime}$ e $22^{\circ} 28^{\prime}$ ' S; 42 $2^{\circ} 27^{\prime}$ e $42^{\circ} 35^{\prime}$ W (Fig. 1).

O relevo fortemente ondulado caracteriza-se por altitudes que variam entre 880 a 1.719 metros sobre o nível do mar. Tem como pontos culminantes a Pedra do Faraó, com $1.719 \mathrm{~ms} . \mathrm{m}$., sendo este o ponto mais elevado da Reserva, a pedra de São Caetano, com 1.657 ms.m., de São João, com 1.637 ms.m., e da pedra da Bicuda, com 1499 ms.m.

A região de Macaé de Cima é formada basicamente por rochas metamórficas précambrianas pertencentes às Unidades do Desengano, São Fidélis e São Eduardo. Na Reserva, são encontradas rochas proterozóicas na Pedra Bicuda e Pedra do Faraó, enquanto há pequenos depósitos aluvionares quaternários no vale do rio Macaé. O solo da região é do tipo cambissolo álico "A" 


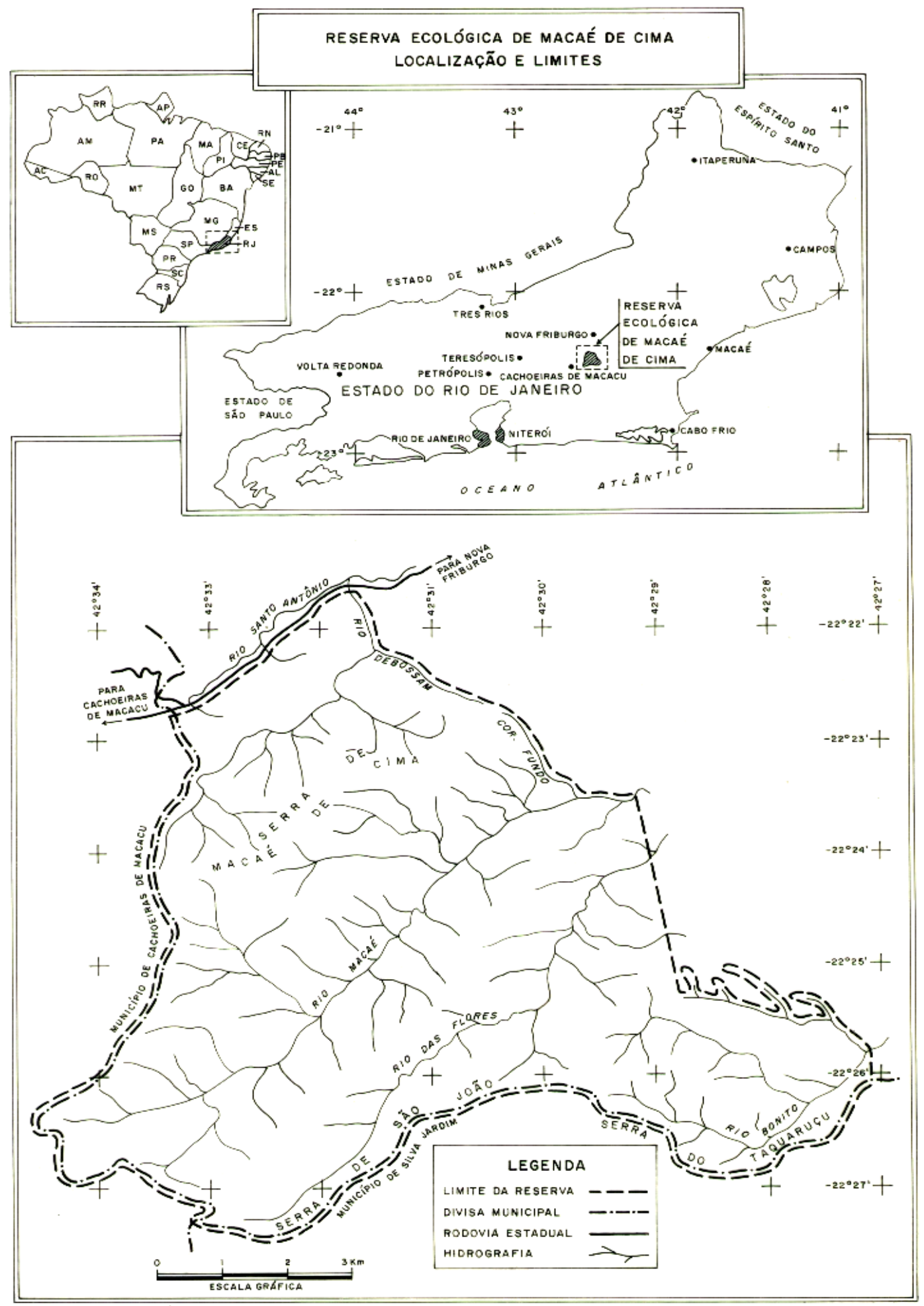

Figura 1 - Mapas da Reserva Ecológica de Macaé de Cima, localizada no município de Nova Friburgo, no estado do Rio de Janeiro (Fonte: Programa Mata Atlântica/JBRJ). 
(Nimer, 1989).

Grande parte da Reserva localiza-se na bacia hidrográfica do rio Macaé e seu afluente rio das Flores, cujos vales apresentam uma altitude média de $1.100 \mathrm{~ms} . \mathrm{m}$., correndo no sentido SO-NE, formando dois vales com 9 km de extenção (Guedes-Bruni, 1998).

O clima regional é do tipo A-superúmido e B'-mesotérmico, na classificação de Tornthwaite \& Mather (1955), correspondendo ao tipo Cfb de Koeppen (Bernardes, 1952). A temperatura média anual é de $17,9^{\circ} \mathrm{C}$, sendo janeiro, fevereiro e março os meses mais quentes, e junho, julho e agosto os meses mais frios. A precipitação média anual é de $2.128 \mathrm{~mm}$, sendo o período de outubro a março o de maior precipitação, enquanto o de julho a agosto é o de menor (Lima \& Guedes-Bruni, 1997).

A vegetação, segundo a classificação de Rizzini (1979), é do tipo Floresta Pluvial Atlântica Montana, ocorrendo nas porções mais elevadas, acima de 1.500 metros de altitude, formações de mata nebular e de Campos de Altitude. A unidade representa um importante remanescente da antiga cobertura florestal que se estendia por toda a Serra do Mar, pois abriga uma considerável área de vegetação nativa e bem preservada (Lima \& Guedes-Bruni, 1997).

A floresta úmida, margeada por pequenos córregos da bacia do Rio Macaé e seu afluente rio das Flores, forma um dossel que se situa entre 12 e $20 \mathrm{~m}$ de altura, com emergentes alcançando $40 \mathrm{~m}$ de altura, com subbosque denso e diversificado.

As famílias mais ricas do dossel são Melastomataceae, Lauraceae, Myrtaceae, Leguminosae e particularmente abundantes são as espécies de Ocotea sp., Alchornea triplinervia (Spreng.) Müll. Arg. (Euphorbiaceae), Cabralea canjerana (Vell.) Mart. subsp. canjerana (Meliaceae), Tibouchina sp. (Melastomataceae), Euterpe edulis Mart. (Arecaceae). Entre as árvores emergentes são expressivos os elementos como Beilschmiedia rigida (Mez) Kosterm., Ocotea sp. (Lauraceae), Ormosia sp., Sclerolobium sp. (Leguminosae), Cariniana estrelensis (Raddi) O. Kuntze (Lecythidaceae). No sub-bosque, destacam-se Melastomataceae (Leandra sp., Miconia sp.), Rubiaceae (Psychotria sp., Rudgea spp.), Palmae (Geonoma sp.) e fetos arborescentes (Pteridophyta), dando um aspecto denso a mata. No estrato herbáceo, encontram-se principalmente Begoniaceae, Piperaceae, Araceae (Anthurium sp Philodendron sp., Xanthosoma sp.), Orchidaceae e Bromeliaceae.

São freqüientes as trepadeiras, hemiepífitas e sobretudo as epífitas, entre as quais podem ser observadas numerosas espécies de Bromeliaceae, Orchidaceae, Araceae e Polypodiaceae, além de muitos líquens e briófitas.

\section{MATERIAL E MÉTODOS}

O levantamento florístico da Reserva Ecológica de Macaé de Cima foi realizado pelos integrantes do Programa Mata Atlântica do Instituto de Pesquisas Jardim Botânico do Rio de Janeiro, durante o período de 1989 a 1991, do qual utilizou-se para este trabalho a coleção referente à família Lauraceae. O material foi obtido de coletas assistemáticas em diversas áreas da Reserva e, em sua maior parte, de duas áreas definidas para estudos fitossociológicos, cada uma com um hectare. A área em melhor estado de conservação, designada área 1 , situa-se às margens do rio das Flores ,e a área alterada, nas proximidades do rio Macaé, designada de área 2. Foram organizadas quatro excursões nos anos de 1999 e 2000, a fim de complementar-se as coletas cujos espécimes encontravam-se em estado vegetativo e para as observações de populações em campo. A coleção botânica foi herborizada segundo as técnicas usuais utilizadas em trabalhos de taxonomia e encontra-se depositada no herbário do Instituto de Pesquisas Jardim Botânico do Rio de Janeiro (RB), com duplicatas distribuídas a diversas Instituições nacionais e estrangeiras.

Quando o material da área de estudo era insuficiente para as descrições ou para complementar a distribuição geográfica dos táxons 
especialmente para o Brasil, foram acrescentados espécimes provenientes de outras localidades, estando estes citados em material adicional. Os espécimes examinados, assim como as duplicatas, fazem parte do acervo das Instituições discriminadas abaixo, em ordem alfabética das siglas designativas, segundo Holmgren et al. (1990).

ALCB Herbário Alexandre Leal Costa, Instituto de Biologia, Universidade Federal da Bahia, Salvador, Bahia, Brasil; BHCB - Herbário, Departamento de Botânica, ICB, Universidade Federal de Minas Gerais, Belo Horizonte, Minas Gerais, Brasil; CEPEC - Herbário CEPEC, CEPLAC, Ilhéus, Bahia, Brasil; CHI - Herbarium, Biological Sciences Department, University of Illinois, Chicago, Illinois, U.S.A; F- Herbarium, Botany Department, Field Museum of Natural History, Chicago, Illinois, U.S.A; FCAB - Herbário Friburguense, NIMA, PUC-Rio, Rio de Janeiro; FLOR Herbário Horto Botânico, Universidade Federal de Santa Catarina, Florianópolis, Santa Catarina, Brasil; GUA - Herbário Alberto Castellanos, FEEMA, Centro de Botânica do Rio de Janeiro, Rio de Janeiro, Rio de Janeiro, Brasil; HB - Herbarium Bradeanum, Rio de Janeiro, Rio de Janeiro, Brasil; HBG- Herbarium, Institut für Allgemeine Botanik, Hamburg, Federal Republic of Germany; HBR - Herbário Barbosa Rodrigues, Itajaí, Santa Catarina, Brasil; HRB - Herbário, RADAMBRASIL, DRN-BA, IBGE, Salvador, Bahia, Brasil; IBGE - Herbário, Reserva Ecológica do IBGE, Brasília, Distrito Federal, Brasil; ICN - Herbário, Departamento de Botânica, Universidade Federal do Rio Grande do Sul, Porto Alegre, Rio Grande doSul, Brasil; INPA - Herbário, Departamento de Botânica, Instituto Nacional de Pesquisas daAmazônica, Manaus, Amazonas, Brasil; IPA - Herbário, Laboratório de Botânica, Empresa Pernambucana de Pesquisa Agropecuária, IPA, Recife, Pernambuco, Brasil; K - Herbarium, Royal Botanic Gardens, Kew, Richmond, England, U.K; M Herbarium, Botanische Staatssammlung, München, Federal Republic of Germany; MBM - Herbário, Museu Botânico Municipal, Curitiba,
Paraná, Brasil; MG - Herbário, Departamento de Botânica, Museu Paraense Emílio Goeldi, Belém, Pará, Brasil; MO- Herbarium, Missouri Botanical Garden, Saint Louis, Missouri, U.S.A; NY-Herbarium, New York Botanical Garden, New York, U.S.A.; P - Herbier, Laboratoire de Phanérogamie, Muséum National d'Histoire Naturelle, Paris, France; PKDC -Herbário, Secretaria Municipal do Meio Ambiente, Divisão de Museu de História Natural, Curitiba, Paraná, Brasil; PY - Herbario, Centro de Estudios y Colecciones Biológicas para la Conservación, Asunción, Paraguay; SP - Herbário, Instituto de Botânica, São Paulo, São Paulo, Brasil; SPSF Herbário, Seção de Madeiras e Produtos Florestais, Instituto Florestal, São Paulo, São Paulo, Brasil; UB - Herbário, VEG-IB, Universidade de Brasília, Brasília, D.F., Brasil; UEC - Herbário, Departamento de Botânica, IB, Universidade Estadual de Campinas, Campinas, São Paulo, Brasil; UFP - Herbário-UFP, Departamento de Botânica, Universidade Federal de Pernambuco, Recife, Pernambuco, Brasil; UNB - Connell Memorial Herbarium, Biology Department, University of New Brunswick, New Brunswick, Canadá; US - United States National Herbarium, Botany Department, Smithsonian Institution, Washington, U.S.A; R - Herbário, Departamento de Botânica, Museu Nacional do Rio de Janeiro, Universidade Federal do Estado do Rio de Janeiro, Rio de Janeiro, Brasil; RB - Herbário da Seção de Botânica Sistemática do Instituto de Pesquisas Jardim Botânico do Rio de Janeiro, Rio de Janeiro, Brasil; RBR - Herbário, Departamento de Botânica, Universidade Federal Rural do Rio de Janeiro, Seropédica, Itaguaí, Rio de Janeiro, Brasil; RUSU - Herbário da Universidade Santa Úrsula, Rio de Janeiro, Rio de Janeiro, Brasil.

Devido ao grande número de sinônimos existentes, não foi citada a sinonímia para cada táxon, exceto quando se tratava de uma novidade nomenclatural ou de sinônimos recentes.

A terminologia utilizada para a descrição da maior parte dos órgãos foi baseada em revisões e trabalhos atuais sobre a família. A morfologia da folha seguiu Rizzini (1977), o padrão de nervação Hickey (1973) e a caracterização 
das domácias, Santos \& Oliveira (1989) e Santos \&Almeida (1995) indicam, respectivamente, os limites mínimo e máximo encontrados.

As formações vegetais seguem o sistema de classificação de Rizzini (1979). Os dados de distribuição geográfica foram obtidos de literatura e de etiquetas de espécimes herborizados, os fenológicos apenas de coletas realizadas na área, nomes populares e utilidade das espécies através de informações locais ou de literatura especializada.

Os desenhos das folhas foram confeccionados a partir de fotografias obtidas no ampliador fotográfico, onde todas as escalas foram projetadas com o mesmo aumento utilizado para a confecção dos demais desenhos, e os detalhes das estruturas florais e frutíferas foram feitos em microscópio estereoscópico Zeiss, equipado com câmera clara, em diferentes escalas de aumento. Os espécimes fotografados, e que foram aqui utilizados, são provenientes da área estudada e de outras localidades do estado do Rio de Janeiro.

As abreviações utilizadas no texto foram: fl. (flor), fr. (fruto), veg. (vegetativo), s.n. (sem número), s.d. (sem data), s.l. (sem localidade), s.col. (sem coletor), compr. (comprimento), alt. (altura), diâm.(diâmetro), larg. (largura), ms.m (metros sobre o mar), REMC (Reserva Ecológica de Macaé de Cima).

Para a diafanização, fizeram-se algumas adaptações nos métodos de Forster (1974) e de Strittmater (1973). Folhas herborizadas foram postas em solução de hidróxido de sódio a 5\% por 15 a 20 minutos na estufa $\left(\sim 50^{\circ} \mathrm{C}\right)$, o que acelera o processo de diafanização. Posteriormente, foram lavadas em água corrente e colocadas em solução de hipoclorito de sódio a 50\%, até clarificação completa. As folhas foram novamente lavadas em água corrente e colocadas em solução de hidrato de cloral por até 2 horas, sendo então lavadas em água corrente e imersas durante algumas horas em solução diluída de ácido acético. Omaterial foi corado com safranina $0,5 \%$ em solução aquosa e, posteriormente, deixado em álcool a $70 \%$ para retirar o excesso de corante. A seguir, montaram-se as folhas entre lâminas de vidro, utilizando-se glicerina pura como meio de montagem.

\section{RESULTADOS E DISCUSSÃO \\ Descrição da família Lauraceae}

Árvores, arvoretas ou arbustos, raro trepadeiras parasitas (Cassytha), monóicas, dióicas ou gimnodióicas, em geral aromáticas e de casca lisa. Folhas alternas, opostas às subopostas (Beilschmiedia), pecíolos em geral canaliculados, lâmina glabra ou pilosa, indumento com tricomas simples e unicelulares, margem saliente às vezes revoluta, padrão de nervação camptódromo, broquidódromo ou acródromo (Cinnamomum); células oleaginosas e mucilaginosas no mesofilo. Inflorescência ou sinflorescência axilar ou terminal em panícula, tirso, tirsóide ou botrióide. Flores monoclinas ou diclinas, tépalas 6 ou 9 (Phyllostemonodaphne), iguais ou as externas bem menores que as internas (Persea). Androceu 3, 6 ou em geral 9 estames férteis, anteras bilocelares ou quadrilocelares, dispostas em 4 séries: séries I e II com anteras introrsas; série III sempre com par de glândula na base do filete, anteras em geral extrorsas; série IV mais interna, estaminodial ou ausente; quando diclinas as flores masculinas apresentam pistilóide reduzido ou ausente. Gineceu com ovário mediano, súpero, ou ínfero em gêneros não brasileiros, unicarpelar, unilocular, estilete simples, terminal; óvulo único pêndulo, apical ou anátropo; quando diclinas as flores femininas apresentam estaminódios. Fruto com pedicelo frutífero as vezes muito espessado, bacáceo, exocarpo fino, mesocarpo carnoso, pouco ou muito espesso, endocarpo representado apenas pela epiderme interna da parede do fruto; sobre ou parcialmente envolvido pelo hipanto modificado em cúpula, margem simples ou dupla, tépalas persistentes ou decíduas, ou cúpula ausente (Beilschmiedia), ou completamente envolvido na base pelo perigônio acrescente formando uma núcula (Cryptocarya). Semente sem endosperma, embrião desenvolvido, rostelo curto, cotilédones amplos, carnosos. 
Foram registradas, para a Reserva Ecológica de Macaé de Cima, 32 espécies subordinadas a 9 gêneros, a saber: Aniba (1 sp.), Endlicheria (1 sp.), Beilschmiedia (2 spp.), Cryptocarya (2 spp.), Cinnamomum (2 spp.), Persea (2 spp.), Nectandra (3 spp.), Rhodostemonodaphne (1 sp.) e Ocotea (18 spp.).

\section{CHAVE PARA A IDENTIFICAÇÃO DOS GÊNEROS OCORRENTES NA RESERVA ECOLÓGICA DE MACAÉ DE CIMA}

1- Anteras bilocelares

2-Flores diclinas

2. Endlicheria

2'- Flores monoclinas

3 - Folhas opostas a sub-opostas 3. Beilschmiedia

3'- Folhas alternas

4 - Anteras das séries I e II com deiscência introrsa, estaminódios da série IV presentes; lâmina foliar com a epiderme abaxial em geral sem papilas 4. Cryptocarya 4- Anteras das séries I e II com deiscência extrorso-apical, estaminódios da série IV ausentes; lâmina foliar em geral com a epiderme abaxial com papilas 1. Aniba

1'- Anteras quadrilocelares

5- Estaminódios da série IV sagitados

6 - Tépalas externas e internas iguais; filetes menores que as anteras; folhas com padrão de nervação acródromo-broquidódromo ou camptódromo-broquidódromo 5. Cinnaтотит

6'- Tépalas externas geralmente menores que as internas; filetes maiores que as anteras; folhas com padrão de nervação eucamptódromo ou camptódromo-broquidódromo

6. Persea

5' - Estaminódios da série IV filiformes ou ausentes.

7- Anteras com locelos dispostos em arco 7. Nectandra

7'- Anteras com locelos dispostos em pares superpostos ou em linhas horizontais 8 - Anteras com locelos dispostos em linhas horizontais _ 8. Rhodostemonodaphne 8 ' - Anteras com locelos dispostos em pares superpostos 9. Ocotea

\section{Descrições, chaves e comentários dos táxons ocorrentes na Reserva Ecológica de Macaé de Cima}

\section{Aniba Aubl.}

Árvores ou arvoretas, monóicas. Folhas alternas, padrão de nervação broquidódromo, em geral, com papilas na epiderme abaxial. Inflorescência em panícula ou botrióide. Flores monoclinas, tépalas 6, iguais. Androceu com 9 estames férteis, anteras bilocelares: séries I e
II com 3 estames cada, anteras introrsas; série III com 3 estames, um par de glândula na base dos filetes, anteras extrosas; série IV estaminodial ausente ou raro 3 estaminódios filiformes. Gineceu com ovário elipsóide ou ovóide, incluso no tubo do perigônio. Fruto bacáceo, elipsóide ou ovóide, envolvido parcialmente por cúpula hemisférica, lenhosa, tépalas decíduas.

Aniba apresenta cerca de 41 espécies, distribuídas na América Central, Antilhas e principalmente na América do Sul. A concen- 
tração do maior número de espécies encontrase na região das Guianas e Amazônia Central (Kubitzki \& Renner, 1982). No Brasil, o gênero é representado por 25 espécies, das quais duas ocorrem no estado do Rio de Janeiro. Na REMC, foi coletada apenas $A$. firmula (Nees et Mart.) Mez.

Kostermans (1957) posiciona o gênero na subtribo Anibineae, junto com Endlicheria, Aiouea e Licaria, considerando o primeiro mais próximo de Aniba, sendo distinto por apresentar flores diclinas e anteras com células mais largas.

Kubitzki \& Renner (1982), na mais recente revisão de Aniba, consideram Licaria o gênero mais próximo por compartilharem caracteres exclusivos a estes dois gêneros, como forma dos estames, pistilo delgado e tamanho proporcional do hipanto em relação ao fruto. Reconhecem, ainda, a subdivisão do gênero em seis grupos distintos, com base na forma dos estames, abertura e direção dos locelos, estrutura das projeções papilosas da epiderme das folhas e por caracteres fitoquímicos.

Richter (1981), através de estudos de anatomia do lenho associado aos tipos de inflorescência, evidencia semelhanças entre Aniba, Licaria e Ocotea.

Aniba firmula (Nees \& Mart. ) Mez, Jahrb. Königl.Bot.Gart.Berlin 5:57.1889.

Figuras 2: A1-A8

Árvore de 6 a $18 \mathrm{~m}$ alt., tronco de casca lisa, ramos angulosos. Folhas com pecíolo canaliculado, estriado; lâmina cartácea, lanceolada a largo-lanceolada, 12,0-26,0 ×3,5-6,2 cm, glabrescente, base aguda, margem espessa, ápice acuminado; face abaxial inteiramente papilosa; nervura principal impressa na face adaxial e proeminente na face abaxial; padrão de nervação broquidódromo, nervuras secundárias 8 - 13 pares alternos, ângulo de divergência de ca. $45^{\circ}$, nervuras intersecundárias compostas, reticulado denso. Inflorescência axilar, panícula, 2,5 -5,5 cm compr., alva ou áureo-tomentosa. Flores amarelas, tépalas ovadas, 0,11 0,14 cm compr., margem ciliada, ápice obtuso, amarelas, tomentosas na face ventral. Estames da série I e II com filetes denso-vilosos, mais largos que anteras, com locelos extrorsos-apicais; estames da série I com filetes denso-vilosos, anteras triangulares, $0,08-0,11 \mathrm{~cm}$ compr.; série II filetes denso-vilosos, anteras estreitadas, 0,09-0,12 cm compr.; série III filetes delgados, vilosos, par de glândula globosa na base, anteras ovadas 0,12 - 0,14 cm compr.; série IV estaminodial ausente. Ovário elipsóide, base áureo-pubérula, estilete delgado, estigma oblíquo. Fruto elipsóide, 2,8 -3,3 x 1,1 - 1,8 cm, envolvido parcialmente por cúpula hemisférica, 2,0-2,8 x 2,0-2,5 cm compr., lenhosa, verrucosa; pedicelo frutífero espesso.

Nomes populares: Canela-rosa, canelasassafrás.

Floração e frutificação: Coletada com flores em junho e outubro, com frutos em fevereiro, abril, julho e agosto.

Habitat: Ocorre na Floresta Pluvial Atlântica Baixo-montana e Montana, Floresta Seca e matas de Restinga.

Distribuição geográfica: No Brasil, nos estados da Bahia, Espírito Santo (Nicolau, 1999), Minas Gerais, Paraná, Rio de Janeiro, Rio Grande do Sul (Nicolau, 1999), Santa Catarina e São Paulo.

Material examinado: Coleção REMC: Sítio Fazenda Velha, rio Macaé, 13/08/1990 (veg.), C.M.B. Correia et al. s.n. (RB 292590); Ibidem, 16/08/90 (veg.), J.F. Baumgratz et al. s.n (RB 292389); Ibidem, 30/09/90 (veg.), H.C. Lima et al. s.n. (RB 328532).

Material adicional selecionado: Brasil: Bahia: Ilhéus, fazenda Pirataguissé, 29/03/ 1944 (fl), H.P. Vellozo 743 (R). Minas Gerais: Viçosa, E.S.A.V., 24/12/1934 (fl.), J.G. Kuhlmann 5129 (RB); Diamantina, estrada para Mendanha a $15 \mathrm{~km}$ de Diamantina, $18^{\circ} 07^{\prime}$ S e 43'30' W, 31/10/1988 (fl.), R.M. Harley et al. 25469 (RB); Alfenas, Fazenda Ilha, 29/10/ 1990 (fl.), T. Cristina s.n. (RB 202710). Paraná: São José dos Pinhais, 30/12/1975 (fl.), H.G. Richter 53 (RB, BFA). Rio de Janeiro: Rio de Janeiro, Vista Chineza, 11/01/1962 (fl.), A.P. Duarte 6219 (RB); Ibidem, São Conrado, 07/ 


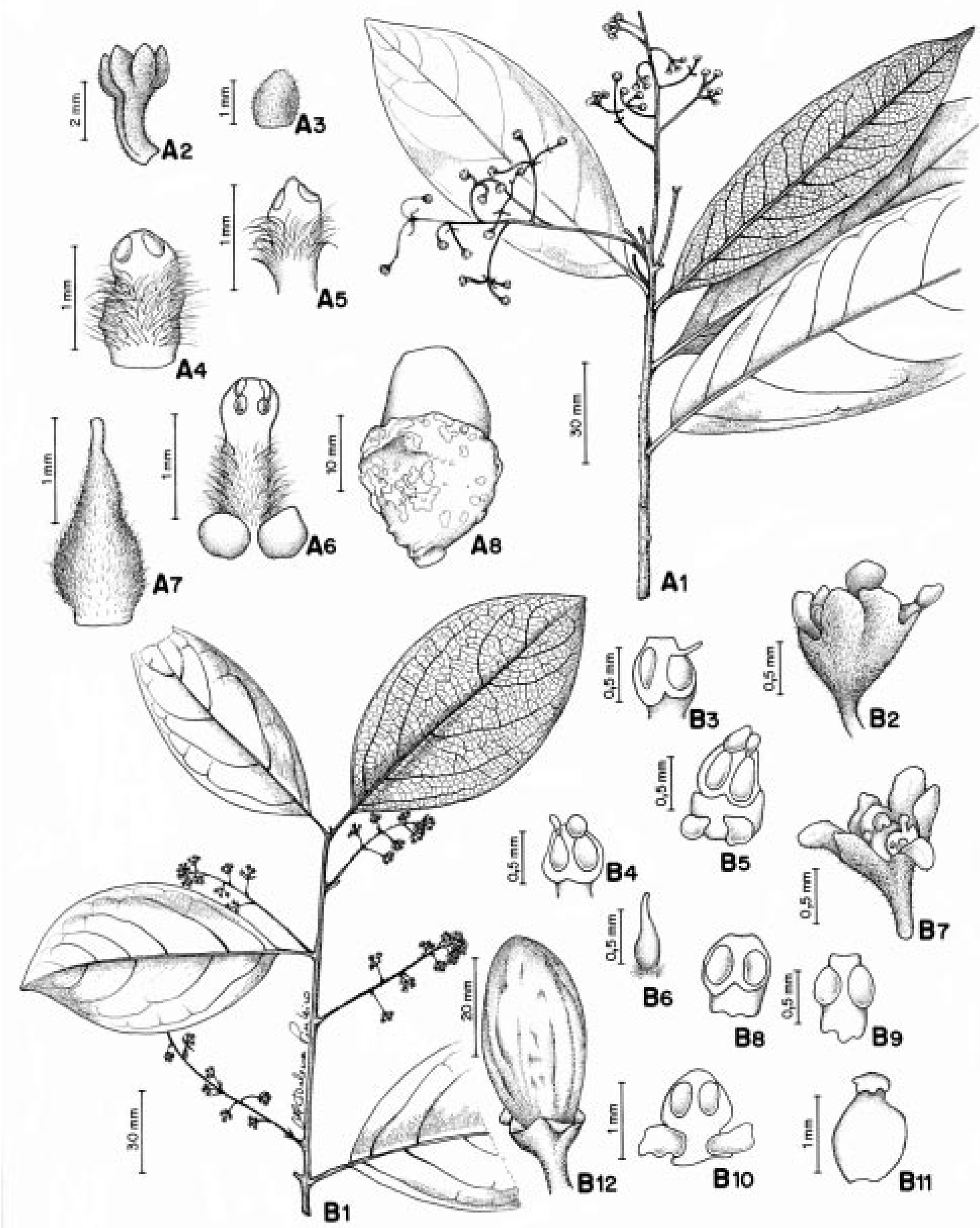

Figura 2 - A. Aniba firmula (Nees \& Mart.) Mez: A1 - Ramo florífero; A2 - Flor; A3 - Tépala; A4 - Estame da série I; A5 - Estame da série II; A6 - Estame da série III; A7 - Gineceu; A8 - Fruto.B. Endlicheria paniculata (Spreng.) J.F. Macbr.: B1 - Ramo florífero; B2 - Flor masculina; B3 - Estame da série I; B4 - Estame da série II; B5 - Estame da série III; B6 - Pistilóide; B7 - Flor feminina; B8 - Estaminódio da série I; B9 - Estaminódio da série II; B10 - Estaminódio da série III; B11 - Gineceu; B12 - Fruto. (A1-A7, T. Cristina s.n. (RB 202710); A8, O.C. Góes \& Dionísio 255; B1-B6, B.C. Kurtz 80; B7-B12, B.C. Kurtz 87). 
03/1961 (fl.), A.P. Duarte 5516 (RB, M); Petrópolis, Carangola, 03/07/1943 (fr.), O.C. Góes et E. Dionísio 255 (RB). Santa Catarina: Florianópolis, Morro do Ribeirão, 16/ 01/1967 (fl.), R.M. Klein 7082 (FLOR, RB); Matador, Rio do Sul, 27/06/1963 (fr.), R. Reitz et R.M. Klein 8881 (RB, FLOR). São Paulo: Ilha da Cocainha, 1951 (fr.), J. Cappell s.n. (RB 113561); Mogi das Cruzes, 20/04/1889 (fr.), C.A. Schwacke 6608 (RB).

Comentários: Aniba firmula é registrada desde o Sul da Bahia até o Rio Grande do Sul e habita áreas em estádio sucessional secundário, podendo também fazer parte do componente do dossel em áreas mais preservadas. Ocupa preferencialmente as Florestas Pluvial Atlântica Montana e Baixo-montana, ou ainda a Floresta Seca de Minas Gerais, sendo pouco expressiva em áreas de Restinga do estado do Rio de Janeiro. É freqüente na Reserva Ecológica de Macaé de Cima, onde se caracteriza por ser uma espécie heliófila e pioneira, principalmente em formações secundárias.

Pode ser facilmente identificada pelo odor adocicado característico, presença de papilas na face abaxial das folhas, flores amarelas, monoclinas, perigônio ereto após a antese, anteras bilocelares e filetes denso-vilosos.

Foi utilizado, para complementar a descrição, o material em flor de T. Cristina s.n. (RB 202710) e, em fruto, de O.C. Góes \& Dionísio 255 (RB).

\section{Endlicheria Nees}

Árvores dióicas: Folhas alternas, sem papilas na epiderme abaxial. Inflorescência em panícula ou tirsóide. Flores diclinas, tépalas 6 , iguais. Flores masculinas: androceu com 9 estames férteis, anteras bilocelares: as das séries I e II com 3 estames cada, anteras introrsas; série III com 3 estames, par de glândula na base dos filetes, anteras extrorsas ou lateralmente extrorsas; série IV estaminodial ausente; pistilóide presente ou ausente. Flores femininas: estaminódios reduzidos, de morfologia semelhante aos estames das flores masculinas; ovário elipsóide ou subgloboso, estilete em geral curto. Fruto bacáceo, elipsóide, cúpula rasa, tépalas decíduas raro persistentes.

Endlicheria tem cerca de 40 espécies distribuídas na Ámerica Tropical (Kostermans, 1937; Rohwer, 1993b). No estado do Rio de Janeiro, segundo Vattimo-Gil (1996), ocorrem três espécies e na REMC foi coletada apenas E. paniculata (Spreng.) J. F. Macbr..

Kostermans (1957) posiciona o gênero Endlicheria na subtribo Anibinae, juntamente com os gêneros Aiouea, Aniba, Licaria, Systemonodaphne e Urbanodendron.

Rohwer (1993b) acredita que Endlicheria seja um gênero polifilético próximo de Ocotea e Rhodostemonodaphne.

Endlicheria paniculata (Spreng.) J.F. Macbr., Field. Mus. Nat. Hist. (13) 2: 850.1938 .

Figuras 2: B1-B12

Árvores de $5 \mathrm{a} 7 \mathrm{~m}$ alt., tronco de casca lisa, verde-acinzentada, ramos áureo- tomentosos; gemas axilares e terminais áureo-tomentosas. Folhas com pecíolo canaliculado, pubescente; lâmina cartácea, lanceolada a elíptica, 6,5 -10,6 x 2,4-4,7 cm, base cuneada, margem espessa, ápice agudo a curto-acuminado, face adaxial pubescente na nervura principal, face abaxial áureovelutina; nervura principal impressa na face adaxial, proeminente na face abaxial; padrão de nervação eucamptódromo, nervuras secundárias 5-6 pares alternos, ângulo de divergência $30^{\circ}-50^{\circ}$, nervuras intersecundárias compostas, nervuras terciárias partem perpendicularmente da nervura primária e ramificam-se antes de se fundirem com as secundárias, reticulado denso. Inflorescência axilar, tirsóide, 3,0 - 12,0 cm compr., áureo-velutina, feminina multiflora e masculina pauciflora. Flores com tépalas iguais, obovadas, 0,08-0,1 cm compr., áureo-velutinas; hipanto na face ventral áureo-seríceo. Flores masculinas: estames da série I com filetes curtos, $0,01-0,03 \mathrm{~cm}$, anteras ovais, $0,05-0,07 \mathrm{~cm}$ compr., ápice truncado, introrsas; estames da série II com filetes curtos, $0,02-0,03 \mathrm{~cm}$ compr., anteras semelhantes às da série I, $0,04-0,07 \mathrm{~cm}$ 
compr.; estames da série III com filetes largos quanto as anteras, 0,02 - 0,03 cm compr., par de glândula globosa na base, anteras ovais, 0,1 0,11 cm compr., ápice obtuso; série IV estaminodial ausente; pistilóide presente, filiforme. Flores femininas: androceu com estaminódios reduzidos, semelhantes às anteras das flores masculinas; ovário ovóide, glabro, estilete curto, espessado, estígma sub-trigono. Fruto elipsóide, 1,5 - 1,2 cm compr. x 0,8 - 0,9 cm diâm., verde, sobre cúpula hemisférica, $0,4-0,5 \mathrm{~cm}$ compr. $\mathrm{x}$ 0,6 - 0,7 cm diâm., rubra, tépalas persistentes ou decíduas; pedicelo frutífero obcônico.

Nomes populares: Canela-do-brejo, canelapreta.

Usos: Fornece madeira branca de ótima qualidade, própria para construção civil e taboado; a casca e as folhas são aromáticas e adstringentes (Corrêa, 1926).

Floração e frutificação: Coletada com flores em novembro e dezembro, com frutos em janeiro e fevereiro.

Habitat: No Brasil, ocorre na Floresta Pluvial Amazônica, Floresta Pluvial Atlântica Montana e Baixo-montana, Floresta Seca e Cerrado.

Distribuição geográfica: No Brasil, nos estados do Amapá, Bahia, Distrito Federal, Espírito Santo, Goiás, Mato Grosso do Sul, Minas Gerais, Paraná, Rio de Janeiro, Rio Grande do Sul, Santa Catarina e São Paulo. Colômbia, Equador, Panamá, Paraguai e Peru.

Material examinado: Coleção da REMC: Proximidades do rio Macaé, 8/12/1989 (fl. fem.), B.C. Kurtz 80 (RB); Nascente do Rio das Flores, 8/12/1989 (fr.), B.C. Kurtz 87 (RB); Sítio Sophronites, 29/12/1989 (fl.), $M$. Nadruz 573 (RB).

Material adicional selecionado: Brasil: Distrito Federal: Brasília, Fundação Zoobotânica, 04/04/1963 (fl.), E.P. Heringer 9316 (HB). Espírito Santo: Santa Tereza, 25/02/ 1965 (fl.), E. Pereira 9837 (RB, HBG). Goiás: s.1., s.d., A.F.M. Glaziou 22056 (RB); Serra Geral do Paraná, $3 \mathrm{~km}$ ao sul da rodovia São João da Aliança, 23/03/1973 (fl.), W.R. Anderson 7759 (RB, NYBG). Mato Grosso do Sul: Próximo ao rio Brilhante, 02/09/1980 (fr.), J.G. Guimarães 1139 (RB, HRB). Minas Gerais: Ouro Preto, Estação Ecológica do Tripuí, estrada do Tripuí, 18/11/1994 (fl.), Meyer et al. s.n. (HB 81.887). Paraná: Guaratuba, Rio Divisa, 06/11/1960 (fr.), G. Hatschbach s.n. (RB 108726); Paranaguá, rio Cambará, 24/10/1968 (fr.), G. Hatschbach s.n. (RB 175218). Rio de Janeiro: Rio de Janeiro, Horto Florestal, trilha do arranha gato, acima da represa da Cedae, 02/02/1996 (fl.masc.), A. Quinet et al. 59 (RB); Ibidem, Alto da Boa Vista, Açude Solidão, 6/01/1944 (fl.), M.H. Vale 86 (R). Santa Catarina: Itajaí, Cunhas, 08/02/1955 (fl.), R. Klein 1127 (RB, FLOR); Bom Retiro, Paulo Lopes, 24/08/1973 (fr.), A. Bresolin 814 (RB, FLOR). São Paulo: São Vicente, Praia Grande, 11/01/1964 (fl.), E. Pereira 8156 \& G. Pabst 7431 (HB, HBG, RB); Jaguariuçuna, 22/08/1968 (fr.), H.F. Leitão Filho 496 (RB).

Paraguai: Bossero Villar, FINAP, 15/02/1971 (fl.), R.M. Klein et J. A. Lopes 9337 (RB).

Comentários: Endlicheria paniculata ocorre desde o Panamá na América Central e na América do Sul, na Colômbia, Peru, Equador e Paraguai. No Brasil, está representada nas quatro regiões tendo seu limite norte no Amapá e o sul no Rio Grande do Sul. Trata-se de uma espécie seletiva higrófila, que habita locais na beira ou próximo a córregos e rios e sua ampla distribuição poderia ser explicada por migração via florestas ciliares. Na Reserva, foram coletados três indivíduos em área perturbada e três em área preservada, onde demonstrou preferência por ambientes úmidos e sombrios, ocorrendo, entretanto, como heliófila na borda do rio.

É uma planta aromática e caracterizase pela lâmina foliar em geral pilosa, padrão de nervação eucamptódromo, flores diclinas, anteras bilocelares, frutos elipsóides, parcialmente envolvidos por cúpula rubra com tépalas persistentes ou decíduas. Apresenta heterofilia acentuada, folhas em geral variando de cartáceas e pilosas a coriáceas e glabrescentes. 


\section{Beilschmiedia Nees}

Árvores monóicas. Folhas opostas a subopostas, sem papilas na epiderme abaxial. Inflorescência em panícula ou tirsóide. Flores monoclinas, sésseis ou raro pediceladas, tépalas 6, iguais. Androceu com 9 estames férteis, anteras bilocelares: séries I e II com 3 estames cada, anteras introrsas; série III com 3 estames, par de glândula na base do filete, anteras extrorsas; série IV estaminodial ausente ou presente com 3 estaminódios sagitados. Gineceu com ovário em geral pubescente. Fruto bacáceo, elipsóide ou esférico, cúpula ausente.

Beilschmiedia compreende cerca de 250 espécies (Nishida, 1999), de distribuição pantropical, na África, Ásia, Malásia, Austrália, Ilhas do Pacífico, Nova Zelândia, América Central e América do Sul (Rohwer, 1993b). Nos neotrópicos, engloba 28 táxons (Nishida, 1999). No Brasil ocorrem, de forma disjunta, uma espécie na região Amazônica e sete na região Sudeste (Araújo, 1994). O grupo do Sudeste caracteriza-se pelas folhas opostas e anteras pubescentes no ápice. Na REMC, são reconhecidas $B$. rigida $(\mathrm{Mez})$ Kosterm. e $B$. fluminensis Kosterm.

Nishida (1999), na revisão do gênero, reconhece cinco grupos, com base na filotaxia, padrão de nervação, arranjo dos feixes vasculares, cutícula e na distribuição geográfica. As espécies da Reserva pertencem ao grupo de B. curviramea, que é caracterizado pelas folhas opostas e anteras pubescentes no ápice e estão restritas ao sudeste do Brasil.

\section{CHAVE PARA IDENTIFICAÇÃO DAS ESPÉCIES DE BEILSCHMIEDIA}

1 - Lâmina elíptica ou oboval, ápice em geral emarginado, às vezes obtuso ou agudo; fruto com epicarpo lenticelado, sem máculas ferrugíneas 1. B. rigida

1'- Lâmina lanceolada a elíptico-lanceolada, ápice agudo; fruto com epicarpo não lenticelado, com máculas ferrugíneas 2. B. fluminensis

Beilschmiedia rigida (Mez) Kosterm., Rec. Trav. Bot. Néerl.35: 856. 1938.

Figura 3: A1-A9

Árvore 17 - $30 \mathrm{~m}$ de alt., tronco de casca rugosa, fissurada, ramos angulosos, ásperos, sulcados, amarronzados, alvo-tomentosos. Folhas com pecíolo achatado, estriado; lâmina coriácea, elíptica ou obovada, $6,0-17,0 \times 2,8-8,4 \mathrm{~cm}$, base aguda, decorrente, margem espessa, revoluta, ápice em geral emarginado, obtuso ou raro agudo, face adaxial glabra e face abaxial áureahispida; nervura principal impressa na face adaxial, proeminente na face abaxial; padrão de nervação broquidódromo, nervuras secundárias proeminentes em ambas as faces, 7 - 10 pares alternos, ângulo de divergência ca. $45^{\circ}$, nervuras inter-secundárias compostas, reticulado laxo. Inflorescência axilar, panícula. Flores com tépalas sub-globosas 1,0 - 1,2 cm compr., alvo a áureo tomentosas em ambas as faces, cônca- vas. Estames das séries I, II, III sub-sésseis, anteras das séries I e II ovais, 0,12-0,15 cm compr, ápice obtuso a truncado, denso alvo-pilosas, margem ciliada; série III anteras ovais a sub-retangulares, 0,12- 0,13 mm compr., ápice truncado ou obtuso, pilosas na face dorsal e nas margens; série IV estaminodial presente, estaminódios triangulares, 0,075 - 0,1 cm compr., ápice agudo, pubescente na face dorsal e ápice. Ovário elipsóide, sub-glabro, estilete obcônico, estígma capitado. Fruto elipsóide, 3,2 -4,0 x 1,5-1,8 cm, base aguda, ápice obtuso, epicarpo lenticelado, rugoso, sem máculas ferrugíneas; pedicelo frutífero subcilíndrico a anguloso, estriado.

Nome popular: Canela-tapinha.

Floração e frutificação: Coletada com flores em setembro, com frutos em maio.

Habitat: Ocorre na Floresta Pluvial Atlântica Montana.

Distribuição geográfica: No Brasil, nos esta- 


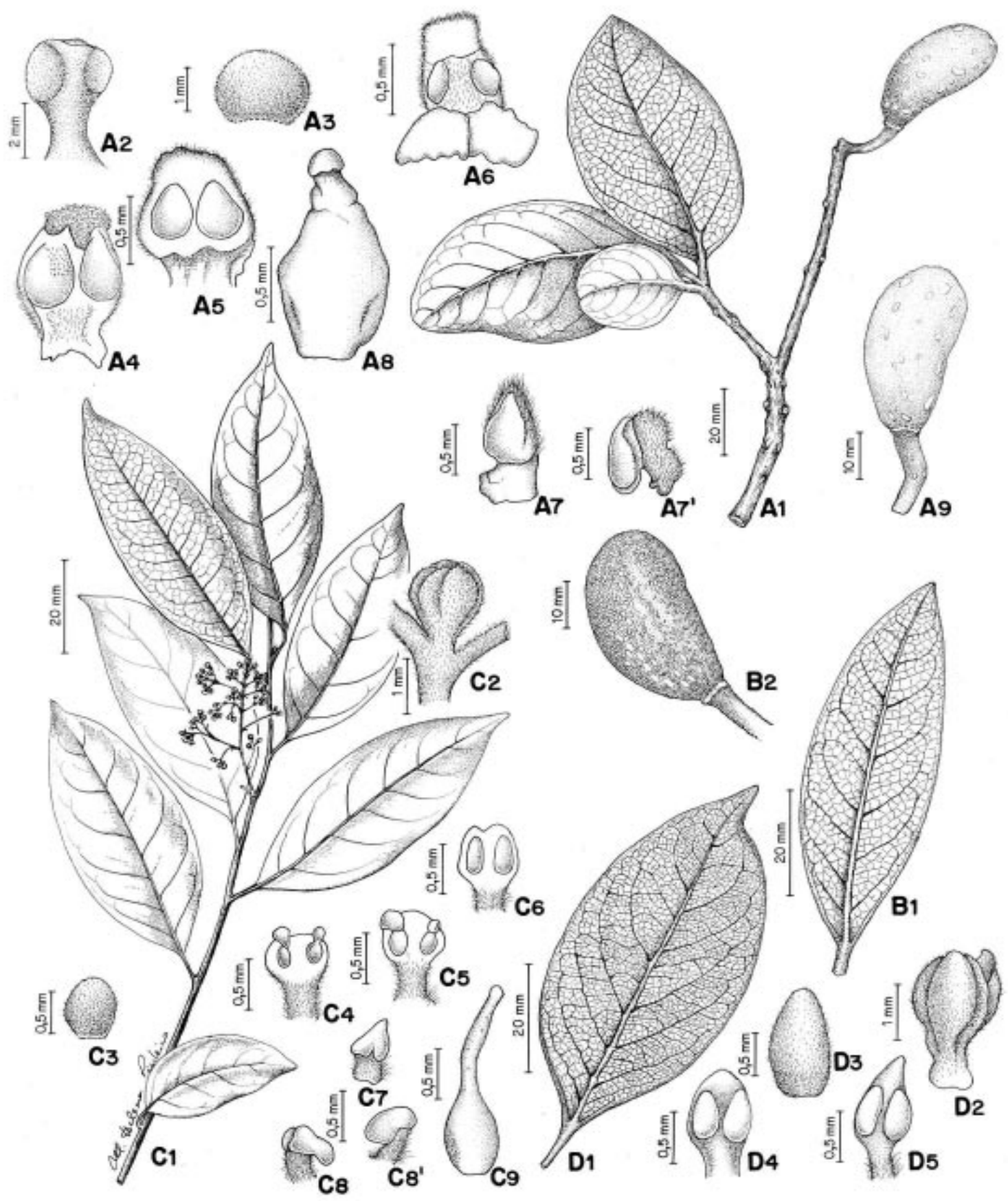

Figura 3 - A. Beilschmiedia rigida (Mez) Kosterm.: A1 - Ramo frutífero; A2 - Botão floral; A3 - Tépala; A4 - Estame da série I; A5 - Estame da série II; A6 - Estame da série III; A7 - Estaminódio da série IV, vistas frontal e lateral, respectivamente; A8 - Gineceu; A9 - Fruto. B. Beilschmiedia fluminensis Kosterm.: B1 - Folha; B2 - Fruto; C. Cryptocarya micrantha Meisn.: C1 - Ramo florífero; C2 - Flor; C3 - Tépala; C4 - Estame da série I; C5 - Estame da série II; C6 Estame da série III; C7 - Estaminódio da série IV; C8-C8' - Glândula, vistas dorsal e lateral, respectivamente; C9 Gineceu. D. Cryptocarya moschata Nees \& Mart. ex Nees: D1 - Folha; D2 - Flor; D3 - Tépala; D4 - Estame da série I; D5 - Estame da série II. (A1-A8, H. C. Lima 3707; A9, G. Martinelli 12889; B1-B2, G. Martinelli 11917; C1-C9, Schwacke 6680; D1-D2, I.A. Araujo 107). 
dos do Espírito Santo (Nishida, 1999), Rio de Janeiro.

Material examinado: Coleção REMC: Nascente do Rio das Flores, 12/05/88 (fr.), G. Martinelli 12889 (RB); Estrada para sítio Sophronites, 14/ 09/ 89 (fl.), H.C. Lima 3707 (RB). Comentários: Beilschimiedia rigida era conhecida apenas pelo material-tipo coletado por Glaziou em Macaé de Cima. Foi recoletada em áreas preservadas da Reserva, sendo uma das espécies mais frequëntes, com espécimes que ocupam o estrato arbóreo superior e destacam-se entre as emergentes. Espécie exclusiva da Floresta Pluvial Atlântica Montana.

Distingue-se das demais do grupo $B$. curviramea por suas folhas com pecíolos longos, ápice arredondado, flores e raque da inflorescência mais espessas.

Beilschmiedia fluminensis Kosterm., Rec. Trav. Bot. Nèerl. 35: 865.1938.

Figura 3: B1-B2

Árvore com 12 m alt., ramos subcilíndricos a angulosos no ápice, glabros, lenticelados; gemas apicais e axilares áureo-pubescentes. Folhas com pecíolo canaliculado, não estriado; lâmina cartácea a coriácea, lanceolada a elíptico-lanceolada, 4,7-9,0 x 1,8-3,8 cm, base aguda, margem sub-revoluta, ápice agudo, face adaxial glabra, face abaxial áureo-tomentosa; nervura principal impressa na face adaxial, proeminente na face abaxial no terço inferior, atenuando em direção ao ápice; padrão de nervação broquidódromo, nervuras secundárias 7 9 pares alternos, ângulo de divergência ca. $45^{\circ}$, nervuras inter-secundárias compostas, reticulado laxo. Inflorescência axilar, panícula, 2,5 - 7,7 cm compr., áureo-tomentosa. Flores com tépalas elípticas ou ovais, 1,0 -1,2 mm de compr., côncavas, pubescentes na face ventral e dorsal, margem ciliada. Estames das séries I, II, III com filetes menores que as anteras; série I com antera oval, 0,07-0,08cm compr., ápice obtuso a truncado, pubescente na face dorsal, margem ciliada; série II com antera estreitada, oval, 0,6-0,7 mm compr., ápice obtuso, pubescente, margem ciliada; série III filete com par de glândula na base, antera sub-cilíndrica a retangular, $0,1-0,11 \mathrm{~cm}$ compr., ápice obtuso, pubescente, margem ciliada; série IV estaminodial presente, estaminódios cordiformes, com resquício locelar, face dorsal e ápices pubescentes. Ovário elipsóide, $0,11 \mathrm{~cm}$ compr., glabro, estilete obcônico, estígma obtuso. Fruto elipsóide, 3,0-4,8 x 1,9-3,2 cm compr., epicarpo não lenticelado, rugoso, com máculas ferrugíneas; pedicelo frutífero cônico.

Floração e frutificação: Coletada com flores em novembro, com frutos em abril, agosto e novembro.

Habitat: Ocorre na Floresta Pluvial Atlântica Baixo-montana, Montana e de transição para nebular.

Distribuição geográfica: No Brasil, nos estados de Minas Gerais (Nishida, 1999), Espírito Santo e Rio de Janeiro.

Material examinado: Coleção da REMC: Nascente do Rio das Flores, 26/11/1986 (fr.), G. Martinelli 11917 (RB); Sítio Bacchus, 03/04/88 (fl.), I. Araujo 18 (RB); Trilha da Serra dos Piri-neus, 16/08/89 (fr.), I. Araujo 51 (RB).

Material adicional selecionado: Brasil: Espírito Santo: Colatina, margem do rio Pancas, estrada da colônia, 02/05/1934 (fr.), J.G. Kulhmann 292 (RB). Rio de Janeiro: Rio de Janeiro, Mato Escuro, obras públicas, 21/10/1927 (fl.), Antenor s.n. (RB 102163); Ibidem, Silvestre, 02/09/1959 (fl.), A.P. Duarte 5007 (RB); Ibidem, Floresta da Tijuca, caminho para a mata do Pai Ricardo, 26/07/ 1973 (fl.), D. Sucre et al. 10058 (RB, GUA); Miguel Pereira, Governador Portela, Monte Sinai, 1935 (fl.), G.M. Nunes 323 (RB).

Comentários: Beilschmiedia fluminensis é considerada por Kostermans (1938b) como afim de B. emarginata, diferindo desta pelo comprimento do pecíolo, forma da folha e nervação foliar mais densa. Conhecida anteriormente apenas pelo exemplar-tipo, coletado por Glaziou em Governador Portela, município de Miguel Pereira, estado do Rio de Janeiro. Nishida (1999), na revisão do gênero, cita 
outras duas coletas para o estado do Rio de Janeiro e Minas Gerais e afirma que as coleções de B. fluminensis são de difícil separação das de B. taubertiana e B. emarginata. Segundo o autor, $B$. fluminensis pode ser separada destas pelas gemas terminais e botões florais adpresso-pubescentes e pelo pecíolo relativamente maior. Em B. taubertiana, os pêlos são eretos e longos, enquanto em $B$. emarginata são eretos, curtos e ondulados e ambas as espécies apresentam pecíolo mais curto. $\mathrm{O}$ autor comenta ainda que $B$. stricta tem grande afinidade com B. fluminensis, ambas apresentando o mesmo tipo de indumento, forma da folha e estrutura floral, diferenciando-se pela base da lâmina levemente revoluta em $B$. stricta e pela inflorescência pubescente.

Com distribuição geográfica restrita à região sudeste, apresenta seu limite mais ao norte no estado do Espírito Santo, e o limite mais ao sul no estado do Rio de Janeiro, habitando exclusivamente a Floresta Pluvial Atlântico Montana e Baixo-montana.

Cryptocarya R. Br.

Árvores monóicas. Folhas alternas, em geral, sem papilas na epiderme abaxial. Inflorescência em panícula ou tirsóide. Flores monoclinas, tépalas 6, iguais. Androceu com 9 estames férteis, anteras bilocelares; filetes maiores que as anteras: séries I e II com 3 estames cada, anteras introrsas; série III com 3 estames, glândulas na base dos filetes ou dis- postas entre séries I, II e III de estames, anteras extrorsas; série IV estaminodial presente, com 3 estaminódios, em geral sagitados. Gineceu com ovário glabro, elipsóide ou ovóide. Fruto constituído por uma núcula globosa, pericarpo espessado, consistência firme, superfície lisa ou estriada; hipanto acrescente, consistência carnosa, superfície lisa ou sulcada, que envolve completamente a núcula. No ápice umbonado do fruto, a margem do hipanto e estames são geralmente persistentes.

Cryptocarya apresenta cerca de 350 espécies de distribuição pantropical, cujo centro de distribuição está localizado na Malásia, não havendo registros na África (Rohwer, 1993b). O nome genérico Cryptocarya é derivado do grego: Kripton (escondido) e Karyon (noz), pois o fruto é envolvido pelo tubo do perigônio acrescente (Vattimo-Gil, 1966b).

Kostermans (1937), na revisão das espécies americanas do gênero, reconhece três subgêneros, e inclui as espécies brasileiras no subgênero Cryptocarya, cuja característica principal é a presença de nove estames férteis. $\mathrm{O}$ autor ainda atribui, com base em caracteres florais, a proximidade de Cryptocarya com Beilschmiedia.

Segundo Coe-Teixeira (1965) e VattimoGil (1959a, 1966b), são reconhecidas oito espécies para a região sudeste do Brasil. Para REMC, foram encontradas Cryptocarya moschata Nees \& Martius ex Nees e Cryptocarya micrantha Meisner.

\section{CHAVE PARA IDENTIFICAÇÃO DAS ESPÉCIES DE CRYPTOCARYA}

1- Lâmina coriácea, face abaxial papilosa, padrão de nervação eucamptódromo; tépalas lanceoladas, ápice agudo, de tamanho semelhante ao hipanto comprimido; anteras das séries I e II com ápice agudo

1. C. moschata

1'- Lâmina cartácea, face abaxial sem papilosidade, padrão de nervação broquidódromo; tépalas ovais, ápice obtuso, de tamanho menor que o hipanto urceolado; anteras das séries I e II com ápice obtuso ou truncado 2. C. micrantha 
Cryptocarya moschata Nees \& Mart. ex Nees, Linnaea 8:37.1833.

Figura 3: D1-D5

Árvore de 8 - $18 \mathrm{~m}$ de alt., tronco de casca delgada ramos subcilíndricos, marrons, ásperos, lenticelados, glabrescentes; gemas apicais áureo-tomentosas. Folhas com pecíolo sub-cilíndrico, levemente canaliculado, com estrias horizontais, às vezes lenticelado; lâmina coriácea, elíptica, 8,5 - 16,0 × 4,0 - 7,4 cm, base cuneada, margem revoluta, ápice agudo a acuminado, face abaxial papilosa e levemente áureo-tomentosa; nervura principal impressa na face adaxial e proeminente na abaxial; padrão de nervação eucamptódromo, nervuras secundárias 5-8 pares alternos a sub-opostos, ângulo de divergência $40^{\circ}-45^{\circ}$, nervação marginal em arcos resultantes das ramificações das nervuras secundárias, nervuras inter-secundárias compostas, reticulado denso. Inflorescência axilar ou subterminal, tirsóide, 2,5-9,5 cm compr. Flores com tépalas lanceoladas, 0,08-0,1 cm compr., ápice agudo, áureo-tomentosa nas faces ventral e dorsal, de tamanho semelhante ao hipanto comprimido. Estames das séries I e II com filetes delgados, 0,04-0,05 cm compr., pilosos, anteras ovado-triangulares, 0,06-0,07 cm compr., glabrescentes, ápice agudo; par de glândulas globosas, estipitadas, dispostas entre as séries I, II e III de estames; estames da série III com filetes delgados, 0,05-0,06 cm compr., pilosos, anteras ovais, 0,06-0,07 cm de compr., ápice agudo, lateralmente extrorsas; série IV estaminodial, 0,09-0,1 cm de compr., estaminódios sagitados, densamente pilosos nas faces ventral e dorsal. Ovário elipsóide, estilete cilíndrico, delgado, estígma discóide. Fruto obovóide a piriforme, 1,2-2,5 cm x 0,5-1,5 cm, costulado, totalmente incluso no hipanto acrescente, tépalas persistentes no ápice ou decíduas.

Nome popular: Noz-moscada.

Floração e frutificação: Coletada com flores em julho, agosto, outubro, com frutos em fevereiro e outubro.

Habitat: Ocorre na Floresta Pluvial Atlântica Baixo-montana e Montana, Floresta Seca.

Distribuição geográfica: No Brasil, nos es- tados de Minas Gerais, Paraná, Pernambuco, Rio de Janeiro, Santa Catarina e São Paulo.

Material examinado: Coleção REMC: Estrada para sítio Sophronites, 13/09/1988, H.C. Lima 3691 (RB, SPSF, MO, NY); Sítio Sophronites, 26/10/1989 (fl.), I.A. Araujo 107 (RB).

Material adicional selecionado: Brasil: s.l., s.d. (fl.), Sellow s.n. (K). Minas Gerais: Carangola, fazenda Santa Rita, 11/08/1992 (fr.), S. Leone 1905 (HB); Barbacena, 04/11/1928 (fl.), s.col. (RB 110592). Paraná: Guaratuba, Serra do Araraguara, Morro do Cauvi, 25/03/ 1965 (fr.), G. Hatschbach s.n. (RB 130397). Pernambuco: Alagoas, s.d. (veg.), A.M. Uchôa 15 (RB). Rio de Janeiro: s.d. (fl.), Riedel 485 (K); Rio de Janeiro, Vista Chinesa, 03/1962 (fl.), A.P. Duarte 7991 (RB); Teresópolis, Parque Nacional da Serra dos Órgaos, 1942 (fr.), $E$. Dionísio et Otávio s.n. (RB 125772). Santa Catarina: Ibirama, posto indígena, 31/01/1976 (veg.), H.G. Hichter 93 (RB, BFA); Guaramirim, 17/07/1951 (fr.), R. Klein 4 (RB). São Paulo: Mogi-Mirim, 06/10/1931 (fl.), F.C. Hoehne s.n. (RB 2316).

Comentários: Cryptocarya moschata tem sua distribuição geográfica registrada desde Pernambuco a Santa Catarina, habitando a Floresta Pluvial Atlântica e Floresta Seca. Na Reserva, foram coletados apenas dois indivíduos, um em área preservada e outro em área perturbada.

Espécie muito próxima de C. aschersoniana, de difícil separação pelos caracteres florais. Apesar dos frutos de C. moschata terem, nas coleções examinadas, tendência a apresentar sulcos mais profundos na superfície externa, como observado por Vattimo-Gil (1966b), o caráter não demonstra ser constante o suficiente para a delimitação dos táxons. O material coletado foi identificado como C. moschata pelas dimensões das folhas, face adaxial fosca e indumento áureo-tomentoso, os quais diferem de C. aschersoniana, que apresenta folhas menores e face adaxial glabra.

Para complementar a descrição, foi utilizado o maderial em fruto de S. Leone 1905 (HB). 
Cryptocarya micrantha Meisn. in DC., 15: 1.1864.

Figuras 3: C1-C9

Árvore de 2,5 $\mathrm{m}$ de alt., ramos angulosos, marrons, glabros; gemas apicais áureas. Folhas com pecíolo sub-cilíndrico, levemente canaliculado, enegrecido, glabro; lâmina cartácea, lanceolada a elíptica, 5,0 - 12,0 x 1,6-3,8 cm, base aguda, decorrente, margem sub-revoluta, ondulada, ápice agudo a cuspidado, glabrescente, face abaxial sem papilosidade; nervura principal impressa na face adaxial, proeminente na face abaxial; padrão de nervação broquidódromo, nervuras secundárias com percurso quase retilíneo, 7 - 12 pares alternos, ângulo dedivergência $30^{\circ}-35^{\circ}$,nervuras inter-secundárias compostas, reticulado denso. Inflorescência axilar a sub-terminal, panícula, $3,5-5,5 \mathrm{~cm}$ compr., pauciflora. Flores com tépalas ovais, 0,12 - 0,18 cm compr., ápice obtuso, áureo-tomentosas na face ventral, menores que o hipanto urceolado. Estames das séries I e II com filetes 0,03 - 0,04 cm compr., mais delgados que as anteras, pilosos, anteras oval-triangulares, 0,07 - 0,08 cm compr., ápice obtuso ou truncado; série III com filetes $0,03-0,04 \mathrm{~cm}$ compr., mais delgados que as anteras, pilosos, com par de glândula globosa subssésil na base, anteras triangulares, 0,07 - 0,09 cm compr., ápice truncado; série IV estaminodial, estaminódios cordado-sagitados, $0,03-0,05 \mathrm{~cm}$ compr., piloso na face dorsal, subssésil. Ovário elipsóide, estilete cilíndrico, estígma obtuso. Fruto subgloboso a piriforme, 2,0 - 2,5 x 0,5 $1,5 \mathrm{~cm}$, costulado, totalmente incluso no hipanto acrescente, tépalas persistentes no ápice ou decíduas.

Nome popular: Canela-batalha.

Floração e frutificação: Coletada com flores em janeiro e junho, com frutos em abril e junho.

Habitat: Ocorre na Floresta Pluvial Atlântica Baixo-montana e Montana e Floresta Seca.

Distribuição geográfica: No Brasil, nos estados de Minas Gerais, Espírito Santo e Rio de Janeiro.

Material examinado: Coleção da REMC: Sítio Fazenda Velha, 16/08/1990 (veg.), J.F.
Baumgratz s.n. (RB 292401).

Material adicional selecionado: Brasil: Minas Gerais: Rio Novo, s.d. (fl.), Schwacke 6680 (RB). Rio de Janeiro: s.d. (fl.), Riedel s.n. (K); Cachoeira de Macacu, Estação Ecológica Estadual do Paraíso, 22/05/1992 (veg.), B.C. Kurtz et al. s.n. (RB 304760); Petrópolis, estrada RioPetrópolis, 13/04/1939 (fr.), F. Cacerelli s.n.(RB 184189); Nova Iguaçú, Serra do Tinguá, 13/05/ 1943 (fr.), Guerra et Octavio s.n. (RB 48095); Magé, Paraíso, Centro de Primatologia do Rio de Janeiro, próximo à represa, 23/11/1985 (fr.), H.C. Lima 2632 (RB).

Comentários: Cryptocarya micrantha tem sua distribuição geográfica restrita à região Sudeste, tendo seu limite mais ao norte no estado de Minas Gerais, e mais ao sul no estado do Rio de Janeiro, habitando a Floresta Pluvial Atlântica Montana e Floresta Seca. Na Reserva, foi registrada apenas uma única coleta em área perturbada.

Espécie próxima de $C$. minima, diferindo desta pelo fruto de dimensão menor, de até 4,0 $\mathrm{cm}$, e por suas flores com os filetes das duas séries exteriores pilosos e a quarta série estaminodial subséssil, enquanto C.minima apresenta frutos maiores, de até $9,0 \mathrm{~cm}$ compr., e pelas flores com filetes das séries externas glabros e da quarta série estaminodial pedicelada.

Para complementar a descrição, foi utilizado o maderial em flor de Schwacke 6680 (RB) e em fruto de Guerra et Octavio s.n. (RB 48095).

\section{Cinnamomum Schaeff.}

Árvores aromáticas, monóicas. Folhas alternas, sem papilas na epiderme abaxial. Inflorescência em panícula, tirsóide ou tirso. Flores monoclinas, tépalas 6, iguais. Androceu com 9 estames férteis, anteras geralmente quadrilocelares ou raro bilocelares na série III por supressão dos locelos superiores: série I e II com 3 estames cada, anteras introrsas; série III com 3 estames, par de glândulas na base dos filetes, anteras extrorsas; série VI estaminodial presente, sagitada, triangular ou filiforme. Fruto bacáceo, elipsóide ou subgloboso, 
em geral pouco desenvolvido, tépalas persistentes ou decíduas.

Cinnamomum contém de 200-350 espécies, distribuídas principalmente no sudeste da Ásia, representadas também no sudeste da Índia, Austrália e ilhas do Pacífico, não sendo registrada ocorrência na África (Rohwer, 1993b). Nos neotrópicos, o gênero é constituído por 47 espécies, ocorrendo desde o México até o sul do Brasil, Paraguai e norte da Argentina, em altitudes entre 1.000-2.000 m (LoreaHernandes, 1998). No Brasil, o gênero é representado por cerca de 15 espécies. Na REMC, foram coletados Cinnamomum glaziovii (Mez) Kosterm. e Cinnamomum riedelianum Kosterm.

$\mathrm{O}$ gênero é reconhecido com base na combinação de caracteres florais e frutíferos, como próximo de Phoebe e Persea, havendo, muitas vezes, superposição dos caracteres atribuídos aos dois gêneros. Esse problema deve- se, principalmente, à confusão sobre a distribuição geográfica dos mesmos.

Kostermans (1957) restringe as espécies de Phoebe à Ásia, inclui os táxons americanos com pedicelo frutífero cilíndrico ou não, perigônio estreito em Persea e os táxons com pedicelo frutífero espessado e cúpula em forma de disco, subordinados à Cinnamomum. Em 1961, o autor transfere todas as espécies americanas de Phoebe, com frutos de pedicelo frutífero espessado e cúpula pateliforme para Cinnamomum.

Lorea-Hernández (1998), na revisão das espécies neotropicais de Cinnamomum, engloba a maior parte das espécies americanas anteriormente incluídas em Phoebe. O autor altera a circunscrição de Cinnamomum, quando retira as espécies com nervuras pinadas, estaminódios filiformes e cúpula com tépalas não persistentes e as transfere, em sua maior parte, para os gêneros Ocotea e Persea.

\section{Chave para a identificação das espécies de Cinnamomum}

1'- Lâmina elíptica a ovada, padrão de nervação acródromo-broquidódromo, com domácias em tufos de pêlos na axila das nervuras principais 1. C. glaziovii

1 ' - Lâmina lanceolada, padrão de nervação camptódromo-broquidódromo, sem domácias em tufos de pêlos na axila das nervuras principais

2. C. riedelianum

Cinnamomum glaziovii (Mez) Kosterm., Reinwardia 6:21.1961.

Figura 4: A1-A8

Árvore de $17 \mathrm{~m}$ de alt., ramos angulosos, marrons, lisos, alvo-pubescentes, lenticelas esparsas; gemas axilares alvo-seríceas. Folhas com pecíolo canaliculado, pubescente; lâmina cartácea a coriácea, elíptica a ovada, 5,7 - 12,5 x 2,5 - 7,2 cm, base obtusa, decorrente, margem ondulada, revoluta, ápice agudo ou acuminado, face adaxial glabra e abaxial alvopubescente; nervuras principais 3 , impressas na face adaxial e proeminentes na face abaxial; padrão de nervação acródromo-broquidódromo, acródromo imperfeito, de origem su- prabasal na base, broquidódromo no terço superior, reticulado denso; domácias em tufos de pêlos na axila de nervuras primárias. Inflorescência axilar, tirso, 5,0 - 14,0 cm compr., alvo-tomentosa. Flores com tépalas lanceoladas, 0,11 - 0,12 cm compr., ápice agudo, pubescentes na face ventral e dorsal. Estames com anteras quadrilocelares, papilosas, os das séries I e II com filetes 0,05 - 0,06 cm compr., pilosos, anteras ovais, 0,08 - 0,09 cm compr., ápice obtuso a truncado; série III com filetes 0,12 - 0,10 cm compr., seríceos, par de glândula cordado-sagitada na base do filete, anteras retangulares, 0,08 - 0,1 cm compr., locelos superiores lateralmente extrorsos e inferiores 
frontalmente extrorsos; série IV estaminodial presente, estaminódios sagitados, $0,1-0,11 \mathrm{~cm}$ compr., ápice agudo, face dorsal serícea. Ovário globoso, $0,12 \mathrm{~cm}$ compr., glabro, estilete cilíndrico, 0,15 cm compr., estígma discóide, piloso. Fruto não observado.

Floração: Coletadas com flores em abril, junho, agosto e novembro.

Habitat: Ocorre na Floresta Pluvial Atlântica Montana.

Distribuição geográfica: Nos estados do Paraná, Rio de Janeiro, Rio Grande do Sul, Santa Catarina e São Paulo (Nicolau, 1999).

Material examinado: Coleção da REMC: Nascente do Rio das Flores 25/10/1989 (fl.), I.A. Araújo 80 (RB); Caminho para casa do João Luiz, antes do portão, 26/10/1989 (fl.), I.A. Araújo 92 et al. (RB); Nascente do Rio das Flores, caminho para a parcela I, 02/11/90 (fl.), H.C. Lima 4018 (RB); Estrada para Macaé de Cima, 18/10/1988 (fl.), H.C. Lima et al. 3436 (RB, CEPEC, GUA, MO, NY, SP, UEC).

Comentários: Cinnamomum glaziovii tem distribuição geográfica restrita às regiões Sudeste e Sul, apresentando o seu limite mais ao norte no estado do Rio de Janeiro e mais ao sul no estado do Rio Grande do Sul, sendo exclusiva da Floresta Pluvial Atlântica Montana. Foram coletados na REMC três indivíduos em área não preservada. Diferenciase das demais espécies da Reserva por suas folhas com padrão de nervação acródromobroquidódromo.

Lorea-Hernández (1998) cita coletas de Glaziou para Macaé de Cima e margem do Rio Piabanha, localidade próxima da Reserva, pertencente ao mesmo componente florestal, porém não examinadas neste trabalho.

Cinnamomum riedelianum Kosterm., Reinwardia 6:23.1961.

Figura 4: B1

Árvore de 6-14 m alt., ramos subangulosos, áureo-tomentosos; gemas apicais, delgadas, áureo-tomentosas. Folhas com pecíolo canaliculado, áureo-tomentoso; lâmina cartácea, lanceolada, 6,2-12,8 x 2,1-4,2 cm, base aguda, margem plana, ápice agudo ou acuminado, glabra em ambas as faces; nervura principal 1, impressa na face adaxial e proeminente na face abaxial; padrão de nervação camptódromo-broquidódromo, nervuras secundárias conspícuas em ambas as faces, delgadas, 5-8 pares subopostos a alternos, ângulo de divergência $45^{\circ}-50^{\circ}$, nervuras inter-secundárias compostas, reticulado denso, domácias ausentes. Inflorescência axilar tirsóide, 4,0-10,5 cm compr., áureo-tomentosa. Flores com tépalas sub-globosas, 0,12-0,15 cm compr., côncavas, ápice obtuso, áureo- tomentosas. Estames com anteras quadrilocelares, papilosas, os das séries I e II com filetes 0,01-0,015 cm compr., pilosos, anteras quadrangulares, 0,05-0,08 mm compr., margem arredondada, ápice agudo; série III com filete 0,025-0,03 cm compr., piloso, com par de glândula globosa na base, anteras retangulares, $0,1-$ $0,11 \mathrm{~cm}$ compr., ápice truncado, extrorsas, frontal e lateralmente; série IV estaminodial presente, estaminódios romboidais, 0,06-0,07 cm compr. Ovário elipsóide, glabro, estilete delgado, estígma discóide. Fruto elipsóide, 1,8-3,0 cm compr., 1,2-1,5 cm diâm., ápice obtuso, sob cúpula cônica, 0,8-1,2 cm compr., pedicelo espessado.

Nome popular: Canela-garuva.

Floração e frutificação: Coletadas com flores em junho, novembro e dezembro e com frutos em março, novembro e dezembro.

Habitat: Ocorre na Floresta Pluvial Atlântica Montana e Baixo-montana.

Distribuição geográfica: No Brasil, nos estados do Paraná (Vattimo-Gil, 1966a), Rio de Janeiro e Santa Catarina.

Material examinado: Coleção da REMC: Nascente do Rio das Flores, 06/06/1988 (fl.), R. Guedes 2135 (RB); Nascente do Rio das Flores, 16/12/1991 (fl, fr.), M. Nadruz et al. 723 (RB, CETEC, HBG, K, MO, NY, SP, SPSF, UFP)

Material adicional selecionado: Brasil: Rio de Janeiro: Rio de Janeiro, Mata do Horto Florestal, 26/12/1927 (fl.), Antenor s.n. (RB136972, CEPEC, F, INPA, K, MBM, MO, 


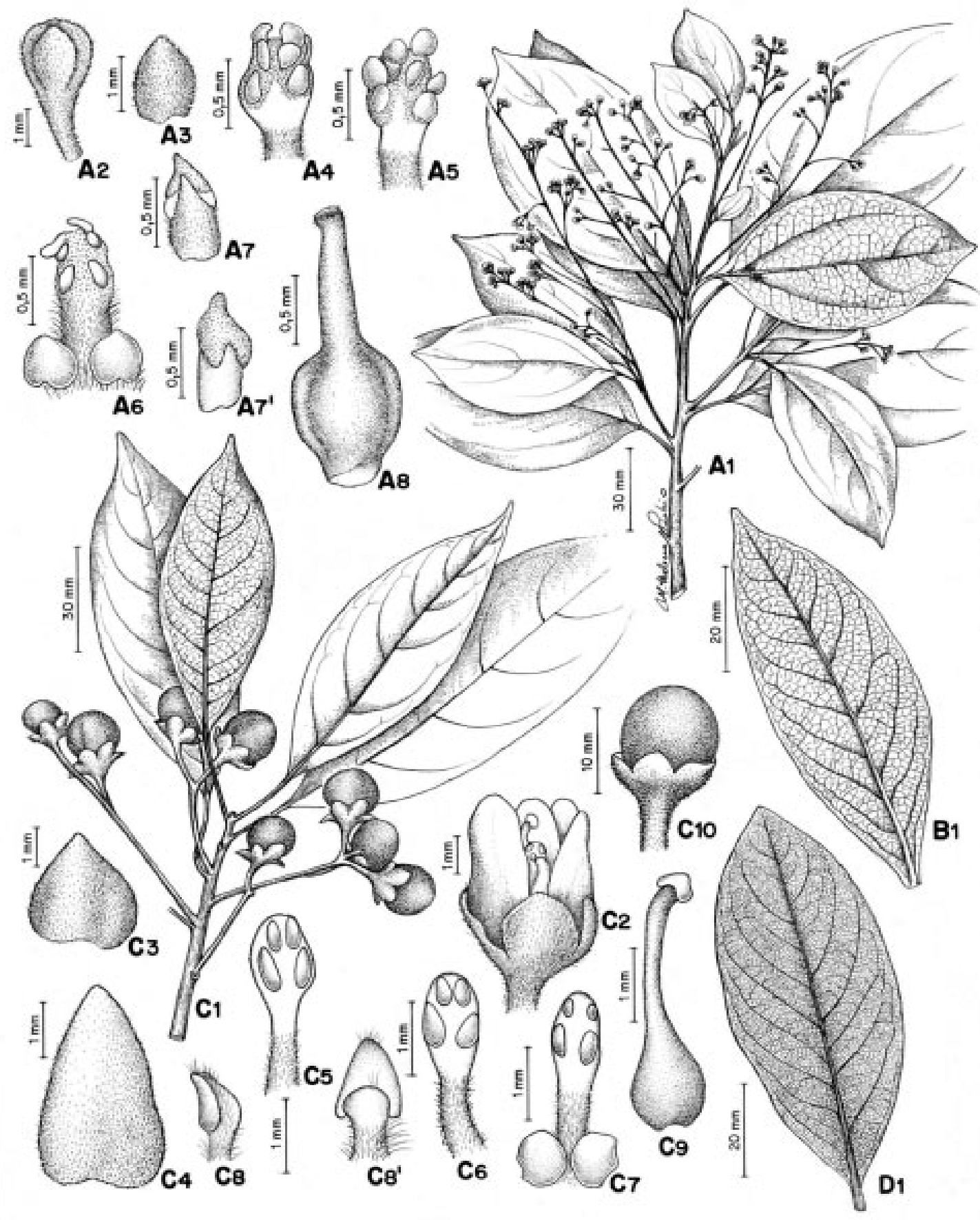

Figura 4 - A. Cinnamomum glaziovii (Mez) Kosterm.: A1 - Ramo florífero; A2 - Botão floral; A3 - Tépala; A4 - Estame da série I; A5 - Estame da série II; A6 - Estame da série III; A7-A7' - Estaminódios da série IV, vistas dorsal e frontal, respectivamente; A8 - Gineceu. B. Cinnamomum riedelianum Kosterm.: B1 - Folha.C. Persea pyrifolia Nees \& Mart. ex Nees: C1 - Ramo frutífero; C2 - Flor; C3 - Tépala externa; C4 - Tépala interna; C5 - Estame da série I; C6 - Estame da série II; C7 - Estame da série III; C8-C8' - Estaminódio da série IV, vistas lateral e frontal, respectivamente. C9 - Gineceu; C10 - Fruto. D. Persea fulva Koop var. fulva : D1 - Folha. (A1-A8, H.C. Lima et al. 3436; B1, M. Nadruz et al. 723; C1-C9, A. Barbosa 99; C10, S.V.A. Pessoa 479; D1, I.A. Araujo 56). 
NY); Ibidem, Mata do Pai Ricardo, estrada da Vista Chinesa, 16/11/1926 (fl.), Pessoal do Horto Florestal s.n. (RB111092). Santa Catarina: Sabiá, Vidal Ramos, 08/03/1958 (fr.), R. Reitz et R.M. Klein 6.600 (RB, FLOR); Itajaí, morro da Fazenda, 01/03/1954 (fl.), $R$. Reitz et R. M. Klein 1707 (RB,FLOR).

Comentários: Cinnamomum riedelianum tem distribuição geográfica restrita à região Sudeste, tendo seu limite norte no estado de Minas Gerais e o sul no estado de Santa Catarina, não penetrando no Rio Grande do Sul, provavelmente devido às condições edáfico-climáticas peculiares deste estado, como já assinalado por vários autores (Lindman, 1906; Klein, 1978; Andreata, 1997). Habita exclusivamente a Floresta Pluvial Atlântica Montana e Baixo-montana. Foi coletada na Reserva apenas em área preservada, sendo localizados oito indivíduos no trecho de um hectare.

Caracteriza-se na Reserva por apresentar filetes curtos, menores que as anteras, e estaminódios da série IV romboidais. Diferencia-se das espécies de Persea da Reserva por estas apresentarem tépalas desiguais e androceu com filetes longos, maiores que as anteras. Das espécies de Ocotea da Reserva, pode ser separada pela forma do estaminódio da série IV, que se caracteriza por ser inconspícuo, ou ausente neste gênero.

Lorea-Hernández (1998) na revisão neotropical de Cinnamomum, inclui $C$. riedelianum no grupo das espécies de posição duvidosa no gênero, por não apresentar folhas acródomas e fruto com cálice persistente e por apresentar hipanto profundo, o que contraria a circunscrição do gênero. Entretanto, algumas das espécies aceitas pelo autor como pertencentes a Cinnamomum apresentam folhas aparentemente acródromas, sendo na realidade camptódromo-broquidódromas e os frutos com tépalas persistentes apenas no início do seu desenvolvimento, sendo posteriormente decíduas, o que contradiz a delimitação proposta. Como o trabalho ainda não foi publicado e por acreditar que os caracteres utilizados para a circunscrição do gênero são inconsis- tentes, manteve-se o binômio proposto por Kostermans (1961).

\section{Persea Mill.}

Árvores monóicas. Folhas alternas, sem papilas na epiderme abaxial. Inflorescência tirso-paniculada. Flores monoclinas, tépalas 6 , iguais ou desiguais, as externas menores que as internas. Androceu com 9 ou 6 estames férteis, anteras quadrilocelares, filetes maiores que as anteras: os das séries I e II com 3 estames cada, anteras introrsas ou com locelos inferiores lateralmente extrorsos; série III com 3 estames, filetes com par de glândula na base, anteras extrorsas ou com locelos inferiores lateralmente extrorsos; série IV estaminodial presente, estaminódios 3, sagitados. Fruto bacáceo, cúpula com tépalas geralmente persistentes.

Persea apresenta cerca de 200 espécies distribuídas na América tropical e temperada e na Ásia. No estado do Rio de Janeiro, segundo Vattimo-Gil (1996), ocorrem 7 espécies. Na Reserva Ecológica de Macaé de Cima, foram coletadas P. fulva var. fulva e P. pyrifolia.

Registrou-se uma das espécies economicamente mais importantes da família, Persea americana var. americana cultivada na área, o abacateiro, porém não tratada neste trabalho. A espécie de origem obscura e, provavelmente, procedente do México, Guatemala e Honduras aclimatou-se nos trópicos do mundo inteiro.

Koop (1966), na última revisão das espécies americanas de Persea, o divide em dois subgêneros: o subgênero Persea - com tépalas iguais, decíduas no fruto, anteras quadrilocelares e glândulas da série III estipitadas; Eriodaphne - com tépalas desiguais, persistentes no fruto, anteras quadrilocelares ou raro somente série III com anteras bilocelares ou, mais raramente, com todas as séries bilocelares, glândulas da série III sésseis. As espécies da Reserva encaixam-se no subgênero Eriodaphne. 


\section{CHAVE PARA A IDENTIFICAÇÃO DAS ESPÉCIES DE PERSEA}

1- Lâmina coriácea, face abaxial ferrugíneo-tomentosa, pecíolo 1,0 - 1,4 cm compr.

1. P. fulva var. fulva

1'- Lâmina cartácea, face abaxial alvo-tomentosa ou glabrescente, pecíolo 1,8 - 3,5 cm compr.

2. P. pyrifolia

Persea fulva Koop. var. fulva, Mem. New York Bot. Gard. 14 (1): 28.1966.

Figura 4: D1

Árvore de $5 \mathrm{~m}$ alt., ramos angulosos, estriados, áureo-tomentosos; gemas apicais áureo-seríceas. Folhas com pecíolo, 1,0 - 1,4 cm compr., canaliculado, delgado; lâmina coriácea, lanceolada ou oblongo-lanceolada, 7,0 - 9,7 x 2,0 - 3,2 cm, base aguda, margem espessa, ápice obtuso ou levemente agudo; face adaxial brilhante, glabra, face abaxial opaca, ferrugíneotomentosa, principalmente sobre as nervuras primária e secundárias; padrão de nervação eucamptódromo, nervuras secundárias $6-8$ pares alternos a subopostos, ângulo de divergência $40^{\circ}-45^{\circ}$, nervuras intersecundárias compostas, reticulado denso. Inflorescência axilar, tirsóide, 4,5 - 14,0 cm compr., áureo-pubérula a áureo-serícea. Flores com tépalas desiguais, áureo-seríceas, as externas menores que as internas, tépalas externas com $0,2-0,25 \mathrm{~cm}$ compr., as internas $0,26-0,31 \mathrm{~cm}$ compr. Estames das séries I e II com filetes 0,05 - 0,06 cm compr., pilosos, anteras ovais, $0,1-0,15 \mathrm{~cm}$ compr., ápice obtuso a truncado, glabras, introrsas; estames da série III com filetes 0,08 0,09 cm compr., pilosos, par de glândula na base, anteras retangulares 0,09 - 0,1 cm compr., ápice emarginado, extrorsas; série IV estaminodial presente, estaminódios sagitados, papilosos, pilosos. Ovário elipsóide, estilete cilíndrico, estigma discóide. Fruto globoso, 1,2 - 1,4 cm compr., 1,1 - 1,3 cm diâm., cúpula hemisférica, 0,5 - 0,6 cm compr., 1,1 - 1,3 cm diâm., tépalas persistentes; pedicelo frutífero cônico.

Floração e frutificação: Coletada com flores em fevereiro, com frutos em agosto.

Habitat: Ocorre na Floresta Pluvial Atlântica Montana.
Distribuição geográfica: No Brasil, nos estados de Minas Gerais e Rio de Janeiro.

Material examinado: Coleção da REMC: Trilha na serra dos Pirineus, 16/08/1989 (fr.), I.A. Araujo 56 (RB); Pico do Frade, 07/02/1985, C. Farney 619 (RB).

Material adicional selecionado: Brasil, Minas Gerais: Ouro Preto, s.d. (fl.), L. Damasio s.n. (RB 48655); Ibidem, s.d. (fl.), L. Damazio 2044 (RB); Serra do Ouro Preto, s.d. (fl.), L. Damazio 2046 (RB); Diamantina, Serra do Espinhaço, 21/01/1969 (fl.), H.S. Irwin et al. s.n. (R, NY); Alto do Itacolomi, s.d. (fl.), L. Damazio 2097 (RB); Pico de Itabira, 15/11/1898 (fl.), C.A. Schwacke 13676 (RB).

Comentários: Persea fulva var. fulva tem distribuição geográfica restrita à região Sudeste, com seu limite mais ao norte no estado de Minas Gerais, e o limite sul no estado do Rio de Janeiro. Na Reserva, foram coletados apenas dois exemplares em área preservada, ocupando o estrato arbustivo com indivíduos jovens.

Persea pyrifolia Nees et Mart. ex Nees, Linnaea 8:50.1833.

Figura 4: C1-C10

Árvore de $10 \mathrm{~m}$ alt., ramos angulosos, estriados, esparso alvo-tomentosos; gemas axilares áureo-seríceas. Folhas com pecíolo, 1,8 $3,5 \mathrm{~cm}$ compr.,canaliculado, delgado;lâminacartácea, elíptica ou ovada, 8,5-14,5 x4,0-6,0 cm, base aguda ou obtusa, margem espessa, ápice agudo ou acuminado; face adaxial brilhante, glabra, face abaxial alvo-tomentosa ou glabrescente; padrão de nervação camptódromo-broquidódromo, nervuras secundárias 5 - 7 pares alternos, ângulo de divergência de $40^{\circ}-50^{\circ}$, ner-

Rodriguésia 53 (82): 59-121. 2002 
vuras inter-secundárias compostas, reticulado denso. Inflorescência axilar, tirsóide, 4,0 - 18,0 cm compr., ferrugíneo-tomentosa. Flores com tépalas desiguais, ferrugíneo-tomentosas, as externas menores que as internas, tépalas externas com 0,075 - 0,1 cm compr., as internas com $0,15-0,2 \mathrm{~cm}$ compr. Estames das séries I e II com filetes $0,1-0,11 \mathrm{~cm}$ compr., pilosos, anteras ovais, $0,06-0,08 \mathrm{~cm}$ compr., ápice obtuso a apiculado, introrsas; estames da série III com filetes 0,07 - 0,08 cm compr., pilosos, tão largos quanto as anteras, par de glândula na base, séssil a curto estipitado, anteras ovais, 0,05 - 0,06 cm compr., extrorsas; série IV estaminodial presente, estaminódios sagitados, 0,11 - 0,12 cm compr., papilosos, pilosos no ápice. Ovário globoso, estilete cilíndrico, estigma peltado. Fruto globoso, 0,8 - 1,4 cm compr., 0,9 $1,4 \mathrm{~cm}$ diâm., cúpula pateliforme, $1,2-1,4 \mathrm{~cm}$ compr., tépalas persistentes; pedicelo clavado. Nomes populares: Canela-rosa, abacateirodo-mato.

Floração e frutificação: Coletada com flores de outubro até novembro, com frutos em outubro e dezembro.

Habitat: Ocorre na Floresta Pluvial Atlântica Baixo-montana e Montana e Floresta Seca.

Distribuição geográfica: No Brasil, nos estados de Minas Gerais, Paraná, Rio de Janeiro, Santa Catarina e São Paulo.

Material examinado: Coleção da REMC: Nascente do rio das Flores, 29/08/1990 (fr.), S.V.A. Pessoa 479 (RB); Ibidem, 18/07/1988, H.C. Lima s.n. (RB 292380).

Material adicional: Brasil: Minas Gerais: Pacáu, Serra da Mantiqueira, 02/1913 (fl.), A. Lutz 386 (RB); São José dos Lopes, Lima Duarte, Fazenda da Serra, 21/11/1994 (fl.), V.C. de Almeida s.n. (R190052). Paraná: Sengés, Fazenda Morungava, Rio do Funil, s.d. (fl.), $G$. Hatschbach et R. B. Lange s.n. (RB). Rio de Janeiro: Terezópolis, Serra dos Órgãos km 6, 20/04/1949 (fl.), A. Barbosa 99 (RB). São Paulo: Bocaina, 09/12/1952 (fl.), Markgraf et Apparicio 10425 (RB); Loreto, s.d. (fl.), O. Vechi 206 (R); Igaratá, 12/12/1951 (fr.), M. Kuhlmann 2749 (RB).
Comentários: Persea pyrifolia distribui-se nas regiões Sudeste e Sul, tendo seu limite norte em Minas Gerais e sul em Santa Catarina, ocupa a Floresta Pluvial na faixa atlântica, e porções mais interioranas do estado de Minas Gerais, onde habita locais mais úmidos em áreas de Floresta Seca. É representada na Reserva por apenas cinco indivíduos na área preservada, sendo ciófila e seletiva xerófita.

\section{Nectandra Rol. ex Rottb.}

Árvores ou arbustos monóicos. Folhas alternas, raro subopostas ou opostas no ápice dos ramos, sem papilas na epiderme abaxial. Inflorescência tirsóide ou panícula. Flores monoclinas, tépalas 6, iguais, internamente papilosas. Androceu com 9 estames férteis, anteras quadrilocelares, papilosas, locelos dispostos em arco: série I e II com 3 estames cada, anteras introrsas; série III com 3 estames, par de glândula na base dos filetes, anteras extrorsas; série IV estaminodial presente, 3 estaminódios filiformes ou ausentes. Ovário glabro, elipsóide ou globoso, estilete curto, estígma conspícuo. Fruto bacáceo, elipsóide ou sub-globoso, parcialmente envolvido por cúpula lenhosa ou sob cúpula discóide, tépalas decíduas.

Nectandra tem cerca de 120 espécies distribuídas na América tropical e subtropical, incluíndo as Antilhas. O centro de diversidade encontra-se nas falhas orientais dos Andes e da região da Amazônia peruana (Rohwer, 1993a). É o segundo maior gênero da família, com 42 espécies no Brasil e no estado do Rio de Janeiro, segundo Vattimo-Gil (1996), ocorrem 10 espécies. Na Reserva Ecológica de Macaé de Cima foram coletadas $N$. puberula, N. leucantha e N. oppositifolia.

$\mathrm{O}$ gênero foi primeiramente descrito por Rottboell (1778) e, desde então, seu posicionamento tem sido controvertido em diferentes sistemas de classificação. O principal atributo usado para separar Nectandra de Ocotea foi a disposição dos locelos em arco, caráter variável por haver espécimes intermediários entre os dois gêneros.

Kostermans (1957), propôs um novo 
sistema para a família, tratando Nectandra e Pleurothyrium como subgêneros de Ocotea.

Allen (1966), baseado principalmente na forma das anteras e disposição dos locelos propõe novamente a separação dos gêneros Ocotea, Nectandra e Pleurothyrium.

Rohwer (1993a), na última revisão de
Nectandra, trata-o independentemente de Ocotea, atribuindo como caracteres importantes para a circunscrição de Nectandra, além da disposição dos locelos em arco das anteras, a presença de papilas nas anteras e na face interna das tépalas. Apesar disso, admite a presença de grupos intermediários entre os gêneros.

\section{CHAVE PARA A IDENTIFICAÇÃO DAS ESPÉCIES DO GÊNERO NECTANDRA}

1 -Folhas subopostas a opostas no ápice dos ramos 3. N. oppositifolia

1 '-Folhas alternas em todo o ramo

2 - Lâmina com nervação terciária perpendicular a nervura principal; estames da série I com anteras pentagonais ou arredondadas; fruto globoso, sobre cúpula discóide e delgada

1. N. puberula

2'- Lâmina com nervação terciária oblíqua em relação à nervura principal; estames da série I com anteras orbiculares; fruto elipsóide, envolvido cerca de 1/3 por cúpula em forma de taça e espessa 2. N. leucantha

Nectandra puberula (Schott) Nees, Syst. Laur.332.1836.

Figura 5: C1-C4

Árvore de 15 a 20 m alt., ramos angulosos, acinzentados, tomentosos; gemas axilares ou apicais ferrugíneo-tomentosas. Folhas alternas em todo o ramo; pecíolo canaliculado, tomentoso; lâmina cartácea, lanceolada ou elíptica, 6,0 - 11,0 x 1,4 - 3,5 cm, base aguda, decorrente, margem espessa, revoluta, ápice agudo ou acuminado; face adaxial glabrescente, abaxial áureo-pubérula principalmente ao longo da nervura principal; nervura principal impressa na face adaxial e proeminente na face abaxial; padrão de nervação eucamptódromo, nervuras secundárias formando ângulo de divergência $40^{\circ}-50^{\circ}$, nervuras terciárias perpendiculares à nervura principal, reticulado laxo; domácias em tufos de pêlos na axila de nervuras secundárias. Inflorescência axilar, tirsóide, 4,5-10,5 cm compr., ferrugíneo-tomentosa. Flores com tépalas obovadas, 2,5 - 3,0mm compr., tomentosas na face ventral e papilosas na face dorsal. Estames da série I com filetes subsséseis, anteras pentagonais ou arredondadas, 0,07 - 0,08 cm compr., ápice agudo; série II com filetes subsséseis, anteras pentagonais $0,08-0,1 \mathrm{~cm}$ compr., ápice agudo; série III com filetes subsséseis, par de glândula irregular em sua base, anteras obtrapeziformes, 0,08 - 0,09 cm compr., ápice truncado ou levemente obtuso; série IV estaminodial presente, estaminódios clavados. Ovário elipsóide, glabro, estilete obcônico, estígma triangular. Fruto globoso, 0,8 - 1,2 compr., 0,7 - 1,1cm diâm., sobre cúpula discóide, delgada; pedicelo frutífero espesso no ápice.

Nomes populares: Canela-amarela, canelapreta, canela-babosa.

Floração e frutificação: Coletada com flores em fevereiro e março, frutos em junho.

Habitat: Ocorre na Floresta Pluvial Atlântica Montana e Baixo-montana e Cerrado.

Distribuição geográfica: No Brasil, nos estados do Espírito Santo (Vattimo-Gil, 1966a), Goiás (Vattimo-Gil, 1966a), Mato Grosso, Minas Gerais, Paraná, Rio de Janeiro, Rio Grande do Sul (Vattimo-Gil, 1966a), Santa Catarina e São Paulo.

Usos: Fornece madeira de cor castanho escuro, bastante acetinada, própria para a construção civil e naval. A casca é estomática, antidesintérica, antidiarréica, útil contra moléstias 
do estômago e intestinos (Corrêa, 1926).

Material examinado: Coleção da REMC: Fazenda Sophronites, 20/04/1989 (fl.), H.C. Lima 3543 (RB); Nascente do Rio das Flores, 08/06/1988(fl.), H.C. Lima 3616 (RB); ibidem, 2/8/1989 (fl.), C.M.B. Correia 41 (RB).

Material adicional: Brasil: Mato Grosso: Capão Grande, rio Taguary, 6/1911 (fl.), $C$. Hoehne 3503(R); s.loc., 1964 (fl.), Guena 32 (RB). Minas Gerais: Palmira, mata da represa, 30/09/1937 (fl.), A.C. Brade 15933 (RB); Paraopeba, fazenda Bernardino Valadares, 05/07/1959 (fl.), E.P. Heringer 7067 (RB, UB). Paraná:Tijucas do Sul, Araçatuba, 15/03/1962 (fl.), G. Hatschbach s.n. (RB 130723); São José dos Pinhais, Guaricana, 23/ 01/1986 (fl.), J.M. Silva et P. Ruas 81 (RB). Rio de Janeiro: Rio de Janeiro, Gávea, praça Santos Dummont, 24/02/1959 (fl.), E. Pereira 4526 et A.P. Duarte (RB); Ibidem, Botafogo, Mundo Novo, 04/04/1961 (fl.), A.P. Duarte 5525 (RB); Petrópolis, 21/03/1941 (fl.), A. Silva s.n. (RB 114706); Terezópolis, 05/1917 (fl.), A. Sampaio 2634 (R). Santa Catarina: Rio Novo, Águas Mornas, Imaruí, 14/12/1972 (fr.), R.M. Klein et A. Bresolin 10553 (RB, FLOR); Joinvile, estrada Dona Francisca, 27/ 03/1958 (fl.), R. Reitz et R.M. Klein 6628 (RB, FLOR); Xanxere, Pinheira 3-4 km sul de Aberlardo Luz, 19/11/1957 (fr.), I.B. Smith et $R$. Klein (RB, FLOR). São Paulo: Reserva Florestal da Bocaina, Posses, 7/05/1968 (veg.), D. Sucre et al. 2967 (RB).

Comentários: Nectandra puberula distribuise nas regiões Centro-oeste, Sudeste e Sul, preferencialmente, em formações de Floresta Pluvial Atlântica numa faixa contínua desde o Espírito Santo até o Rio Grande do Sul, raramente em áreas de cerrado em Mato Grosso e Goiás. $\mathrm{Na}$ Reserva, foram coletados quatro indivíduos em área preservada.

É de fácil identificação pela nervação terciária perpendicular à nervura principal, face abaxial com nervuras áureo-pubérulas, margem revoluta, base decorrente. Os frutos são globosos sobre cúpula discóide.

Para complementar a descrição, foi utili- zado o material em fruto de R.M. Klein et A. Bresolin 6628.

Nectandra leucantha Nees, Linnaea 8:48.1833.

Figura 5: B1-B8

Árvore de $5 \mathrm{~m}$ alt., ramos sub-cilíndricos, amarronzados, glabrescentes. Folhas alternas em todo o ramo; com pecíolo canaliculado; 1 âmina cartácea, lanceolada ou ovada, 11,5 - 16,5 x 5,2-6,7 cm, base cuneada, margem ondulada, ápice agudo ou acuminado; face adaxial glabra, face abaxial glabrescente ou pubérula principalmente ao longo de nervura principal; nervura principal impressa na face adaxial e proeminente na face abaxial; padrão de nervação camptódromo-broquidódromo, nervuras secundárias 5 - 8 pares alternos, ângulo de divergência de $30^{\circ}-45^{\circ}$, nervuras intersecundárias compostas e simples, nervuras terciárias oblíquas em relação à nervura principal, reticulado laxo. Inflorescência axilar ou terminal, tirsóide, com redução de tirsóide a botrióide, 4,0 - 12,0 cm compr., ferrugínea-tomentosa. Flores com tépalas elípticas, 0,05 - 0,07 cm compr., ferrugíneo-tomentosas na face ventral e papilosas na face dorsal. Estames da série I com filetes subsésseis, anteras orbiculares, 0,18-0,2 cm compr., papilosas; série II com filetes subsésseis, anteras pentagonais, $0,15-0,17 \mathrm{~cm}$ compr., papilosas; série III filetes sésseis, par de glândula na base, globosa, séssil, anteras parabólicas, 0,15 - 0,16 cm compr., papilosas; série IV estaminodial presente, estaminódios clavados, $0,01 \mathrm{~cm}$ compr. Ovário globoso ou esférico, glabro; estilete cônico, estígma obtuso. Fruto elipsóide 1,5 - 2,5 cm compr., 1,2 - 1,6 cm diâm., envolvido cerca de $1 / 3$ por cúpula espessa em forma de taça, 1,2 - 1,5 cm larg., 0,7 - 0,9 cm compr.; pedicelo frutífero espessado.

Nomes populares: Canela-branca, canelaseca.

Usos: Fornece madeira para marcenaria e carpintaria, não sendo muito durável. As folhas são utilizadas na medicina popular como antileucorréicas e antiblenorrágicas (Corrêa, 1926). 


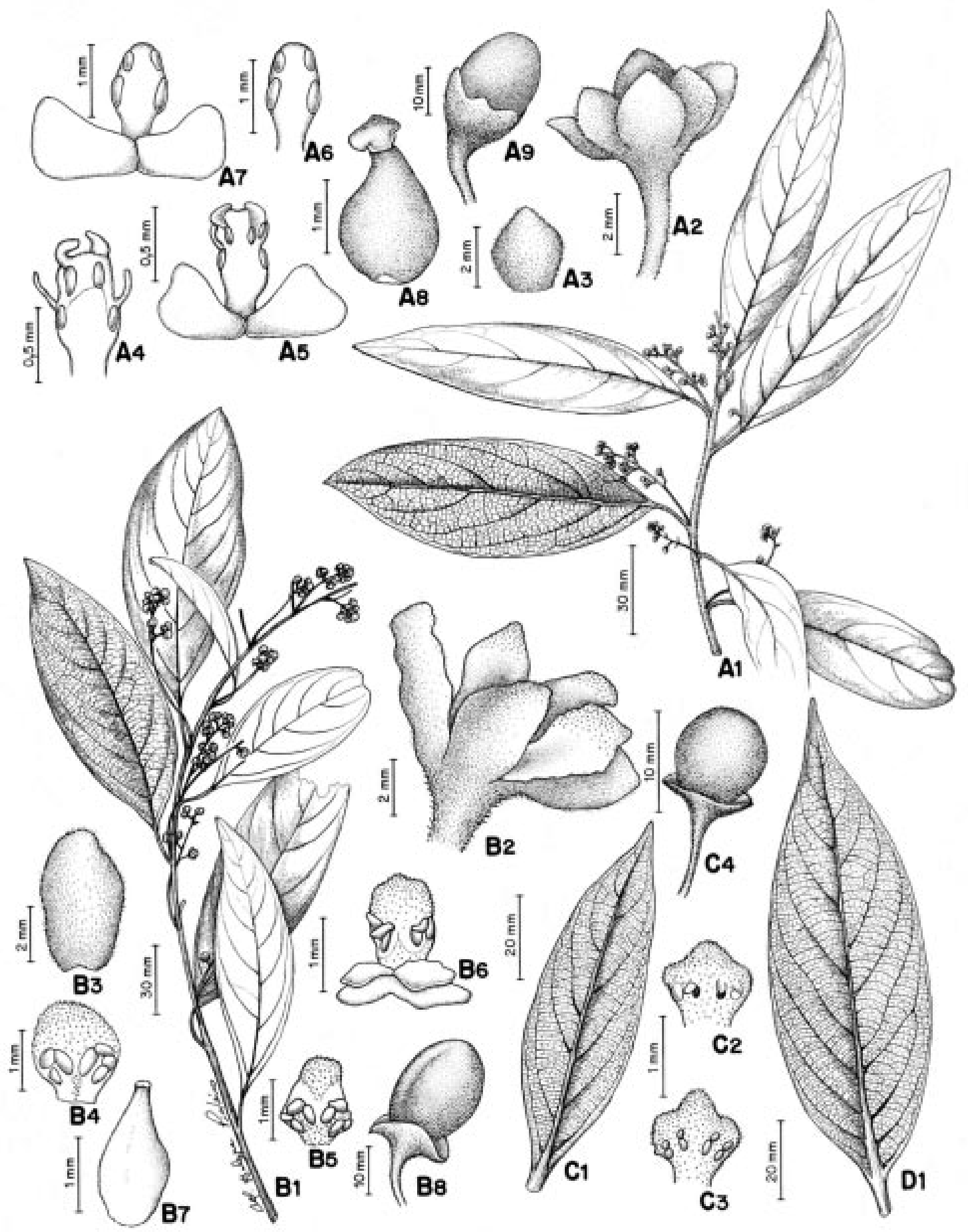

Figura 5 - A. Rhodostemonodaphne macrocalyx (Meisn.) Rohwer ex Madriñán: A1 - Ramo florífero; A2 - Flor; A3 - Tépala; A4 - Estame da série I; A5 - Estame da série III; A6 - Estaminódio da série I; A7 - Estaminódio da série III; A8 - Gineceu; A9 - Fruto. B. Nectandra leucantha Nees: B1 - Ramo florífero; B2 - Flor; B3 - Tépala; B4 - Estame da série I; B5 - Estame da série II; B6 - Estame da série III; B7 - Gineceu; B8 - Fruto. C. Nectandra puberula (Schott) Nees: C1 - Folha; C2 - Estame da série I; C3 - Estame da série II; C4 - Fruto. D. Nectandra oppositifolia Nees: D1 - Folha. (A1-A9, G. Martinelli 12076; B1-B7, E. Pereira 3658; B8, D. Sucre 7781; C1- C3, H.C. Lima 3616; C4, R.M. Klein \& A. Bresolin 6628; D1, S.V.A. Pessoa 517). 
Floração e frutificação: Coletada com flores em janeiro, março, abril, com frutos em julho. Habitat: Ocorre na Floresta Pluvial Atlântica Montana.

Distribuição geográfica: No Brasil, nos estados de Minas Gerais, Paraná, Rio de Janeiro, Santa Catarina e São Paulo.

Material examinado: Coleção da REMC: Nascente do rio das Flores, 09/05/1988 (veg.), G. Martinelli 12811 (RB); ibidem, s.d. (veg.), H.C. Lima s.n. (RB 292226); Sítio Fazenda Velha, 13/08/1990, C.M.B. Correa s.n. (RB 292205).

Material adicional selecionado: Brasil: Minas Gerais: Juiz de Fora, Museu Mariano Procópio, 23/09/1987 (fl.), B.B.S. Coelho 234 (RB). Paraná: Morrotes, 21/04/1904 (fl.), $P$. Dusén 4460 (R); Antonina, Pinheirinho, 26/ 09/1966 (fr.), G. Hatschbach 14752 (RB); Paranaguá, morro da Taquara, 07/06/1979 (fl.), G. Hatschbach 16358 (RB, PKDC). Rio de Janeiro: Rio de Janeiro, Mesa do Imperador, Floresta da Tijuca, 16/04/1958 (fl.),E. Pereira et al. 3658 (RB); Rio das Flores, Fazenda Santa Genoveva, 07/10/1971 (fr.), D. Sucre 7781 (RB); Silva Jardim, Reserva Biológica de Poço das Antas, 04/09/1981 (fr.), E.F. Guimarães 1151 (RB); Nova Iguaçu, Tinguá, 2/ 06/1961 (fl.), M. Emmerich 861 et A.G. Andrade 900 (R). Santa Catarina: Ibirama, 11/ 10/1956 (fl.), R. Reitz et R.M. Klein 3874 (RB; FLOR); Joinvile, estrada Dona Francisca, 26/05/1957 (fl.), R. Reitz et R.M. Klein 4240 (RB, FLOR). São Paulo: Cantareira, 1915 (fl.), H. Paul s.n. (RB6534).

Comentários: Nectandra leucantha com distribuição geográfica nas regiões Sudeste e Sul, tem seu limite norte em Minas Gerais e sul em Santa Catarina, sendo exclusiva da Floresta Pluvial Atlântica Montana.

Foi coletada em Macaé de Cima, em área preservada e em área alterada, e é considerada vulnerável no município do Rio de Janeiro (Quinet, 2000).

Caracterizada pelas folhas lanceoladas ou ovadas, nervação terciária oblíqua em relação à nervura principal e por seus frutos elipsóides, envolvidos em cerca de 1/3 por cúpula em forma de taça e espessa.

Para comnplementar a descrição, foi utilizado o material em fruto de D. Sucre 7781 e em flor de E. Pereira 3658.

Nectandra oppositifolia Nees, Linnaea 8: 47.1833.

Figuras 5: D1

Árvore de 13 a 20 malt., ramos angulosos, ferrugíneo-tomentosos; gemas apicais e axilares ferrugíneo-tomentosas. Folhas subopostas a opostas no ápice dos ramos; pecíolo achatado a canaliculado, ferrugíneo-tomentoso; lâmina cartácea, lanceolada ou elíptica, 5,5 - 12,0 x 1,5 $4,0 \mathrm{~cm}$, base aguda, decorrente, margem revoluta, ápice agudo a acuminado; face adaxial glabrescente à ferrugíneo-tomentosa, face abaxial denso ferrugínea-tomentosa; nervura principal impressa na face adaxial e proeminente na face abaxial; padrão de nervação camptódromobroquidódromo com tendência a formar laços no terço superior, nervuras secundárias 7-8 pares alternos, ângulo de divergência $40^{\circ}-60^{\circ}$, nervuras intersecundárias simples, nervuras terciárias perpendiculares em relação à nervura principal, reticulado denso. Inflorescência axilar, tirsóide, 5,0 - 15,0 cm compr., ferrugíneo-tomentosa. Flores com tépalas elípticas, $0,45 \mathrm{~cm}$ compr., ferrugíneo-tomentosas na face ventral, papilosas na face dorsal. Estames da série I com filetes subsséseis, anteras pentagonais, 0,14 $0,16 \mathrm{~cm}$ compr., ápice obtuso ou agudo, papilosas; série II com filetes subsséseis, anteras pentagonais $0,15-0,17 \mathrm{~cm}$ compr., ápice agudo, papilosas; série III com filetes subsésseis, par de glândula na base, globosa, anteras ovais, 0,16-0,20 cm compr., ápice agudo; série IV estaminodial ausente. Ovário elipsóide, glabro, estilete cônico, estígma discóide. Fruto elipsóide, 1,5 - 1,7 cm compr., 1,0 - 1,1 cm diâm., envolvido por cúpula hemisférica, $0,4-1,0 \mathrm{~cm}$ compr., 0,8 - 1,8 cm diâm., espessa, verruculosa; pedicelo frutífero espesso.

Nomes populares: Canela-garuva, canelabranca.

Floração e frutificação: Coletada com flores 
em fevereiro, maio e junho, com frutos de setembro a janeiro.

Habitat - Ocorre no Brasil na Floresta Pluvial Atlântica Montana e Baixo-montana, Floresta Seca, Floresta Pluvial ripária e em áreas de vegetação secundária.

Distribuição geográfica - No Brasil, nos estados da Bahia (Rohwer, 1993a), Espírito Santo, Minas Gerais, Paraná, Rio de Janeiro, Rio Grande do Sul, São Paulo e Santa Catarina. Colômbia, Bolívia, Equador e Panamá, (Rohwer, 1993a). Usos - Utilizada como madeireira na construção civil e também no paisagismo (Araújo, 1994).

Material examinado: Coleção da REMC: Sítio Fazenda Velha, 12/08/1990 (fr.), C.M.B. Correia 94 (RB); Caminho para os pirineus próximo ao rio das Flores, 01/06/1990 (fl.), S.V.A. Pessoa 517 (RB).

Material adicional selecionado: Brasil: Espírito Santo: entre Linhares e São Matheus, 22/02/1965 (fl.), A.P. Duarte 8852 (RB). Minas Gerais: São José dos Lopes, Lima Duarte, trincheira do alto da campineira, fazenda Secca, 19/03/1994 (fl.), V.C. Almeida s.n. (R10046). Paraná: Paraguá, Fazenda da Agloflora, 22/03/1984 (fl.), P. Ernani s.n (RB 236345). Rio de Janeiro: Rio de Janeiro, Recreio dos Bandeirantes, 16/04/1958 (fl.), E. Pereira 3564 (RB). Rio Grande do Sul: Torres, 02/1939 (fl.), J. Vital s.n (RB 42806). Santa Catarina: Tigipió, São João Batista, 13/04/1961 (fl.), R. Reitz et R.M. Klein 10869 (RB). São Paulo: São Luiz, povoado de Lambary, 07/04/1929 (fl.), J.G. Kuhlmann 205 (RB).

Comentário: Nectandra oppositifolia apresenta ampla distribuição na América Central e América do Sul, apresenta uma distribuição disjunta no Panamá e Colômbia e da Bahia até o Rio Grande do Sul, ocorrendo preferencialmente em áreas de vegetação secundária. Na REMC, há uma alta frequëncia de indivíduos em áreas perturbadas.

Pode ser facilmente reconhecida em campo, pelo tronco reto, de casca lisa, aromático, copa arredondada e pelas folhas subopostas a opostas no ápice dos ramos, lanceoladas a elípticas, em geral densamente ferrugíneo-tomentosas e decorrente. É próxima de $N$. reticulata, da qual difere por apresentar ovário e hipanto glabros (Rohwer, 1993a).

\section{Rhodostemonodaphne Rohwer \& Kubitzki}

Árvores dióicas. Folhas alternas. Inflorescências paniculadas, femininas paucifloras, masculinas multifloras. Flores diclinas, tépalas 6, iguais. Flores masculinas; androceu com 9 estames férteis, anteras quadrilocelares, locelos dispostos em linhas horizontais: séries I e II com 3 estames cada, anteras introrsas; série III com 3 estames, par de glândula volumosa na base dos filetes, anteras extrorsas; série IV estaminodial ausente; pistilóide presente ou ausente. Flores femininas: ovário elipsóide ou globoso, estaminódios de morfologia semelhante a estames dos flores masculinas. Fruto bacáceo, envolvido por cúpula, tépalas persistentes ou decíduas.

Rhodostemonodaphne tem cerca de 20 espécies distribuídas na América do Sul, sendo representado no estado do Rio de Janeiro e na REMC apenas por $R$. macrocalyx (Meisn.) Rohwer ex Madriñán. É próximo de Ocotea e Endlicheria (Rohwer, 1993b).

Rhodostemonodaphne macrocalyx (Meisn.) Rohwer ex Madriñán, Brittonia 48:58.1996.

Ocotea macrocalyx (Meisn.) Mez, Jahrb. Bot. Gart. Berlin 5: 367. 1889.

Figura 5: A1-A9

Árvore $15 \mathrm{~m}$ alt., ramos angulosos, estriados, denso ferrugíneo-tomentosos; gemas axilares e apicais seríceas ou tomentosas. Folhas alternas em todo o ramo; pecíolo áureo-tomentoso ou áureo-pubescente; lâmina coriácea, lanceolada, 6,0 - 10,0 x 3,0 - 4,5 cm, base cuneada, margem sub-revoluta, ápice agudo; face adaxial áureo-tomentosa, principalmente ao longo da nervura principal, face abaxial tomentosa; nervura principal impressa na face adaxial e proeminente na face abaxial; padrão de nervação eucamptódromo, nervuras secundárias 4- 5 pares alternos, ângulo de divergência $40^{\circ}$ - 
$50^{\circ}$, nervuras intersecundárias compostas, reticulado denso; domácias em tufos de pêlos nas axilas das nervuras secundárias. Inflorescência axilar, tirsóide, 3,7 -18,5 cm compr., ferrugíneotomentosa. Flores diclinas, tépalas lanceoladas ou ovais, ápice agudo, ferrugíneo-tomentosas; hipanto áureo-seríceo. Flores masculinas: estames das séries I e II com filetes, 0,025 - 0,035 cm compr., anteras ovais $0,05-0,07 \mathrm{~cm}$ compr., ápice rotundo, papilosas, locelos inferiores lateralmente extrorsos; estames da série III com filetes mais delgados que as anteras, $0,04 \mathrm{~cm}$ compr., par de glândula volumosa na base, anteras ovais, 0,06-0,07 cm compr., papilosas, locelos lateralmente extrorsos, superiores menores que os inferiores; série IV estaminodial ausente; pistilóide ausente. Flores femininas: estaminódios semelhantes às anteras das flores masculinas, reduzidas; ovário elipsóide, estilete cônico, estígma discóide. Fruto elipsóide, 2,93,3 cm compr., 1,4 -1,7 cm diâm., envolvida por cúpula hemisférica, 0,9 - 1,1 cm compr., 1,5 $1,7 \mathrm{~cm}$ diâm., tépalas decíduas; pedicelo frutífero clavado, estriado.

Nome popular: Canela-cedro

Floração e frutificação: Coletada com flores em fevereiro, maio, junho, novembro e, frutos em maio.

Habitat: Ocorre na Floresta Pluvial Atlântica Montana e Baixo-montana.

Distribuição geográfica: No Brasil, nos estados de Minas Gerais, Paraná, Rio de Janeiro e São Paulo.

Usos: Fornece madeira semelhante ao cedro, porém de inferior qualidade, aproveitada para obras internas e carpintaria (Corrêa,1926).

Material examinado: Coleção da REMC: Nascente do rio das Flores, 25/05/1987 (fl., fr.), G. Martinelli 12076 (RB).

Material adicional selecionado: Brasil: Minas Gerais: Rio Novo, s.data (fl.), Araújo s.n. (RB). Paraná: Guaraqueçaba, loalidade de Serrinha, 11/01/1968 (fl.), G. Hatschbach 18272 (RB). Rio de Janeiro: Rio de Janeiro, topo da Pedra da Gávea, 05/10/1967 (veg.), D. Sucre 1623 (RB, HB); Ibidem, Vista Chineza, 01/07/1958 (fr.), E. Pereira et al. 3970
(RB); Ibibem, Serra do Carioca, Tijuca, 17/ 02/1957 (fl.), E.M. Emygdio 1264 (R); Ibidem, Tijuca, estrada do Sumaré, 01/02/1929 (fl.), M. Bandeira s.n. (RB 140136); Teresópolis, Fazenda Boa Fé, picada Davis, 09/04/ 1943 (fl.), H. Vellozo 382 (R).

Comentários: Rhodostemonodaphne macrocalyx apresenta distribuição geográfica restrita às regiões Sudeste e Sul, tendo seu limite norte em Minas Gerais e sul no estado do Paraná, ocorrendo exclusivamente na Floresta Pluvial Atlântica. Foi coletado na Reserva apenas um exemplar em área preservada.

A espécie pode ser confundida vegetativamente com Endlicheria paniculata, por apresentar ápice dos ramos, gemas e folhas com pilosidade serícia a tomentosa e padrão de nervação eucamptódroma. $R$. macrocalyx diferencia-se de E. paniculata pelas folhas coriáceas, face adaxial brilhante, flores com anteras quadrilocelares e frutos parcialmente envolvidos por cúpula, enquanto $E$. paniculata apresenta folhas cartáceas, face adaxial brilhante, flores com anteras bilocelares e frutos sobre cúpula.

Ocotea Aubl.

Árvores monóicas, dióicas ou gimnodióicas. Folhas alternas em todo o ramo ou aparentemente rosuladas no ápice dos ramos floríferos, sem papilas na face abaxial. Inflorescência ou sinflorescência em panícula, tirso, tirsóide ou botrióide. Flores monoclinas ou diclinas, tépalas 6 , iguais ou raro desiguais. Flores masculinas: androceu com 9 estames férteis, anteras quadrilocelares, locelos dispostos em pares superpostos: séries I e II com 3 estames cada, anteras introrsas; série III com 3 estames, par de glândula na base do filete, anteras extrorsas; série IV estaminodial presente reduzida ou ausente; pistilóide presente ou ausente. Flores femininas com estaminódios de morfologia semelhante a estames das flores masculinas; ovário elipsóide ou subgloboso. Fruto bacáceo, sobre ou parcialmente envolvido pela cúpula, em geral com tépalas decíduas.

Ocotea é constituído por cerca de 350 
espécies distribuídas na América tropical e subtropical, desde o México até a Argentina (Rohwer, 1993b). Vattimo-Gil (1996), com base em levantamento no herbário do Instituto de Pesquisas do Jardim Botânico do Rio de Janeiro, aponta para o estado do Rio de Janeiro cerca de 53 espécies. No entanto, de acordo com os sinônimos propostos por Rohwer (1986), esse número foi reduzido a 29 espécies. Na Reserva foram coletadas 18 espécies, sendo elas: Ocotea aciphylla (Nees) Mez, Ocotea catharinensis Mez, Ocotea diospyrifolia (Meisner) Mez, Ocotea dispersa (Nees) Mez, Ocotea divaricata (Nees) Mez, Ocotea domatiata Mez, Ocotea glaziovii Mez, Ocotea indecora (Schott) Mez, Ocotea notata (Nees) Mez, Ocotea odorifera (Vellozo) Rohwer, Ocotea puberula (Rich.) Nees, Ocotea pulchra Vattimo-Gil, Ocotea silvestris Vattimo-Gil, Ocotea spixiana (Nees) Mez, Ocotea tabacifolia (Meisner) Rohwer, Ocotea teleiandra (Meisner) Mez, Ocotea urbaniana Mez, Ocotea vaccinioides Mez. Os gêneros Ocotea, Nectandra e Pleurothyrium são filogeneticamente muito próximos, tendo sido tratados como subgêneros de Ocotea por Kostermans (1957), levando em consideração a posição dos locelos, caráter este utilizado também por Mez (1889) para separá-los. Allen (1966) os considerou como táxons independentes, delimitando-os pelos seguintes atributos: Pleurothyrium - presença de um par de glândulas inseridas na base de todas as anteras férteis; Ocotea e Nectandra - pelas glândulas inseridas na base da terceira série e os dois táxons pela disposição dos locelos nas anteras. Rohwer (1986, 1993a), apesar de reconhecer a presença de caracteres intermediários entre os três gêneros, segue a proposta de Allen (1966), que mantém a separação dos gêneros com base na presença das glândulas na base dos filetes de todos os estames férteis e na disposição dos locelos.

\section{CHAVE PARA A IDENTIFICAÇÃO DAS ESPÉCIES DE OCOTEA}

1- Flores monoclinas

2- Lâmina com domácias nas axilas de nervuras secundárias.

3- Lâmina com domácias marsupiformes na axila dos 2 primeiros pares de nervuras secundárias; inflorescência axilar, tirsóide; estaminódios da série IV ausentes; fruto sobre cúpula pateliforme

1. O. domatiata

3'- Lâmina com domácias em tufos de pêlos na axila do $1^{\circ}$ par de nervuras secundárias; sinflorescência terminal, corimbiforme de botrióides; estaminódios da série IV presentes; fruto parcialmente envolvido $1 / 3$ por cúpula hemisférica

2. O. catharinensis

2'- Lâmina sem domácias nas axilas de nervuras secundárias.

4- Sinflorescência terminal corimbiforme de botrióide ou tirsóide; folhas aparentemente verticiladas no ápice dos ramos floríferos e alternas em ramos vegetativos. 5- Sinflorescência corimbiforme de tirsóide; gemas apicais enegrecidas (em material seco), com até $1 \mathrm{~cm}$ de compr.; fruto envolvido por cúpula hemisférica, verruculosa 3. O. odorifera

5'- Sinflorescência corimbiforme de botrióide; gemas apicais aureo-seríceas (em material seco), com até $0,5 \mathrm{~cm}$ de compr.; fruto envolvido por cúpula obcônica, lisa 4. O. indecora 
4' - Inflorescência axilar, às vezes terminal, tirsóide, panícula, botrióide ou metabotrióide; folhas alternas em todo o ramo.

6 - Lâmina linear, face abaxial ferrugíneo-tomentosa

5.O. urbaniana

6'- Lâmina lanceolada ou elíptica, face abaxial alvo-tomentosa ou áureo-serícia.

7 - Lâmina com face adaxial brilhante, face abaxial subglabra a áureoserícia, ápice longo-acuminado

6. O. aciphylla

7'- Lâmina com face adaxial opaca, face abaxial alvo-tomentosa, ápice agudo

7. O. vaccinioides

1' Flores diclinas

8 - Lâmina com nervuras terciárias oblíquas em relação à nervura principal_8.O. tabacifolia 8' - Lâmina com nervuras terciárias não oblíquas em relação a nervura principal.

9 - Lâmina com pontoado glandular enegrecido na face adaxial.

10 - Lâmina na face abaxial glabrescente a glabra, face adaxial brilhante.

11 - Estames das séries I e II com filetes quase do mesmo comprimento que as anteras; fruto com cúpula de margem dupla _ 9. O. silvestris

11'- Estames das séries I e II com filetes menores que as anteras; fruto com cúpula de margem simples 10. O. diospyrifolia

10'- Lâmina na face abaxial áureo-pubescente, principalmente ao longo das nervuras principal e secundárias, face adaxial opaca 11. O. dispersa

9'- Lâmina sem pontoado glandular enegrecido na face adaxial.

12- Lâmina com domácias na axila de nervuras secundárias

13 - Lâmina com domácias marsupiformes na axila de nervuras secundárias

1. O. domatiata

13'- Lâmina com domácias em tufos de pêlos na axila de nervuras secundárias.

14 - Lâmina com face adaxial brilhante; padrão de nervação camptódromo-broquidódromo, reticulado denso; flores masculinas com pistilóide 12. O. notata

14' - Lâmina com face adaxial opaca; padrão de nervação eucamptódromo, reticulado laxo; flores masculinas sem pistilóide

13. O. divaricata

12'- Lâmina sem domácias na axila de nervuras secundárias

15- Estames das séries I e II com locelos superiores semelhantes aos inferiores.

16 - Lâmina com reticulado laxo 14. O. teleiandra

16'- Lâmina com reticulado denso.

17 - Anteras das séries I e II retangulares ou quadrangulares

15. O. puberula 
17'- Anteras das séries I e II ovais 16. O. pulchra

15' - Estames das séries I e II com locelos superiores menores que os inferiores.

18 - Folha com face abaxial glabra; padrão de nervação broquidódromo; flores com tépalas desiguais, as externas menores que as internas 17. O. glaziovii

18' - Folha com face abaxial ferrugíneo-tomentosa ou ferrugíneapubérula; padrão de nervação camptódromo; flores com tépalas subiguais 18. O. spixiana

Ocotea domatiata Mez, Jahrb. Bot. Gart. Berlin 5: 305.1889

Figura 6: A1-A8

Árvores de 5 a $10 \mathrm{~m}$ alt., monóicas ou gimnodióicas, ramos angulosos, acinzentados, estriados, lenticelados; gemas apicais, 0,7 - 1,4 cm compr., áureo-tomentosas. Folhas alternas em todo o ramo; pecíolo canaliculado, áureotomentoso a glabrescente; lâmina cartácea, lanceolada a elíptico-lanceolada, 6,0 - 16,0x 1,6$5,4 \mathrm{~cm}$, base aguda, margem espessa, ápice agudo a acuminado; face adaxial glabra, sem pontoado enegrecido, face abaxial glabrescente ou áureo ou alvo-pubérula, principalmente ao longo da nervura principal; padrão de nervação camptódromo-broquidódromo, nervuras secundárias delgadas, 5 - 6 pares alternos, ângulo de divergência $35^{\circ}-45^{\circ}$, nervuras inter-secundárias compostas, reticulado denso; domácias marsupiformes na axila dos dois primeiros pares de nervuras secundárias. Inflorescência axilar, tirsóide. Flores monoclinas ou diclinas femininas, tépalas ovais ou lanceoladas, ápice agudo ou obtuso, áureo-tomentosas. Em flores monoclinas: estames das séries I e II com filetes 0,04-0,05 mm compr., delgados, glabros, anteras ovais a sub-retangulares, $0,11-0,12 \mathrm{~cm}$ compr., papilosas, introrsas; estames da série III com filetes delgados, 0,1 - 0,11 mm compr., par de glândula na base, anteras retangulares, papilosas, extrorsas; série IV estaminodial ausente; pistilóide elipsóide, estígma obtuso. Ovário elipsóide, estilete cilíndrico, estígma discóide. Fruto subgloboso a ovóide, 1,7 - 1,9 cm compr. x 1,2 - 1,4 cm diâm., sobre cúpula pateliforme, 0,5 - 0,6 cm diâm., margem ondulada, tépalas decíduas; pedicelo frutífero oblongo ou clavado.

Floração e frutificação: Coletada com frutos em julho.

Habitat: Ocorre na Floresta Pluvial Atlântica Montana.

Distribuição geográfica: No Brasil, no estado do Rio de Janeiro.

Material examinado: Coleção da REMC: Alto Macaé, município de Nova Friburgo, s.d. (fl.), Glaziou 19805 (RB); Nascente do rio das Flores, 08/07/1989 (fr.), B.C. Kurtz 81 (RB, HBG, MO, NY, SP, SPSF); Ibidem, s.d. (fl.), H.C. Lima s.n. (RB 292265, SPSF); Ibidem, s.d. (fr.), S.V.A. Pessoa et al. s.n. (RB 29238).

Comentários: Ocotea domatiata é endêmica do estado do Rio de Janeiro e até o momento está registrada somente para a Reserva Ecológica de Macaé de Cima, sendo exclusiva, portanto, da Floresta Pluvial Atlântica.

Rohwer (1986), considerou Ocotea domatiata um sinônimo de Ocotea minarum. A espécie $O$. domatiata, cujo exemplar-tipo foi coletado por Glaziou em Macaé de Cima, muito se assemelha quanto aos caracteres vegetativos como florais a $O$. minarum, sendo esta encontrada nos estados de Mato Grosso, Goiás, Minas Gerais e São Paulo. Ambas as espécies apresentam flores, ora monoclinas, ora gimnodióicas. Comparando vegetativamente a foto do espécime-tipo, O. domatiata apresenta folhas com menor número de pares de 
nervuras, reticulado da face adaxial mais proeminente, porém, de uma forma geral, são muito semelhantes. No exame das flores de espécimes do cerrado, tanto bissexuais quanto unissexuais femininas, e comparando-as com os espécimes provenientes de Macaé de Cima, não foram observadas diferenças quanto aos caracteres florais, porém, na comparação de material em fruto oriundo de ambas as áreas, foram encontradas diferenças marcantes entre as duas espécies. Os frutos, coletados em Macaé de Cima, têm a forma subglobosa a ovóide, cúpula pateliforme, margem ondulada, sem tépalas persistentes, pedicelo frutífero oblongo ou clavado. Os frutos de O. minarum apresentam-se sempre oblongos, cúpula pequena, plana, tépalas posteriormente decíduas, pedicelo frutífero cilíndrico ou clavado.

Propõe-se a revalidação do binônimo $O$. domatita, com base nas diferenças apresentadas no fruto e por ocorrer somente em Floresta Pluvial Atlântica, e, até o momento, sua ocorrência ser restrita à Reserva Ecológica de Macaé de Cima, enquanto $O$. minarum habita exclusivamente área do cerrado.

Ocotea catharinensis Mez, Jahrb. Bot. Gart. Berlin 5: 253. 1889.

Figura 6: C1-C2

Árvore de $12 \mathrm{~m}$ alt., monóica, ramos amarronzados, lenticelados, glabrescentes; gemas axilares e apicais, lanceoladas, áureo-seríceas. Folhas alternas em todo o ramo; pecíolo canaliculado, glabro; lâmina cartácea, lanceolada, 4,5 - 7,3 x 1,1 -2,0 cm, base aguda, margem espessa, ápice agudo a acuminado; face adaxial brilhante, glabra, sem pontoado enegrecido, face abaxial opaca, glabrescente; padrão de nervaçãocamptódromo-broquidódromo, nervuras secundárias 4 - 6 pares alternos, ângulo de divergência $40^{\circ}-50^{\circ}$, nervuras inter-secundárias compostas, reticulado denso; domácias em tufos de pêlos na axila do primeiro par de nervuras secundárias. Sinflorescência terminal, corimbiforme de botrióides, botrióides 2,5 - 4,5 cm compr. Flores monoclinas, tépalas na face ventral e dorsal aureo-tomentosas. Estames da sé- rie I e II com filetes 0,08 -0,1 cm compr., antera oval, 0,09-0,12 cm compr., ápice obtuso; série III com filetes $0,08-0,1 \mathrm{~cm}$ compr., com par de glândula globosa na base, antera quadrangular, 0,08 -0,11 cm compr., ápice truncado, locelos superiores lateralmente extrorsos e inferiores frontal à lateralmente extrorsos; série IV estaminodial presente, estaminódios filiformes, tomentosos na base. Ovário elipsóide, glabro, estilete delgado, estígma discóide. Fruto elipsóide, 2,0 - 2,3 cm compr. x 1,0 - 1,4 cm diâm., ápice truncado a obtuso, cúpula hemisférica, 1,1 -1,3 cm diâm., envolvendo parcialmente (1/3)o fruto, margem simples, lenhosa, pedicelo frutífero espesso.

Nome popular: Canela-preta

Floração e frutificação: Coletada com flores o ano inteiro, principalmente de dezembro a janeiro. Frutos com dados insuficientes.

Habitat: Ocorre na Floresta Pluvial Atlântica Montana e Baixo-montana.

Distribuição geográfica: No Brasil, nos estados do Paraná, Rio de Janeiro, Rio Grande do Sul, Santa Catarina e São Paulo. Paraguai.

Material examinado: Coleção da REMC: Sítio Fazenda Velha, 31/08/1989(fl.),S.V.A.Pessoa et al. 497 (RB).

Material adicional: Brasil: Paraná: Guaratuba, localidade de Serraria, próximo ao alto da Serra, 28/07/1960 (veg.), A.P. Duarte s.n. (RB 130790);Campina Grande do Sul, localidade de Jaguatirica, 13/11/1960 (fr.), G. Hatschbach s.n. (RB 108731). Rio Grande do Sul: Guaíba, Praia de Guaíba, 1/1964 (fl.), B. Coe-Teixeira et A.R. Teixeira 18 (SP, HB). Santa Catarina: Alto Matador, Rio do Sul, 12/09/1958 (fl.), R. Reitz et R.M.Klein 7109 (RB, FLOR). São Paulo: Campinas, 15/06/1978 (fl.), L.A.F. Mathes s.n. (RB 184197, UEC); Paranapiacaba, 23/05/1946 (veg.), M. Kuhlmann 3165 (RB, SP). Paraguai: Rio Kapivary, 17/12/1971 (fr.), R.M. Klein et J.A. Lopez 9340 (RB). Comentários: Ocotea catharinensis ocorre no Paraguai e no Brasil somente na costa atlântica, principalmente, nos estados de Santa Catarina, Paraná e Rio Grande do Sul. Trata-se 


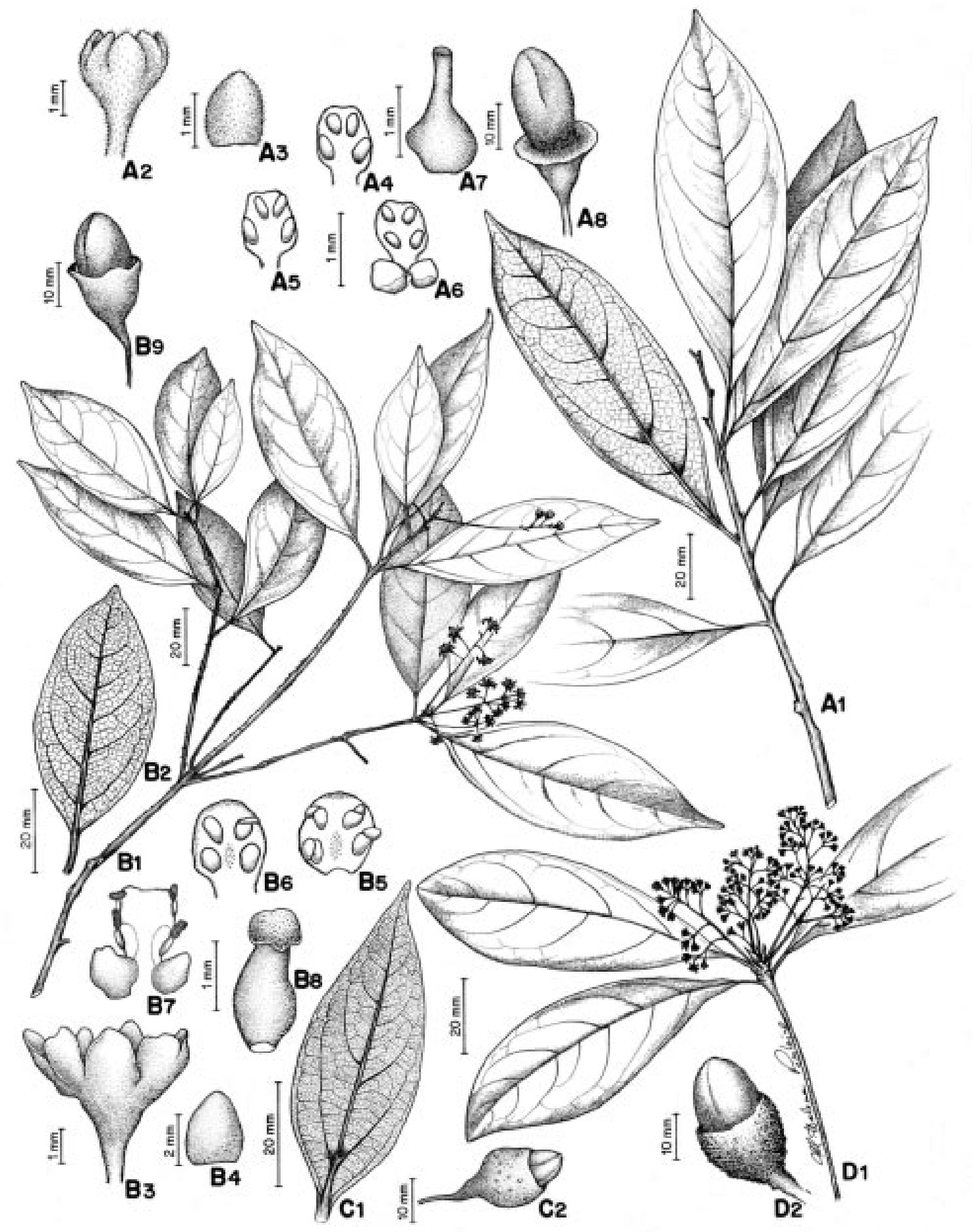

Figura 6 - A. Ocotea domatiata Mez: A1 - Ramo vegetativo; A2 - Flor; A3 - Tépala; A4 - Estame da série I; A5 - Estame da série II; A6 - Estame da série III; A7 - Gineceu; A8 - Fruto. B. Ocotea indecora (Schott) Mez: B1 - Ramo florífero; B2 - Folha; B3 - Flor; B4 - Tépala; B5 - Estame da série I; B6 - Estame da série II; B7 - Estame da série III; B8 - Gineceu; B9 - Fruto. C. Ocotea catharinensis Mez: C1 - Folha; C2 - Fruto. D. Ocotea odorifera (Vell.) Rohwer: D1 - Ramo florífero; D2 - Fruto. (A1, B.C. Kurtz 81, A2-A7, Glaziou 19805; A8, B.C. Kurtz 81; B1- B8, I.A. Araujo 79; B9, S.V.A. Pessoa 267; C1, S.V.A. Pessoa 497; C2, G. Hatschbach s.n. (RB 108731)). 
de uma planta ciófila seletiva higrófila, característica das encostas e topos de morros da Mata Atlântica. Na Reserva, é uma espécie rara, tendo sido coletado apenas um único indivíduo em área mais preservada.

Para complementar à descrição foi utilizado o material em fruto de G. Hatschbach s.n. (RB 108731).

Ocotea odorifera (Vell.) Rohwer, Mitt. Inst. Allg. Bot. Hamburg 20. 278: 111. 1986.

Figura 6: D1-D2

Ocotea pretiosa Mez, Jahrb. Bot. Gart. Berlin 5: 250. 1889.

Árvores de 7 a $18 \mathrm{~m}$ alt., monóicas, ramos angulosos, amarronzados, estriados, glabrescentes; gemas apicais 0,4 - 1,0 cm compr., coriáceas, glabras, enegrecidas em material seco. Folhas aparentemente verticiladas no ápice de ramos floríferos e alternas em ramos vegetativos; pecíolo enegrecido, canaliculado; lâmina cartácea a cartáceo-coriácea, oboval a elíptica, 13,0 - 24,0 x 3,6 - 5,5 cm, base aguda, margem plana, ápice agudo ou acuminado; face adaxial e abaxial glabra, sem pontoado enegrecido; padrão de nervação broquidódromo, nervuras secundárias 6 - 9 pares alternos, ângulo de divergência $45^{\circ}-60^{\circ}$, nervuras intersecundárias compostas, reticulado denso; domácias ausentes. Sinflorescência terminal corimbiforme de tirsóides, tirsóides, 3,5-7,5 cm compr. Flores monoclinas, tépalas lanceoladas ou ovadas, 2,5-3,5 mm compr., glabras; hipanto glabro. Estames das séries I e II com filetes 0,02 $0,04 \mathrm{~cm}$ compr., mais delgados que as anteras, antera sub-orbicular ou ovóide, 0,1-0,13 cm compr., ápice obtuso a agudo, papilosa, introrsa; estames da série III com filetes $0,02-0,04 \mathrm{~cm}$ compr., pilosos, par de glândula na base, antera retangular ou orbicular, 0,075-0,1 cm compr., ápice truncado, papilosa; série IV estaminodial ausente, quando presente, estaminódios liguliformes. Ovário elipsóide, $0,11 \mathrm{~cm}$ compr., glabro, estilete espesso, estígma capitado. Fruto elíptico 1,5 -2,0 cm compr., 1,0 -1,3 cm diâm., envolvido parcialmente (ca.de 1/3) por cúpula hemisférica, 1,0 - 1,4 cm comp., 1,3 - 1,2 cm diâm., verruculosa, crassa; pedicelo frutífero espesso.

Nomes populares: Canela-sassafrás, sassafrás.

Floração e frutificação: Coletada com flores em fevereiro, outubro e dezembro, com frutos em maio e novembro.

Habitat: Ocorre na Floresta Pluvial Atlântica Montana e Baixo-montana.

Distribuição geográfica: No Brasil, nos estados da Bahia, Espírito Santo (Vattimo-Gil, 1966a), Minas Gerais, Paraná, Rio de Janeiro, Rio Grande do Sul, Santa Catarina e São Paulo. Usos: A madeira é utilizada em construção civil e naval; a raiz, o caule, a casca e as folhas encerram óleo essencial usado em perfumaria e com aplicações medicinais (Corrêa, 1926).

Material examinado: Coleção da REMC: Sítio Fazenda Velha, 16/08/1990 (veg.), J.F. Baumgratz s.n. (RB 292397); Ibidem, 13/08/ 1990 (veg.), C.M.B. Correia s.n. (RB 292342). Material adicional selecionado: Brasil: Minas Gerais: Carmo do Rio Claro, Fazenda Novo Horizonte, 26/08/1961 (fl.), A.G. Andrade 947 et M. Emmerich 908 (HB). Paraná: Flona Irati, 25/10/1975 (veg.), H.G. Richter 11 (RB, BFA); Quedas do Iguaçu, fazenda Giacomet, 11/02/1975 (fl.), H.G. Hichter 111 (RB, BFA). Rio de Janeiro: Terezópolis, Serra dos Órgãos, campo das Bromélias, 25/11/1942 (fl., fr.), E. Pereira 189 (RB). Rio Grande do Sul: s.l., s.d. (fl.), J. Dutra s.n. (R30952). Santa Catarina: Pirão Frio, Sombrio, 28/01/1960 (fl.), R. Reitz et R.M.Klein 9442 (RB, FLOR). São Paulo: Reserva Florestal da Bocaina, Posses, 07/05/1968 (veg.), D. Sucre 2980(HB); Parque do Estado, 26/10/1931 (fr.), F.C.Hoehne s.n. (RB, SP).

Comentários: Ocotea odorifera ocorre do sul da Bahia até o Rio Grande do Sul, habitando a Floresta Pluvial Montana e Baixo-montana da faixa costeira. Na Reserva, foi coletada apenas em área alterada.

Espécie muito próxima de $O$. indecora, da qual se diferencia pelo fruto de cúpula verruculosa, folhas lanceoladas, geralmente maiores, com 13,0-24,0 x 3,6-5,5 cm e gemas api- 
cais robustas, enquanto $O$. indecora apresenta fruto de cúpula lisa, folhas menores, com 5,6 $10,9 \mathrm{~cm} \times 2,0-4,6 \mathrm{~cm}$ e gemais apicais mais delgadas, áureo-seríceas.

Para complementar adescrição, foi utilizado o material em flor e fruto de E. Pereira 189.

Ocotea indecora (Schott) Mez, Jahrb. Bot. Gart. Berlin 5: 249. 1889.

Figuras 6: B1-B9

Árbusto ou árvore de $10 \mathrm{~m}$ alt., monóica, ramos angulosos, estriados, lenticelados, áureopubérulos; gemas apicais e axilares, $0,1-0,5 \mathrm{~cm}$ compr, delgadas, áureo-seríceas. Folhas aparentemente verticilaladas no ápice dos ramos floríferos e alternas em ramos vegetativos; pecíolo canaliculado, liso, enegrecido; lâmina cartácea, lanceolada ou oboval-lanceolada, 5,6 $10,9 \mathrm{~cm} \times 2,0-4,6 \mathrm{~cm}$, base aguda, margem plana a sub-revoluta, ápice agudo ou acuminado; face adaxial glabra, sem pontoado enegrecido, face abaxial glabrescente; nervura principal impressa na face adaxial e proeminente na face abaxial; padrão de nervação broquidódromo, nervuras secundárias 4 - 8 pares alternos, ângulo de divergência de $40^{\circ}-45^{\circ}$, nervuras inter-secundárias compostas, reticulado denso; domácias ausentes. Sinflorescência terminal corimbiforme de botrióides, botrióides 3,5 - 5,0 cm compr. Flores monoclinas, tépalas lanceoladas ou ovais, ápice agudo, glabras; hipanto densamente aureo-seríceo. Estames das séries I e II com filetes 0,01 - 0,02 cm compr., anteras suborbiculares ou ovais, 0,12-0,2 cm compr., ápice agudo, papilosas, pilosas na base e no dorso, introrsas; estames da série III com filete, $0,03 \mathrm{~cm}$ compr., piloso, par de glândula subglobosa na base, anteras ovais, $0,15-0,17 \mathrm{~cm}$ compr., ápice truncado, lateralmente extrorsas; série IV estaminodial presente, estaminódios filiformes. Ovário elipsóide, glabro, estilete cilíndrico, estigma discóide. Fruto elíptico de 1,8 -1,9 cm compr., 1,1 - 1,3 cm larg., envolvido parcialmente (ca. de 1/3) por cúpula obcônica, 0,9 - 1,2 compr., 1,4 - 1,5 cm larg., lisa, crassa; pedicelo frutífero espesso.

Nome popular: Canela-preta
Floração e frutificação: Coletada com flores em julho, setembro, outubro e novembro, com frutos em agosto.

Habitat: Ocorre na Floresta Pluvial Atlântica Montana e Baixo-montana.

Distribuição geográfica: Minas Gerais, Rio de Janeiro, Paraná (Vattimo-Gil, 1956a).

Usos: Fornece madeira pardo-clara para construção civil e marcenaria. As cascas da raiz e do caule são aromáticas, sudoríficas, anti-reumáticas e anti-sifilíticas (Corrêa, 1926).

Material examinado: Coleção da REMC: Sítio Sophronites, 19/08/1987 (fr.), S.V.A. Pessoa 267 (RB, BHCB); Estrada para o sítio Sophronites, 30/11/1990 (fl.), H.C. Lima 4008 (RB, F, MO, SPSF); Nascente do Rio das Flores, 26/10/1989 (fl.), I.A. Araújo 99 (RB); Nascente do Rio das Flores, 25/10/1989 (fl.), I.A. Araújo 79 (RB, CEPEC, RBR); Estrada para sítio do João Luís, 26/10/1989 (fl.), I.A. Araújo 90 (RB); Estrada para Macaé de Cima km 6, 18/10/1988 (fl.), H.C. Lima 3443 (RB); Sítio Fazenda Velha, 13/09/1989 (fl.), H.C. Lima 3704 (RB, GUA, HGB, MO, SP, SPSF).

Material adicional: Brasil: Rio de Janeiro: s.d. (fl.), Glaziou 14286 (P); Rio de Janeiro, Mata do Jardim Botânico, 08/06/1925 (fl.), J.G. Kuhlmann s.n. (RB 17996); Ibidem, Mata do Jardim Botânico, 20/07/1927 (fl.fem.),Antenor s.n. (RB 146880); Casimiro de Abreu, Reserva Biológica de Poço das Antas, 04/09/1981 (fl.), L. Mautone et E.F. Guimarães s.n. (RB 335.338); Teresópolis, Fazenda da Boa Fé, 9/ 01/1943 (fl.), H.P. Vellozo s.n. (R38474).

Comentários: Ocotea indecora tem distribuição geográfica restrita às regiões Sudeste e Sul, com limite norte em Minas Gerais e o sul no estado do Paraná, sendo exclusiva da Floresta Pluvial Atlântica. Foi coletada na Reserva em áreas alteradas e em áreas preservadas como arbusto de $3 \mathrm{~m}$ de altura, com indivíduos atingindo o estrato arbóreo com 10 metros de altura.

Espécie muito próxima de O. elegans, diferenciando-se desta pelas folhas glabras, sem domácias, estames curtos $(0,1-0,2 \mathrm{~mm}$ compr.), pouco diferenciados e anteras orbicu- 
lares ou ovais, enquanto $O$. elegans apresenta folhas pubescentes, principalmente em folhas jovens, e domácias na axila de nervuras secundárias, estames maiores de 0,4-0,6 mm compr., visivelmente diferenciados e anteras ovais.

Ocotea urbaniana Mez, Jahrb. Bot. Gart. Berlin 5:262. 1889

Figura 7: C1-C3

Árvore de $6 \mathrm{~m}$ alt., monóica, ramos subcilíndricos, esparso áureo-tomentosos, lenticelados; gemas apicais 1,5-2,0 cm compr., áureas a ferrugíneo-tomentosas. Folhas alternas em todo o ramo; pecíolo canaliculado; lâmina coriácea, linear, 4,5 -9,0 x 1,2 - 1,6 cm, base aguda, decorrente, margem revoluta, ápice agudo a obtuso; face adaxial brilhante, glabra, sem pontoado enegrecido, face abaxial ferrugíneo-tomentosa; nervura principal impressa na face adaxial e proeminente na face abaxial; padrão de nervação broquidódromo, nervuras secundárias 7 - 9 pares alternos, ângulo de divergência $40^{\circ}-50^{\circ}$, nervuras intersecundárias compostas, reticulado denso; domácias ausentes. Inflorescência terminal subpiramidal, denso ferrugíneo-tomentosa. Flores monoclinas; tépalas ovais, ferrugíneo-tomentosas. Estames das séries I e II com filetes sub-glabros, anteras retangulares; série III com par de glândula na base do filete, anteras retangulares. Ovário subgloboso, estígma obtuso. Fruto elipsóide ou oblongo, 1,5-2,0 cm x 0,8 - 1,0 cm, parcialmente envolvido por cúpula cônica a subhemisférica, 0,6-0,8 cm x 0,8-1,0 cm, tépalas decíduas; pedicelo frutífero espesso, clavado. Floração e frutificação: Coletado com frutos somente no mês de agosto.

Habitat: Ocorre na Floresta Pluvial Atlântica Montana.

Distribuição geográfica: No Brasil, nos estados de Minas Gerais (Mez, 1889) e Rio de Janeiro.

Material examinado: Coleção da REMC: Caminho para os Pirineus, 16/08/1989 (fr.), I.A. Araújo 59 (RB); Serra dos Pirineus, 16/08/ 1989 (fr.), I.A. Araújo 46 (RB).

Comentários: Ocotea urbaniana, com distribuição restrita à região Sudeste, nos estados de Minas Gerais e Rio de Janeiro, é exclusiva da Floresta Pluvial Atlântica Montana. $\mathrm{Na}$ Reserva, foram coletados apenas dois indivíduos em área preservada.

As características do material coletado concordam com a descrição de Mez (1889) para a espécie, apesar do exemplar estar somente com fruto, o que não havia sido descrito pelo autor. Apesar da pouca representatividade de espécimes coletados nos herbários e pela falta de material-tipo para comparação, identificou-se em $O$. urbaniana, com certa reserva.

Para complementar a descrição, já que o material encontrava-se apenas em fruto, foi transcrita a descrição da inflorescência e flores de Mez (1889).

Ocotea aciphylla (Nees) Mez, Jahrb. Bot. Gart. Berlin 5 (2) : 243 .1889.

Figura 7: B1-B10

Árvore de 7 - 19 malt., monóica, ramos angulosos, lenticelados na base, pilosidade serícea; gemas de ápice agudo, densamente áureoseríceas. Folhas alternas em todo o ramo; pecíolo canaliculado, áureo-seríceo; lâmina cartácea a coriácea, lanceolada ou elíptica, 8,0 - 15,0 x 2,3 $-5,0 \mathrm{~cm}$, base aguda ou cuneada, margem espessa, marcadamente revoluta, decorrente, ápice longo-acuminado; face adaxial pardoamarelada, brilhante, glabérrima, sem pontoado enegrecido, face abaxial, opaca, sub-glabra a áureo-serícea; nervura principal impressa na face adaxial e proeminente na face abaxial; padrão de nervação broquidódromo, nervuras secundárias 7-10pares alternos, com ângulo de divergência $45^{\circ}-55^{\circ}$, reticulado denso; domácias ausentes. Inflorescência axilar em panícula, 3,5 - 8,5 cm compr., áureo-serícea. Flores monoclinas, tépalas ovadas ou lanceoladas $0,16-0,20$ cm compr., ápice obtuso, externas áureo-seríceas, internas papilosas. Estames das séries I e II com filetes pilosos, 0,05 - 0,07 cm compr., anteras ovais 0,07-0,1 cm compr., ápice agudo, introrsas; estames da série III com filetes 0,07 $-0,08 \mathrm{~cm}$ compr., pilosos, com par de glândula na base, anteras retangulares, 0,07-0,09 cm 


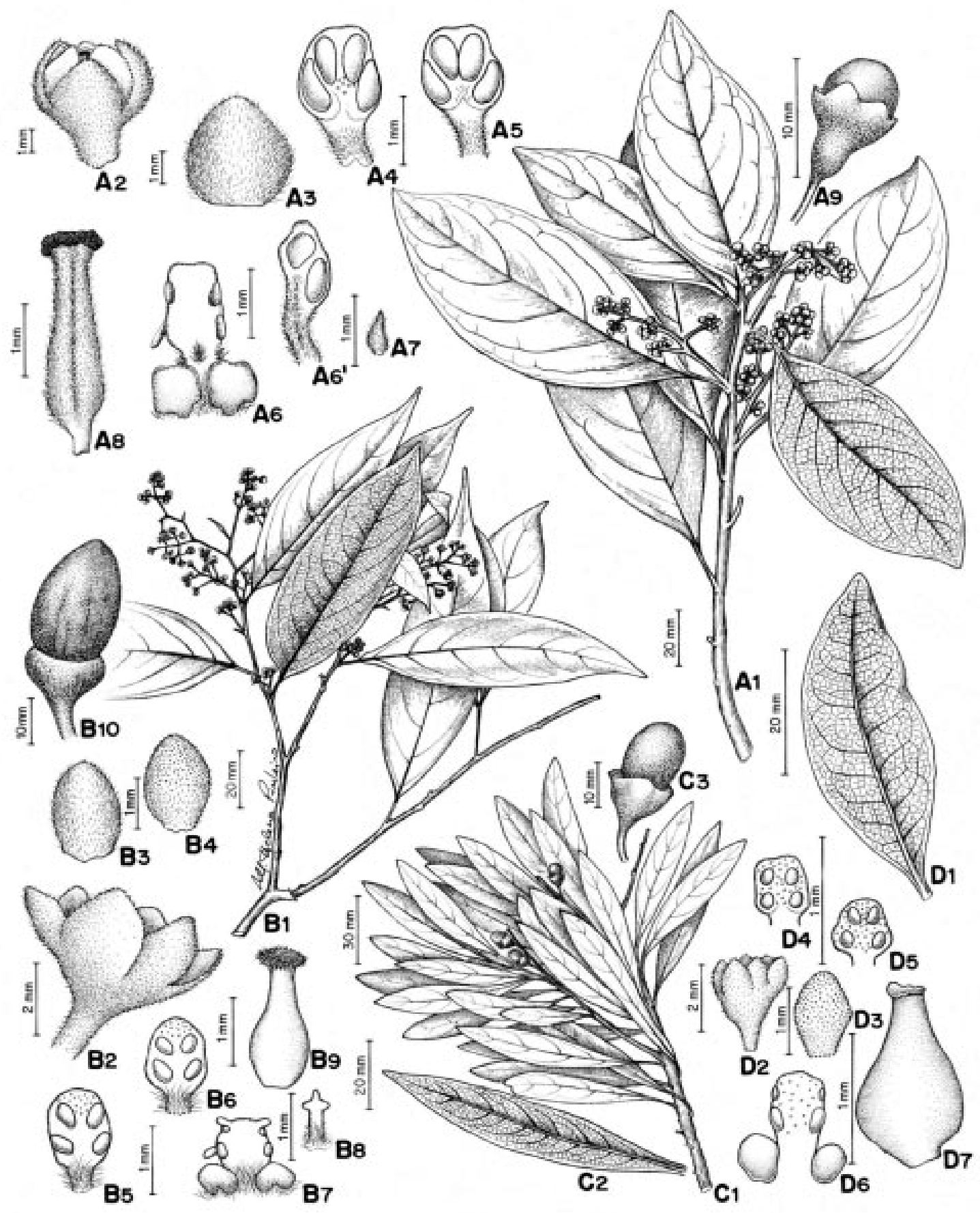

Figura 7 - A. Ocotea spixiana (Nees) Mez: A1 - Ramo florífero; A2 - Flor; A3 - Tépala; A4 - Estame da série I; A5 - Estame da série II; A6-A6' - Estame da série III, vistas frontal e lateral, respectivamente; A7 - Estaminódio da série IV; A8 - Pistilóide; A9 - Fruto. B. Ocotea aciphylla (Nees) Mez: B1 - Ramo florífero; B2 - Flor; B3 - Tépala externa; B4 - Tépala interna; B5 - Estame da série I; B6 - Estame da série II; B7 - Estame da série III; B8 - Estaminódio da série IV; B9 - Gineceu; B10 - Fruto. C. Ocotea urbaniana Mez: C1 - Ramo frutífero; C2 - Folha; C3 - Fruto. D. Ocotea vaccinioides Mez.: D1 - Folha; D2 - Flor; D3 - Tépala; D4 - Estame da série I; D5 - Estame da série II; D6 - Estame da série III; D7 - Gineceu. (A1-A8, B.A.S. Pereira \& D. Alvarenga 3358; A9, P. Furtado 13; B1-B9, R. Guedes 2180; B10, R.P. Belém \& M. Magalhães 1080; C1-C2, I.A. Araujo 59; D1-D7, s. col. (RB 48911)). 
compr., ápice truncado, extrorsas; série IV estaminodial presente, estaminódios filiformes, pilosos. Ovário elipsóide, estilete cônico., estigma sub-discóide, enegrecido, piloso no ápice. Fruto elipsóide, 0,8 - 1,4 cm compr. x 0,8 - 0,9 cm diâm., envolvido por cúpula hemisférica, $0,7-0,9 \mathrm{~cm}$ compr., 1,0 - 1,2 cm diâm., verruculosa, cobrindo cerca de $1 / 4$ do fruto; pedicelo frutífero espessado.

Nomes populares: Canela-amarela, canelaamarela-de-cheiro.

Floração e frutificação: Coletada com flores de outubro a novembro, frutos em dezembro e janeiro.

Habitat: Ocorre nas Florestas Pluviais Amazônica e Atlântica Baixo-montana e Montana, Floresta Seca e Cerrado.

Distribuição geográfica: No Brasil, nos estados do Amazonas, Bahia, Espírito Santo, Goiás, Mato Grosso, Minas Gerais, Paraná, Rio de Janeiro, Santa Catarina, São Paulo. Equador, Guiana, Peru, Suriname e Venezuela.

Usos: Madeira amarela, aromática, resistente a insetos e, sobretudo, a cupins, própria para construção civil e taboado de assoalho. Na medicina, a infusão da casca, que é amarga, é usada contra dores do peito em uso interno e as folhas são sudoríferas (Corrêa, 1926).

Material examinado: Coleção da REMC: Estrada para Sítio Sophronites, 28/12/1989 (fl.), M. Nadruz 535 (RB, MO, SPSF); Nascente do Rio das Flores, Sítio Sophronites, 19/10/1988 (fl.) H.C. Lima 3460 (RB, HRB, MBM, MG, MO); Nascente do Rio das Flores, 07/11/1988 (fl.), R. Guedes 2180 (RB, GUA, BHCB, CEPEC, F, K, MO, NY, RBR, UEC, SPSF); Alto Macaé, s.d. (fl.), Glaziou 19794 (RB, PC); Alto Macahé, s.d. (fl.), Glaziou 18443 (RB, PC).

Material adicional selecionado: Brasil: Amazonas: Galoruca, Rio Preto, 19/04/1952 (fl.), R.L. Fróes 28289 (RB). Bahia: Una, 21/05/1965 (fr.), R.P. Belém et M. Magalhães 1080 (RB, UNB). Espírito Santo: Castelo, Forno Grande, 06/12/1956 (fl.), E. Pereira 2113 (HB, RB); Conceição da Barra, distrito de Dunas de Itauna, fazenda Boa Viagem, 29/10/1983 (fl.), G. Martinelli 9706 (RB, US). Goiás: Brasília, nascente do córrego Palmital, entre Brasília e Luziania, 27/12/1978 (fl.), E.P. Heringer 18399 (RB, IBGE). Mato Grosso: $1 / 2 \mathrm{~km} N$ de Rio Suia-Missu Ferry (aproximadamente $290 \mathrm{~km} \mathrm{~N}$ de Xavantina, 11/05/1968 (fl.), J.A. Ratter et al. 1387 (RB, K). Minas Gerais: Rio Novo, s.d. (veg.), Schwacke 8917 (RB). Paraná: Guaratuba, rio da Praia, 26/07/1960 (fl.), A.P. Duarte et al. 5336 (HB). Santa Catarina: Blumenau, Bom Retiro, mata da companhia Hering, 03/06/1960 (fr.), R. Klein 2453 (RB, FLOR). São Paulo: Cananéia, Ilha do Cardoso, trilha de acesso a captação de água doce, 30/07/1979 (f1.), D.A. de Grande et E.A. Lopes 311 (RB, SP); Cubatão, Vale do Rio Pilões, 04/10/1988 (fl.), H.F. Leitão Filho et S.N. Pagano 20812 (RB, UEC).

Comentários: Ocotea aciphylla distribuise no norte da América do Sul, nas Guianas, Suriname, Venezuela e, mais a oeste, no Peru, Bolívia e Equador, ocupando preferencialmente a Floresta Pluvial Amazônica de Terra Firme. Ocorre também na costa atlântica brasileira desde a Bahia até Santa Catarina, na Floresta Pluvial Atlântica Montana e Baixo-Montana, interiorizando-se, em Minas Gerais, na Floresta Seca e, em Goiás e Mato Grosso, no Cerrado. Foi coletada na REMC, em área alterada, como arbusto e, em área preservada, como componente do estrato arbóreo.

Espécie de fácil identificação, por apresentar folhas longo-acuminadas, face adaxial brilhante, glabérrima e face abaxial opaca, áureo-serícea.

Para complementar a descrição, foi utilizado o material em fruto de R.P. Belém \& M. Magalhães 1080.

Ocotea vaccinioides (Meisn.) Mez, Jahrb. Bot. Gart. Berlin 5: 252. 1889

Figura 7: D1-D7

Árvore de $7 \mathrm{~m}$ alt., monóica, ramos angulosos, tomentosos, lenticelados; gemas apicais áureo-seríceas. Folhas alternas em todo o ramo; pecíolo canaliculado, tomentoso; lâmina cartácea, lanceolada, $2,8-7,0$ × 0,8 - 2,2 cm, base a- 
guda, decorrente, margem espessa, sub-revoluta, ápice agudo a curtamente acuminado; face adaxial glabra, opaca, sem pontoado enegrecido, face abaxial alvo-tomentosa, principalmente ao longo das nervuras principal e secundárias; padrão de nervação broquidódromo, nervuras secundárias 6 - 8 pares alternos, ângulo de divergência $35^{\circ}-40^{\circ}$, nervuras inter-secundárias compostas, reticulado denso; domácias ausentes. Inflorescência axilar, botrióide ou metabotrióide, 1,5 -3,0 cm compr., áureo-serícea. Flores monoclinas, tépalas ovadas $0,1-0,12$ cm compr., ápice obtuso, áureo-seríceas na face ventral e dorsal. Estames das série I e II com filete $0,02-0,03 \mathrm{~cm}$, piloso, anteras ovais a quadrangulares, 0,05 - 0,07 cm compr., ápice obtuso, introrsas, papilosas; série III com filete 0,03 - 0,04 cm compr., piloso, com par de glândula globosa na base, antera oval a quadrangular, 0,03 - 0,05 cm compr., papilosa, extrorsa; série IV estaminodial ausente. Ovário ovóide, estilete espesso, estígma obtuso. Fruto não observado.

Floração: Coletada com flores em março e setembro.

Habitat: Ocorre na Floresta Pluvial Atlântica Montana, Floresta Seca.

Distribuição geográfica: No Brasil, nos estados de Minas Gerais e Rio de Janeiro.

Material examinado: Coleção da REMC: Nascente do rio das Flores, s.d. (veg.), H.C. Lima s.n. (RB 292369).

Material adicional: Brasil: Minas Gerais: Ouro Preto, Serra do Ouro Preto, s.d. (fl.), $L$. Damazio s.n. (RB 48909). Rio de Janeiro: Terezópolis, Serra dos Órgãos, s.d. (fl.), Gardner 5846 (K); Petrópolis, Serra dos Órgãos, s.d. (fl.), s.col. (RB 48911).

Comentários: Ocotea vaccinioides apresenta distribuição restrita à região Sudeste, habitando a Floresta Pluvial Atlântica Montana no estado do Rio de Janeiro e em áreas de pouca disponibilidade hídrica, nas regiões de Floresta Seca no estado de Minas Gerais. Na Reserva, está representada por apenas um indivíduo coletado em área preservada. Tratase de uma espécie rara, pouco representada nos herbários do estado.

Diferencia-se das demais por apresentar folhas lanceoladas, margem espessa, sub-revoluta, base decorrente, ápice agudo a curto acuminado, face abaxial alvo-tomentosa.

Para complementar a descrição, foi utilizado material em flor de s. col. (RB 48911).

Ocotea tabacifolia (Meisn.) Rohwer, Mitt. Inst. Allg. Bot. Hamburg 20. Band. 278: 173. 1986.

Figura 8: A1-A12

Árvore de 14 a 16 malt., dióica, ramos angulosos, estriados, denso ferrugíneo-tomentosos a ferrugíneo-velutinos; gemas apicais, 0,5-1,3 cm compr., ferrugíneo-vilosas. Folhas alternas em todo o ramo; pecíolo anguloso, canaliculado, ferrugíneo-tomentoso; lâmina coriácea, obovada, 24,0 - 36,0 x 12 - 16,0 cm, base cuneada a aguda, margem sub-revoluta, espessa, ápice obtuso a curtamente acuminado; face adaxial áspera, glabrescente a tomentosa áureo-ferrugíneo, sem pontoado glandular enegrecido, face abaxial tomentosa a pubérula; padrão de nervação camptódromo, nervuras secundárias 7-9pares alternos, ângulo de divergência $40^{\circ}-50^{\circ}$, nervuras inter-secundárias compostas, nervuras terciárias oblíquas em relação à nervura principal, reticulado denso; domácias ausentes. Inflorescência axilar, tirsóide, 7,0 - 18,0cm compr., ferrugíneo-tomentosa. Flores diclinas, tépalas oblongas, ápice obtuso a agudo, face ventral ferrugíneo-tomentosa. Flores masculinas: estames das séries I e II com filetes, 0,05 - 0,06 cm compr., antera oval, 0,1 - $0,11 \mathrm{~cm}$ compr., glabra, introrsa; série III com filetes, 0,05 - 0,06 cm compr., mais delgados que as anteras, com par de glândula globosa na base, anteras retangulares, 0,1 - 0,12 cm compr., lateralmente extrorsas; série IV estaminodial ausente, pistilóide presente liguliforme. Flores femininas: anteras de morfologia semelhante à dos estames das flores masculinas, estéreis e reduzidas quase à metade; ovário elipsóide, estígma discóide. Fruto elipsóide, 0,9 - 1,2 cm compr., sobre cúpula $0,8-1,0 \mathrm{~cm}$ compr. e 0,3-0,5 cm diâm., cônica, subcilíndrica, tépalas subpersistentes. 
Floração e frutificação: Coletada com flores em novembro e, frutos em maio e agosto.

Habitat: Ocorre na Floresta Pluvial Atlântica Montana e Baixo-montana, Floresta Seca.

Distribuição geográfica: No Brasil, nos estados de Minas Gerais e Rio de Janeiro.

Material examinado: Coleção da REMC: Sítio Sophronites, 11/09/1990 (fl.fem), C.M.B. Correia 151 (RB); Sítio Fazenda Velha, 14/ 09/1990 (fl.fem.), H.C. Lima 3709 (RB).

Material adicional: Brasil: Minas Gerais: Serra do Cipó, vertente para Conceição do Mato de Dentro, 22/02/1967 (fl.), A.P. Duarte 10408 (RB, HB); Carmésia, 8 km após Carmésia, na estrada Carmésia/morro do Pilar, 21/ 05/1982 (fl.), E.F. Almeida 210 (RB, HRB); Ouro Preto, 04/1892 (fr.), E. Ule 2677 (R); Diamantina, Água Limpa, 25/05/1955 (fl.), E. Pereira 1444 (RB).

Comentários: Ocotea tabacifolia tem distribuição geográfica restrita à região Sudeste, ocorrendo na Floresta Pluvial Atlântica Montana e Baixo-montana no estado do Rio de Janeiro, podendo habitar tambem áreas de pouca disponibilidade hídrica nas regiões de Floresta Seca no estado de Minas Gerais. Na Reserva, foi coletado apenas um indivíduo em área preservada.

Diferencia-se das demais espécies da família na Reserva por apresentar grandes folhas coriáceas (24 - $36 \mathrm{~cm}$ compr.), tomentosas áureo-ferrugíneas na face adaxial e tomentosas a puberulas na face abaxial, nervuras terciárias em ângulo oblíquo em relação à nervura principal.

Para complementar a descrição, foi utilizado o material em flor de E. Pereira 1444 e em fruto de E. Ule 2677.

Ocotea silvestris Vattimo - Gil, Arq. Jard. Bot. Rio de Janeiro 16: 43. 1959.

Figuras 8: B1-B14

Árvore de 13 m alt., dióica, ramos cilíndricos a sub-angulosos emdireção ao ápice, esparso áureo-tomentosos; gemas apicais áureo-seríceas. Folhas alternas em todo o ramo, pecíolo canaliculado, áureo-tomentoso; lâmina cartáceo-co- riácea, lanceolada, 3,0 - 10,4 x 1,2-3,8 cm, base aguda, decorrente, margem espessa, sub-revoluta, ápice agudo a curto acuminado; face adaxial brilhante, glabra, com pontuado glandular enegrecido, face abaxial opaca, glabrescente; padrão de nervação broquidódromo, nervuras secundárias 4-6 pares alternos, ângulo de divergência $35^{\circ}-45^{\circ}$, nervuras inter-secundárias compostas, nervuras terciárias não oblíquas em relação à nervura principal, reticulado denso. Inflorescência axilar, panícula, seríceo-tomentosa, 2,5 $-5,5 \mathrm{~cm}$ compr. Flores diclinas, tépalas ovais com 0,27 - 0,3 cm compr., glabras a denso velutinas. Flores masculinas: estames das séries I I II comfiletes, 0,07-0,1 cm compr., quase do mesmo comprimento que as anteras, anteras ovais, 0,08 - 0,12 cm compr., ápice obtuso, glabras, introrsas; estames da série III com filetes, 0,1 - 0,14 cm compr., glabros, par de glândula globosa na base, anteras ovais $0,1-0,12 \mathrm{~cm}$ compr., ápice truncado, locelos lateralmente extrorsos; série IV estaminodial ausente, quando presente estaminódios filiformes; pistilóide filiforme. Flores femininas: estaminódios de morfologia semelhante a estames das flores masculinas, reduzidos; ovário elipsóide, glabro, estilete cilíndrico, estígma discóide. Fruto globoso a elíptico 1,0 -1,4 cm compr., 0,8 - 1,0 cm diâm., sobre cúpula pateliforme, $0,2-0,4 \mathrm{~cm}$ compr., 0,7-0,8 cm diâm., margem dupla, tépalas subpersistentes.

Nomes populares: Canela-copaiba, canelapreta.

Floração e frutificação: Coletada com flores em fevereiro e agosto, frutos de fevereiro a abril.

Habitat: Ocorre na Floresta Pluvial Atlântica Montana e Baixo-montana.

Distribuição geográfica: No Brasil, nos estados do Paraná, Rio de Janeiro, Santa Catarina e São Paulo.

Material examinado: Coleção da REMC: Sítio Fazenda Velha, 14/08/1990 (fr.), C.M.B. Correia s.n (RB 294082); Sítio Huw New Baccus, 2/04/1989 (fl.), H.C. Lima 3508 (RB).

Material adicional selecionado: Brasil: 


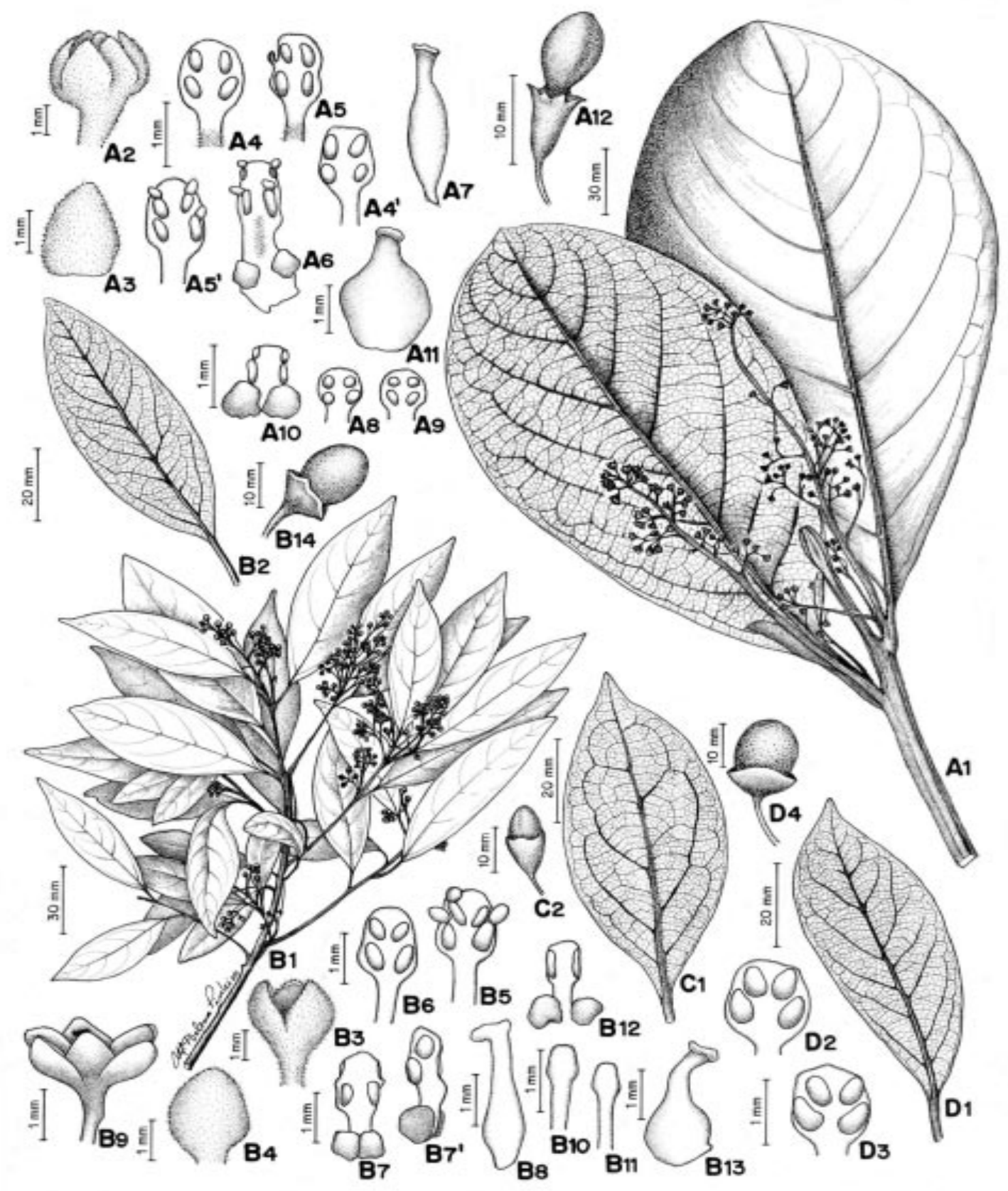

Figura 8 - A. Ocotea tabacifolia (Meisn.) Rohwer: A1 - Ramo florífero; A2 - Flor masculina; A3 - Tépala; A4A4' - Estames da série I; A5-A5' - Estames da série II; A6 - Estame da série III; A7 - Pistilóide; A8 - Estaminódio da série I da flor feminina; A9 - Estaminódio da série II; A10 - Estaminódio da série III; A11 - Gineceu; A12 - Fruto. B. Ocotea silvestris Vattimo-Gil: B1 - Ramo florífero; B2 - Folha; B3 - Flor masculina; B4 - Tépala; B5 - Estame da série I; B6 - Estame da série II; B7-B7' - Estame da série III, vistas frontal e lateral respectivamente; B8 - Pistilóide; B9 - Flor feminina; B10 - Estaminódio da série I; B11 - Estaminódio da série II; B12 - Estaminódio da série III; B13 - Gineceu; B14 - Fruto. C. Ocotea dispersa (Nees) Mez: C1 - Folha; C2 - Fruto. D. Ocotea diospyrifolia (Meisn.) Mez: D1 - Folha; D2 - Estame da série I; D3 - Estame da série II; D4 - Fruto. (A1-A7, E. Pereira 1444 ; A8A11, H.C. Lima 3709; A12, E. Ule 2677; B1-B8, H.C. Lima 3508; B9-B13, E. Pereira 4527 \& A.P. Duarte; B14, C.M.B. Correia s.n; C1, H.C. Lima s.n. (RB 292254); C2, G. Hatschbach s.n. (RB 318798); D1, H.C. Lima 3557, D2D3, O.C. Góes \& D. Constantino 654; D4, N. Kuhlmann 3222). 
Paraná: Monte Alegre, fazenda Klabim, 04/ 08/1960 (fr.), A.P. Duarte 5361 (RB). Rio de Janeiro: Rio de Janeiro, Silvestre, 09/05/ 1930 (fr.), Vitório s.n. (RB 103219); Ibidem, Estrada da Vista Chinesa, 24/02/1959 (fl.), E. Pereira 4527 et A.P. Duarte (RB); Ibidem, Mata do Pai Ricardo, 25/07/1927 (fr.), Pessoal do Horto Florestal s.n. (RB 229899); Ibidem, Corcovado, 04/04/1961 (fr.), A.P. Duarte 5526 (RB). Santa Catarina: Brusque, limoeiro, 22/ 10/1952 (fr.), P.R. Reitz 5.659 (RB, FLOR). São Paulo: São Paulo, Jardim Botânico, 04.04/ 1933 (fl.), O. Handro s.n. (RB, SP30565).

Comentários: Ocotea silvestris distribui-se no Sudeste e Sul do Brasil, tendo seu limite norte no estado do Rio de Janeiro e o limite sul em Santa Catarina, sendo exclusiva da Floresta Pluvial Atlântica Montana e Baixo-montana. Foi coletada na Reserva somente em área preservada.

Diferencia-se das demais espécies de Ocotea ocorrentes na Reserva por apresentar nas folhas, principalmente na face adaxial, pontoado glandular enegrecido, visível ao aumento de 40x e frutos globosos ou elípticos sobre cúpula pateliforme, margem dupla, apresentando cicatrizes vestigias das tépalas parcialmente persistentes.

Para complementar a descrição, foi utilizado o material em flor de E. Pereira 4527 et A. P. Duarte.

Ocotea diospyrifolia (Meisn.) Mez, Jahrb. Bot. Gart. Berlin 5: 374. 1889.

Figura 8: D1-D4

Árvore de 7 a $10 \mathrm{~m}$ alt., dióica, ramos angulosos, estriados, glabrescentes; gemas apicais seríceas, áureo-esverdeadas. Folhas alternas em todo o ramo; pecíolo 1,0 - 1,8 mm compr., delgado, canaliculado; lâmina cartácea, elíptica a estreito - lanceolada, $5,0-8,8 \times 2,0-3,6 \mathrm{~cm}$, base cuneada, levemente decorrente, margem espessa, sub-revoluta, ápice agudo a acuminado; face adaxial verde a verde-amarelada, brilhante, glabra, com pontoado glandular enegrecido, face abaxial glabra; nervura principal impressa na face adaxial e proeminente na face abaxial; pa- drão de nervação broquidódromo, nervuras secundárias 7-9 pares alternos, ângulo de divergência $45^{\circ}-60^{\circ}$,nervuras inter-secundárias compostas, nervurasterciárias não oblíquas em relação à nervura principal, reticulado denso. Inflorescência axilar, tirsóide, 4,5 - 11,5 cm compr., glabrescente. Flores diclinas, tépalas ovais, 0,15 - 0,2 cm compr., ápice obtuso a agudo, glabras; hipanto com pilosidade áureo-velutina. Flores masculinas: estames das séries I e II comfiletes menores que as anteras, 0,01 - 0,03 cm compr., anteras orbiculares a sub-quadrangulares, 0,1 - 0,12 cm compr., ápice truncado, introrsas, papilosas; estames da série III com filetes, 0,05 $0,06 \mathrm{~cm}$ compr., par de glândula na base, anteras retangulares $0,1-0,12 \mathrm{~cm}$ compr., ápice truncado a obtuso, glabras, locelos superiores e inferiores lateralmente extrosos; série IV estaminodial ausente; pistilóide, estipitiforme. Flores femininas: estaminódios de morfologia semelhante aos estames das flores masculinas, reduzidos; ovário ovóide, estilete curto, estigma discóide. Fruto globoso a elipsóide, 1,1 - 1,3cm compr., 0,8 - 0,9 cm diâm., envolvida por cúpula hemisférica, lenhosa, 0,4-0,6 cm compr., 0,9-1,2 cm diâm., margem simples, tépalas decíduas; pedicelo frutífero cilíndrico, espesso.

Nome popular: Canela-preta, canela-amarela.

Floração e frutificação: Coletada com flores em fevereiro, março, outubro e dezembro, com frutos em abril e junho.

Habitat: No Brasil, ocorre na Floresta Pluvial Atlântica Montana e Baixo-montana e na Floresta Seca.

Distribuição geográfica: No Brasil, nos estados de Mato Grosso do Sul, Minas Gerais, Paraná, Rio de Janeiro, Rio Grande do Sul, Santa Catarina, São Paulo. Argentina, Paraguai.

Material examinado: Coleção REMC: Nascente do Rio das Flores, próximo à fazenda Sophronites, 20/04/1989 (veg.), H.C.Lima 3557 (RB, SPSF); 02/06/1989 (veg.), C.M.B. Correia 26 (RB, SPSF); Sítio Fazenda Velha, 7/05/1990 (veg.), R. Guedes s.n. (RB 292267). Material adicional selecionado: Brasil: Mato Grosso do Sul: Fazenda Ilídia, $22^{\circ} 24^{\prime}$ 
Lat. S e 5304' long.W, 22/10/1981 (fl.), P. Furtado s.n. (RB, HRB). Minas Gerais: Ouro Preto, s.d. (fl.), L. Damazio s.n. (RB 48796); Ibidem, s.d. (fl.), L. Damazio s.n. (RB 48795). Paraná: Cerro Azul, estrada antiga Cerro Azul Jaguariaiva, cabeceira do Ribeirão do Tigre, $\mathrm{km} 15 \mathrm{~N}$. de Cerro Azul, 24\%45' lat. $\mathrm{S}$ e $48^{\circ} 43^{\prime}$ long. W, 07/12/1983 (fl.), $R$. Callejas et al. 1882 (RB, K). Rio de Janeiro: Petrópolis, Corrêas, 10/1953 (fl.), O.C. Góes \& D. Constantino 654 (RB). Rio Grande do Sul: Viamão, Itapoâ, Morro do Araçá, 16/10/1979 (fl.), L.W. Aguiar 159(RB, ICN). Santa Catarina: Itapiranga, $27^{\circ} 09^{\prime} \mathrm{S}$ e 534' W, 12/11/1964 (fl.), L.B. Smith et R.M. Klein 13189 (RB, FLOR); Nova Teotônia, 01/12/1944 (fl.fem.), F. Claumann 233 (RB).

São Paulo: São Paulo, Parque do Estado e Jardim Botânico, 07/12/1931 (fl.), F.C. Hoehne s.n. (RB 106190, SP); Jardim Botânico de São Paulo, 08/03/1946 (fr.), $M$. Kuhlmann 3222 (RB, SP); Campinas, 22/09/ 1978 (fl.), L.A.F. Mathes s.n. (RB 184194, UEC).

Comentários: Ocotea diospyrifolia distribui-se na América do Sul e Paraguai, Argentina e no Brasil e é característica da Floresta Pluvial Atlântica Montana e Baixomontana na faixa litorânea sudeste e sul, ocorrendo em Florestas Secas em Minas Gerais e em áreas semideciduais do estado de Mato Grosso doSul. Foi coletada na Reserva apenas em área preservada, sendo representada por um pequeno número de indivíduos.

Para complementar a descrição, foi utilizado o material com flores masculinas de $O$.C. Góes et D. Constantino 654, com flores femininas de $F$. Claumann 233 e fruto de $M$. Kuhlmann 3222.

Ocotea dispersa (Nees) Mez, Jahrb. Bot. Gart. Berlin 5: 357. 1889.

Figura 8: C1-C2

Ocotea riedelii (Meisn.) Mez, Jahrb. Bot.

Gart. Berlin 5: 353. 1889.

Ocotea rubiginosa Mez, Bot. Jahrb. 30, Beibl. 67: 20. 1901
Ocotea hoehnei Vattimo - Gil, Arq. Jard. Bot. Rio de Janeiro 16: 42.1959

Árvore de 13,0 m alt., dióica, ramos subcilíndricos, pardo-tomentosos; gemas axilares, tomentosas. Folhas alternas ao longo de todo o ramo; pecíolo raso-canaliculado, glabrescente a áureo-tomentoso; lâmina cartácea, lanceolada a elíptica, 3,0 -9,0 x 1,4-3,4 cm, base aguda, margem ondulada, ápice acuminado; face adaxial cinza-esverdeada a cinza-castanha, opaca, glabrescente, com pontoado glandular enegrecido, face abaxial castanho avermelhada, opaca, áureo-pubescente, principalmente ao longo das nervuras principal e secundárias; padrão de nervação broquidódromo, nervuras secundárias 4-6 paresalternos, ângulo de divergência $30^{\circ}-45^{\circ}$, nervurasinter-secundárias compostas, nervurasterciárias não oblíquas em relação à nervura principal, reticulado denso; domácias em tufos de pêlos nas axilas das nervuras secundárias ao nível do terço inferior. Inflorescência axilar, botrióide ou metabotrióide, 2,5 5,5 cm compr., pardo-tomentosa ou ferrugíneotomentosa. Flores diclinas, tépalas oblongas ou ovais, ápice agudo, tomentosas ou glabrescentes. Flores masculinas: estames das séries I e II com filetes $0,03-0,05 \mathrm{~mm}$ compr., pilosos, anteras ovóides 0,06 - 0,1 cm compr., introrsas, papilosas; estames da série III com filetes 0,05-0,06 cm compr., pilosos, par de glândula globosa na base, anteras retangulares, 0,07 - 0,1 cm compr., extrorsas; série IV estaminodial ausente; hipanto áureo-viloso, pistilóide ausente ou, quando presente, reduzido, estipitiforme. Flores femininas: estaminódios de morfologia semelhante aos estames das flores masculinas, reduzidos; ovário elipsóide, glabro, estilete espessado, estigma discóide, enegrecido. Fruto ovóide, 0,7 -1,0 cm compr., 0,5-0,7 cm diâm., ápice obtuso, com resquício do estígma, envolvido cerca de $1 / 3$ por cúpula obcônica, $0,5 \mathrm{~cm}$ compr., $0,6 \mathrm{~cm}$ diâm., lenhosa, verruculosa, tépalas persistentes; pedicelo frutífero, espesso.

Nome popular: Canelinha.

Floração e frutificação: Coletada com flores em fevereiro, maio, junho e julho, frutos em 
outubro.

Habitat: Ocorre na Floresta Pluvial Atlân-tica Montana e na Floresta Seca.

Distribuição geográfica: No Brasil, nos estados de Minas Gerais, Paraná, Rio Janeiro, Santa Catarina e São Paulo.

Material examinado: Coleção da REMC: Nascente do Rio das Flores, Sítio Sophronites, 1988 (veg.), H.C. Lima s.n. (RB 292210); Nascente do Rio das Flores, s.d. (veg.),H.C. Lima s.n. (RB 292254); Ibidem, 25-29/07/1988 (veg.), S.V.A. Pessoa s.n. (RB292211).

Material adicional selecionado: Brasil: Minas Gerais: Lambari, 17/09/1961 (fl.), E. Pereira 5785 (HB). Paraná: Paranaguá, rio Cambará, 24/10/1968 (fr.), G. Hatschbach s.n. (RB 318798); Antonina, estrada Cacatu - Serra Negra, 23/03/1966 (fl.fem), G. Hatschbach s.n. (RB 243392). Santa Catarina: Três Barras, Garuva, São Francisco do Sul, 27/02/1958 (fl.), R. Reitz et R.M. Klein 6492 (RB, FLOR). São Paulo: São Paulo, Jardim Botânico, 24/04/1934 (fl.), O. Handro s.n. (RB 114261, SP).

Comentários: Ocotea dispersa apresenta distribuição restrita às regiões Sudeste e Sul, não alcançando o estado de Santa Catarina, ocorrendo na faixa atlântica na Floresta Pluvial Atlântica Montana e em porções mais interioranas do estado de Minas Gerais em locais mais úmidos de Floresta Seca. Foi coletada na Reserva em áreas preservada e alterada, não demonstrando preferência de habitat.

Espécie caracterizada pelas folhas lanceoladas a elípticas, face adaxial cinza-esverdeada a cinza-castanha, com pontoado glandular enegrecido ao longo da lâmina, face abaxial castanho-avermelhada, opaca, áureo-pubescente, principalmente ao longo das nervuras principal e secundárias, padrão de nervação broquidódromo, frutos com cúpula obcônica, lenhosa e tépalas persistentes.

Para complementar a descrição, foi utilizado o material com flores masculinas de O. Handro s.n. (RB 114261), com flores femininas de G. Hatschbach s.n. (RB 243392) e fruto de G. Hatschbach s.n. (RB
318798).

Ocotea notata (Nees) Mez, Jahrb. Bot. Gart. Berlin 5: 339. 1889.

Figuras 9: B1-B12

Ocotea gardneri (Meisn.) Mez, Jahrb. Bot. Gart. Berlin 5: 338. 1889.

Ocotea glaucina (Meisn.) Mez, Jahrb. Bot. Gart. Berlin 5: 340. 1889.

Árvore de $15 \mathrm{~m}$ alt., dióica, ramo anguloso, esparso áureo-tomentoso, lenticelado; gemas áureo-seríceas. Folhas alternas em todo o ramo; pecíolo achatado, 1,2 -1,7 cm compr.; lâmina cartácea, ovada a ovado-lanceolada, 4,1 7,9 x 1,4 - 2,8 cm, base aguda, margem espessa, sub-revoluta, ápice agudo a acuminado; face adaxial brilhante, glabra, sem pontoado glandular enegrecido, face abaxial opaca, esparso áureo-tomentosa, principalmente ao longo das nervuras principal e secundárias; padrão de nervação camptódromo-broquidódromo, nervuras secundárias 5 - 7 paresalternos, ângulo de divergência $45^{\circ}-50^{\circ}$, nervuras inter-secundárias compostas, nervuras terciárias não oblíquas em relação à nervura principal, reticulado denso; domácias em tufos de pêlos nas axilas de nervuras secundárias. Inflorescência axilar ou terminal, botrióide ou metabotrióide, 2,5 -8,4 cm compr. Flores diclinas, tépalas ovadas, ápice agudo, glabrescentes. Flores masculinas: estames das séries I e II com filletes 0,04 - 0,05 cm compr., mais delgados que as anteras, pilosos na base, anteras ovais 0,07 -0,08 cm compr., ápice agudo, glabras, introrsas; estames da série III com filetes 0,05 cm compr., delgados, pilosos, par de glândula globosa na base, anteras retangulares 0,08-0,09 cm compr., ápice obtuso, locelos superiores lateralmente extrorsos e inferiores extrorsos, série IV estaminodial presente, estaminódios liguliformes, pilosos; pistilóide presente, filiforme. Flores femininas: estaminódios de morfologia semelhante a estames de flores masculinas, reduzidos; ovário globoso a elipsóide, estilete espesso, estígma discóide. Fruto globoso a ovóide, 1,2 - 1,3 mm compr., 1,2 - 1,3 cm diâm., sobre cúpula pateliforme ou parcialmente envolvido por cúpula hemisférica, 
0,3 - 0,5 - 0,6 cmcompr., 0,5 - 0,6 - 0,8 cm diâm.; pedicelo frutífero espessado.

Floração e frutificação: Coletada com flores em fevereiro, março e com frutos em maio, junho e novembro.

Habitat: Ocorre na Floresta Pluvial Atlântica Baixo-montana e Montana, Floresta de Tabuleiro e Restinga.

Distribuição geográfica: No Brasil, nos estados da Bahia, Espírito Santo, Minas Gerais, Paraná, Pernambuco, Rio de Janeiro e Sergipe. Material examinado: Coleção da REMC: Nascente do rio das Flores, 26/11/1987 (fr.), G. Martinelli 11905 (RB).

Material adicional selecionado: Brasil: Bahia: Morro do Chapéu, cachoeira do Ferro Doido, 27/10/1978 (fr.), G. Martinelli 5279 (RB); Entre Ajuda e Porto Seguro, 29/08/1961 (fr.), A.P. Duarte 6060 (RB); Salvador, Itapuã, dunas litorâneas da praia do Flamengo, a norte do loteamento Petromar, 31/03/1991 (fl.), H.P. Bautista et A.D.C. Pereira 1558 (RB, HBR). Espírito Santo: Vitória, aeroporto, 19/02/1965 (f1.), A.P. Duarte 8808 (RB); Linhares, Reserva da Companhia Vale do Rio Doce, 24/08/ 1990 (fr.), C. Farney et A.L. Peixoto 2413 (RB). Minas Gerais: Grão Mogol, estrada Grão Mogol, Serra do Jambreiro, rio Extrema, 12/05/1979 (fl.), G. Martinelli 5831 (RB). Paraná: Campo Moirão, 14/10/1965 (fr.), $G$. Hatschbach s.n. (RB 130424). Rio de Janeiro: Rio de Janeiro, Restinga da Marambaia, 17/03/1963 (fl.), G. Pabst 7343 (HB, CHI); Ibidem, Restinga de Grumari, 24/02/1972 (fl. masc.), J. Almeida 1320 (RB, NY, US, MO); Maricá, restinga da Barra de Maricá, 05/03/ 1985 (fl.fem.), V.L.G. Klein 255 et al. (RB). Sergipe: Neópolis, $10^{\circ} 19^{\prime} \mathrm{S}$ e $36^{\circ} 38^{\prime}$ W, 24/ 02/1978 (fl), R.P. Orlandi s.n. (RB, HBR, IPA).

Comentários: Ocotea notata apresenta uma distribuição ao longo da costa atlântica desde Sergipe até o Paraná, ocorrendo principalmente nas Restingas, mas também na Floresta de Tabuleiro e na Floresta Pluvial Atlântica Montana e Baixo-montana e Restinga. Na reserva, foi coletado apenas um exemplar em área pre- servada.

Distingue-se das demais espécies da Reserva por apresentar pecíolos longos e achatados, folhas com a face adaxial brilhante, domácias em tufos de pêlos na axila de nervuras secundárias e frutos globosos sobre cúpula pateliforme ou parcialmente envolvido por cúpula hemisférica. Rohwer (1986), considerou acertadamente $O$. glaucina (Meisn.) Mez e $O$. gardneri (Meisn.) Mez como sinônimos de Ocotea notata. Mez (1889) já as considerava afins entre si, diferenciando-as pela forma das folhas e, principalmente, pelo tipo de habitat; as duas primeiras tidas como típicas de Floresta Atlântica Baixo-montana e Montana e a última restrita à Restinga.

Para complementar a descrição, foi utilizado o material com flores masculinas de J.Almeida 1320 e com flores femininas de V.L.G. Klein 255.

Ocotea divaricata (Nees) Mez, Jahrb. Bot. Gart. Berl. 5: 385.1889.

Figuras 9: A1-A11

Árvore 5-7 m alt., dióica, tronco de casca lisa; ramos angulosos, estriados, glabrescentes. Folhas alternas em todo o ramo; pecíolos enegrecidos, cilíndricos, levemente canaliculados; lâmina cartácea, obovada a elíptica, 6,4-12,0 x 2,7-5,0 cm, base cuneada, margem espessa, ápice acuminado; face adaxial glabra, opaca, sem pontoado glandular enegrecido, face abaxial com pilosidade alvo-pubérula, principalmente ao longo da nervura principal; nervura principal impressa na face adaxial e proeminente na abaxial; padrão de nervação eucamptódromo, nervuras secundárias 3 - 4 pares alternos, ângulo de divergência $35^{\circ}-55^{\circ}$, nervuras intersecundárias compostas, nervuras terciárias não oblíquas em relação à nervura principal, reticulado laxo; domácias em tufos de pêlos na axila das nervuras secundárias. Inflorescência axilar, panícula, 7,5-15,5 cm compr., multiflora. Flores diclinas, alvas, tépalas subiguais, externamente pilosas; hipanto áureoviloso. Flores masculinas: estames com ante- 


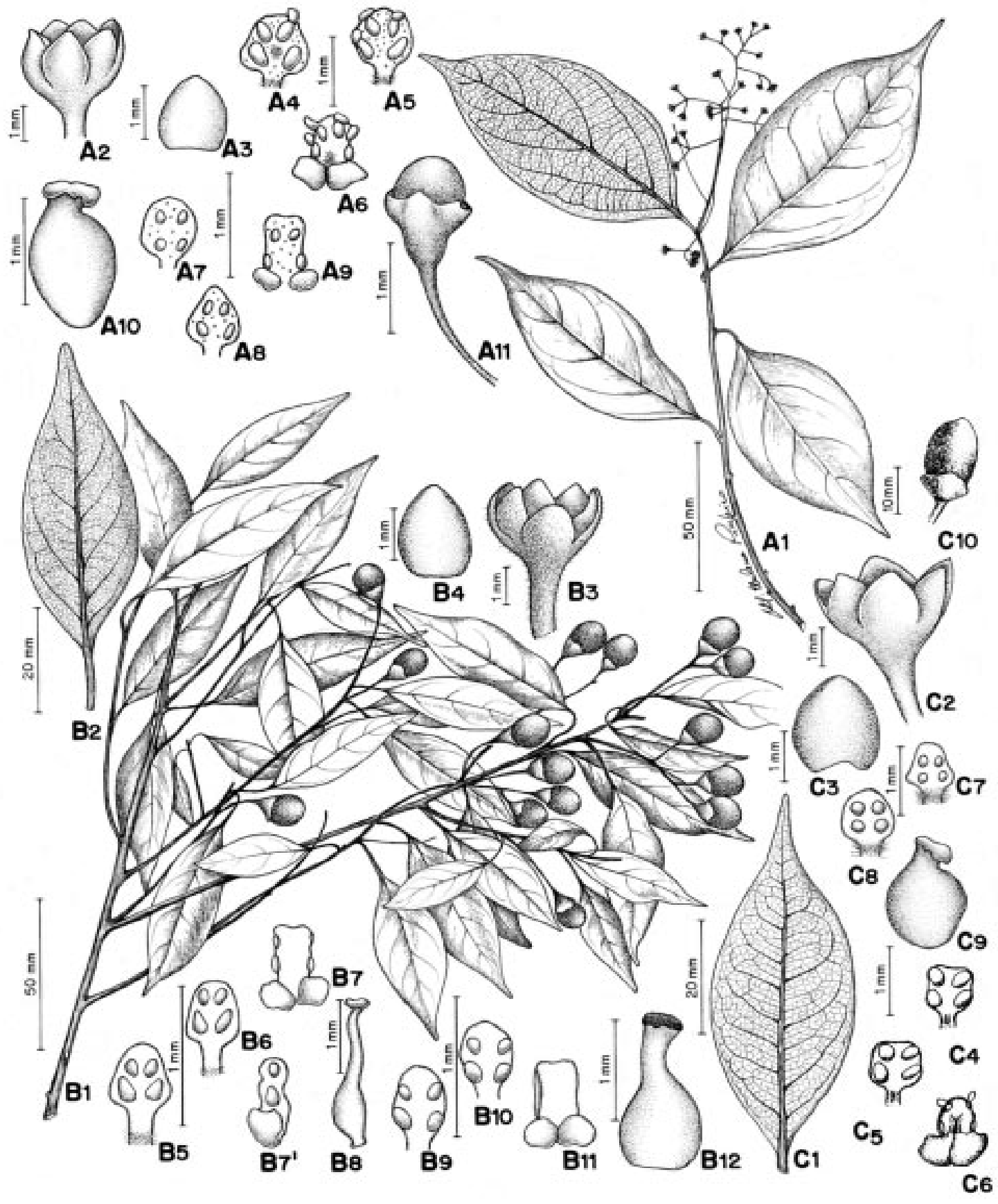

Figura 9 - A. Ocotea divaricata (Nees) Mez: A1 - Ramo florífero; A2 - Flor masculina; A3 - Tépala; A4 - Estame da série I; A5 - Estame da série II; A6 - Estame da série III; A7 - Estaminódio da série I da flor feminina; A8 Estaminódio da série II; A9 - Estaminódio da série III; A10 - Gineceu; A11 - Fruto. B. Ocotea notata (Nees) Mez: B1 - Ramo frutí-fero; B2 - Folha; B3 - Flor masculina; B4 - Tépala; B5 - Estame da série I; B6 - Estame da série II; B7-B7' - Estame da série III, vistas frontal e lateral respectivamente; B8 - Pistilóide; B9 - Estaminódio da série I da flor feminina; B10 - Es-taminódio da série II; B11 - Estaminódio da série III; B12 - Gineceu. C. Ocotea teleiandra (Meisn.) Mez: C1 - Folha; C2 - Flor masculina; C3 - Tépala; C4 - Estame da série I; C5 - Estame da série II; C6 - Estame da série III; C7 - Estaminó-dio da série I; C8 - Estaminódio da série II; C9 - Gineceu; C10 - Fruto. (A1-A6, A. Vaz 678 ; A7A10, T.S. Santos 2434; A11, M. Nadruz 508, B1-B2, G. Martinelli 11905; B3-B8, J. Almeida 1320; B9-B12, V.L.G. Klein 255; C1, C.M.B. Correia s.n. (RB 292409); C2-C6, A. Bresolin 1068, C7-C9, s.c. (RB 48905); C10, O. Vecchi 1190 . 
ras papilosas, os da série I com filetes subsésseis, pouco evidentes, anteras ovais ou suborbiculares, 0,08-0,09 cm compr., ápice rotundo, introrsas; estames da série II com filetes subsésseis, anteras ovais ou suborbiculares, 0,09-0,1 cm compr., mais estreitadas que as da série I, ápice truncado, com apículo curto, introrsas; estames da série III com filetes subsésseis, par de glândula na base, anteras $0,12-0,13 \mathrm{~cm}$ compr., locelos lateralmente extrorsos, ápice obtuso; série IV estaminodial ausente; pistilóide ausente. Flores femininas: estaminódios de morfologia semelhante aos estames das flores masculinas, reduzidos; ovário obovóide, estilete curto, estígma discóide. Fruto globoso, 2,0 - 2,5 cm diâm., 1,8 -2,0 cm compr., envolvido por cúpula de $0,5 \mathrm{~cm}$ compr., tépalas persistentes; pedicelos frutíferos delgados.

Nomes populares: Canela-segueira, canelaamarela, canela-preta

Floração e frutificação: Coletada com flores em maio, setembro, outubro e novembro, frutos em junho e agosto.

Habitat: Ocorre na Floresta Pluvial Atlântica Baixo-montana, Montana e Floresta Seca.

Distribuição geográfica: No Brasil, nos estados da Bahia, Espírito Santo, Minas Gerais, Rio de Janeiro e São Paulo (Coe-Teixeira, 1980).

Material examinado: Coleção da REMC: Estrada para o sítio do João Luis, 26/10/1989 (fl.), A. Araújo 91 (RB, SPSF); Margem do Rio das Flores, 22/06/1989 (fr.), M. Nadruz 508 (RB, SPSF); Próximo à Nascente do Rio das Flores, 21/11/1988 (fl.), S.V.A. Pessoa 405 (RB, MO, SPSF); Sítio Sophronites, 13/09/1989 (fl.), A. Vaz 678 (RB, HRB, NY, GUA); Nascente do Rio das Flores, Sítio Sophronites, 26/ 10/1988 (fl.), H.C. Lima 3430 (RB, F, NY, MO, SPSF); Rio das Flores, 07/11/1988 (fl.), R. Guedes 2177 (RB); Nascente do Rio das Flores, 26/9/1988 (fl.), C.M. Vieira 10 (RB); Ibidem, s.d. (fl.), R. Guedes s.n. (RB 292989); Ibidem, 26/09/1988 (fl.), C.M. Vieira 8 (RB); Ibidem, 25/05/1988 (fl.), S.V.A. Pessoa 332
(RB, BHCB, CEPEC, GUA, HRB, USU, SPSF, K, MO, NY, RBR, UEC).

Material adicional selecionado: Brasil: Bahia: Olivença km 21 para a fazenda Ipiranga ao norte, 22/09/1972 (fl.), T.S. Santos 2434 (RB, CEPEC). Minas Gerais: Viçosa, E.S.A.V., 16/09/1935 (fl.), s.col. (RB 136587); Rio Novo, 08/1889 (fl.), Araújo 20 (R). Rio de Janeiro: Rio de Janeiro, Parque Nacional da Tijuca, Serra dos Pretos Fôrros, represa dos Ciganos, 30/09/1977 (fl.), G. Martinelli 3097 (RB); Ibidem, Alto da Boa Vista, estrada do Açude da Solidão, 06/01/1944 (fl.), M.H. Valle s.n. (R39791).

Comentários: Ocotea divaricata ocorre desde o sul da Bahia até o estado de São Paulo na Floresta Pluvial Atlântica Baixo-montana e Montana e Floresta Seca. Na Reserva, habita principalmente áreas preservadas fazendo parte do componente arbóreo, sendo considerada a espécie de Lauraceae com maior freqüência de indivíduos por hectare.

Espécie próxima de $O$. laxa, diferindo desta por apresentar folhas de dimensões maiores, padrão de nervação eucamptódromo e filetes das séries I e II subsésseis, enquanto $O$. laxa apresenta folhas menores, com padrão de nervação broquidódromo e filetes das séries I e II evidentes.

Para complementar a descrição, foi utilizado o material com flores femininas de T.S. Santos 2434.

Ocotea teleiandra (Meisn.) Mez, Jahrb. Bot. Gart. Berlin 5: 382. 1889.

Figura 9: C1-C10

Arbusto de 2,5 m alt., dióico, ramos subcilíndricos a angulosos, estriados, levemente alvo-tomentosos a glabrescentes; gemas apicais áureo-seríceas. Folhas alternas em todo o ramo; pecíolo canaliculado, delgado, glabrescente; lâmina cartácea, lanceolada a elíptica, 5,2 -7,8 x 2,4-2,8 cm, base cuneada, margem espessa, ondulada, ápice acuminado; face adaxial opaca, glabra, sem pontoado glandular enegrecido, face abaxial esparso pubescente a glabra; nervura principal 
impressa na face adaxial e proeminente na face abaxial; padrão de nervação broquidódromo, nervuras secundárias 4-7 pares alternos, ângulo de divergência $40^{\circ}-50^{\circ}$, nervuras intersecundárias compostas, nervuras terciárias não oblíquas em relação à nervura principal, reticulado laxo; domácias ausentes. Inflorescência axilar, tirsóide, $3,5-6,0 \mathrm{~cm}$ compr., glabrescente. Flores diclinas, tépalas oblongo-lanceoladas ou ovais, ápice agudo, subiguais, as externas semelhantes às internas, papilosas na face ventral e dorsal; hipanto seríceo-ferrugíneo. Flores masculinas: estames das séries I e II com filetes 0,02 $0,03 \mathrm{~cm}$ compr., mais delgados que a antera, pilosos na base, antera retangular-ovalada, 0,09-0,12 cm compr., ápice obtuso, com pontos translúcidos, locelos superiores semelhantes aos inferiores, introrsos; estames da série III, 0,02 cm compr., com filetes de mesma largura que a antera, par de glândula globosa na base, anteras retangulares 0,07-0,09 $\mathrm{cm}$ compr., ápice truncado, papilosas, locelos superiores lateralmente extrorsos e inferiores extrorsos; série IV estaminodial ausente ou presente, estaminódios filiformes; pistilóide ausente. Flores femininas: estaminódios de morfologia semelhante aos estames das flores masculinas, reduzidos; ovário globoso, estilete cilíndrico, estígma discóideo. Fruto globoso quando imaturo, a elipsóide quando maduro, 1,0 - 2,2 cm compr., 0,8 $1,4 \mathrm{~cm}$ diâm., sobre cúpula cônica, subhemisférica, 0,5 - 0,7 cm compr., 9,0 - 1,2 cm diâm., crassa, tépalas decíduas; pedicelo espessado.

Nome popular: Canela-preta, canela-fedida, canela-de-folha-miúda.

Floração e frutificação: Coletada com flores em fevereiro, agosto, setembro e com frutos em novembro e dezembro.

Habitat: Ocorre na Floresta Pluvial Atlântica Montana e Baixo-montana.

Distribuição geográfica: No Brasil, nos estados de Minas Gerais, Paraná, Rio de Janeiro, Santa Catarina e São Paulo (Coe-Teixeira, 1980).
Material examinado: Coleção da REMC: Sítio fazenda velha, s.d. (veg.), C.M.B. Correia s.n. (RB 292409).

Material adicional selecionado: Brasil: s.l., s.d. (fl.), Sello 399 (K). Minas Gerais: Ouro Preto, s.d. (fl.), s.c. (RB 48905).Paraná: Pilão de Pedra, Morretes, 4/12/1959 (fl.), G. Hatschbach s.n. (RB 318.800). Rio de Janeiro: Rio de Janeiro, Corcovado, s.d. (fr.), J.G. Kuhlmann s.n. (RB 19917). Santa Catarina: Bom Retiro, Paulo Lopes, 13/12/1973 (fl.), A. Bresolin 1068 (RB, FLOR). São Paulo: São Paulo, Instituto de Biociências, 22/11/1973 (fl.), R.M. Klein 10974 (RB); Tapecerica, Museu Florestal, 25/10/1943 (fr.), O. Vecchi 1190 (RB).

Comentários: Ocotea teleiandra tem distribuição restrita às regiões Sudeste e Sul, tendo seu limite norte em Minas Gerais e sul em Santa Catarina, sendo exclusiva da Floresta Pluvial Atlântica. Na Reserva, está representada por um indivíduo em área preservada.

Trata-se de uma espécie próxima de $O$. laxa, da qual difere por não apresentar folhas com domácias nas axilas de nervuras secundárias, flores com tépalas e anteras papilosas e pela cúpula cônica do fruto. Com distribuição nas regiões Sudeste e Sul do Brasil, ambas as espécies compartilham, além de algumas características morfológicass, a preferência de habitats e distribuição geográfica. Rohwer (1986), considera $O$. teleiandra um sinônimo de $O$. laxa, porém, com base nas diferenças apresentadas no fruto e com a observação de indivíduos de ambas as espécies em campo, propõe-se a revalidação de $O$. teleiandra.

Para complementar a descrição, foi utilizado o material com flores masculinas de $A$. Bresolin 1068, com flores femininas de s.c. (RB 48905) e fruto de O. Vecchi 1190.

Ocotea puberula (Rich.) Nees, Syst. Laurin., p. 472.1836.

Figura 10: B1-B13

Arvoreta de $3 \mathrm{~m}$ a árvore de $18 \mathrm{~m}$ alt., dióica, ramos angulosos, lenticelados, áureopubescentes; gemas apicais e axilares áureo- 


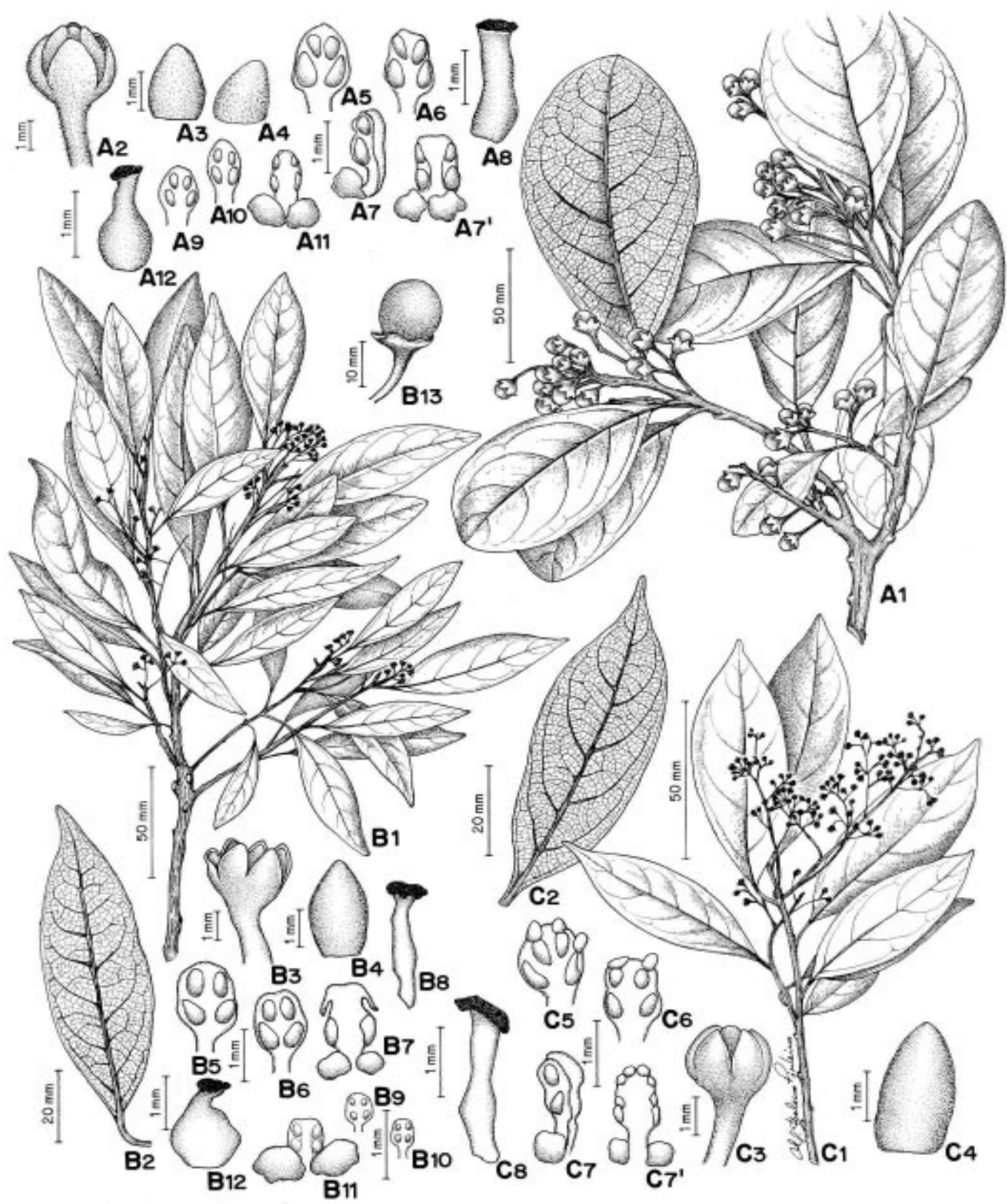

Figura 10 - A. Ocotea glaziovii Mez: A1 - Ramo frutífero; A2 - Flor masculina; A3 - Tépala externa; A4 - Tépala interna; A5 - Estame da série I; A6 - Estame da série II; A7-A7' - Estame da série III, vistas lateral e frontal, respectivamente; A8 - Pistilóide; A9 - Estaminódio da série I da flor feminina; A10 - Estaminódio da série II; A11 - Estaminódio da série III; A12 - Gineceu. B. Ocotea puberula (Rich.) Nees: B1 - Ramo florífero; B2 - Folha; B3 - Flor masculina; B4 - Tépala; B5 -Estame da série I; B6 - Estame da série II; B7 - Estame da série III; B8 - Pistilóide; B9 - Estaminódio da série I da flor feminina; B10 - Estaminódio da série II; B11 - Estaminódio da série III; B12 - Gineceu; B13 - Fruto. C. Ocotea pulchra Vattimo-Gil: C1 - Ramo florífero; C2 - Folha; C3 - Flor masculina; C4 - Tépala; C5 - Estame da série I; C6 - Estame da série II; C7-C7' - Estame da série III, vistas lateral e frontal respectivamente; C8 - Pistilóide. (A1, C.M.B. Correia 221; A2-A8, E. Pereira 4561 \& A.P. Duarte; A9-A12, C. de Almeida s.n. (RB 69512); B1-B2, H.C. Lima 3503; B3-B8, N. Imaguire 596; B9-B12, H C. Lima 3503; B13, C.M.B. Correia 201; C1-C8, R. Reitz \& R.M. Klein 568). 
seríceas. Folhas alternas em todo o ramo; pecíolo delgado, canaliculado, áureo-tomentoso; lâmina cartácea ou cartáceo-coriácea, lanceolada ou elíptica, 6,5-13,0 x2,5 -3,6 cm, base aguda, margem espessa, levemente decorrente, ápice agudo a acuminado; face adaxial brilhante, levemente áspera, glabra, sem pontoado glandular enegrecido, face abaxial opaca, áspera, pubérula principalmente ao longo das nervuras principal e secundárias; nervura principal impressa na face adaxial e proeminente na face abaxial; padrão de nervação broquidódromo, nervuras secundárias 7-9 pares alternos, ângulo de divergência $40^{\circ}-50^{\circ}$, nervuras intersecundárias compostas, nervuras terciárias não oblíquas em relação à nervura principal, reticulado denso; domácias ausentes. Inflorescência axilar, tirsóide, 3,5-8,0 cm compr., pubérula. Flores diclinas, tépalas ovais, subiguais, as externas semelhante às internas, ápice agudo, pubescente na face ventral; hipanto seríceo ou glabrescente. Flores masculinas: anteras com locelos superiores semelhantes aos inferiores, estames das séries I e II com filetes 0,06-0,09 cm compr., delgados, pilosos na base, anteras retangulares a quadrangulares, 0,12-0,11 cm compr., ápice obtuso a emarginado, glabras, introrsas; série III com filete $0,06-0,17 \mathrm{~cm}$ compr., delgado, piloso na base, par de glândula globosa na base, anteras retangulares $0,1-0,11 \mathrm{~cm}$ compr., ápice truncado, glabras, locelos superiores lateralmente introrsos, os inferiores lateralmente extrorsos; série IV estaminodial ausente; pistilóide presente, filiforme. Flores femininas: estaminódios de morfologia semelhante aos estames das flores masculinas, reduzidos; ovário globoso, glabro, estilete espesso, estigma discóide, trilobado. Fruto globoso, 1,2 - 1,8 cm compr., 1,0 - 1,5 cm compr., parcialmente envolvido por cúpula, $6,0-7,0 \mathrm{~cm}$ comp., 3,0 - 4,0 cm diâm., plana, de margem ondulada, tépalas persistentes na pré-antese, posteriormente decíduas; pedicelo frutífero espessado.

Nome popular: Canela-babosa, canelapimenta, louro-abacate.
Floração e frutificação: Coletada com flores em abril e agosto, com frutos em maio e setembro.

Habitat: No Brasil, ocorre na Floresta Pluvial Amazônica, Floresta Pluvial Atlântica e na Floresta Seca.

Distribuição geográfica: No Brasil, nos estados do Amapá, Amazonas, Bahia, Espírito Santo (Coe-Teixeira, 1980), Minas Gerais, Pará, Paraná, Rio de Janeiro, Rio Grande do Sul, Santa Catarina e São Paulo. Argentina (Rohwer, 1986), Guiana, México (Rohwer, 1986), Panamá, Paraguai (Coe-Teixeira, 1980) e Suriname.

Usos: Madeira cinzento-amarelada, tecido compacto e frouxo, mole, leve, com aroma de anis, própria para carpintaria e caixotaria. Usada também para fabrico de pasta para papel (Corrêa, 1926).

Material examinado: Coleção da REMC: Sítio Hum New Baccus, 07/08/1990 (fl., fr.), M.P.M. Lima 196 (RB); Ibidem, 13/09/1990 (fr.), C.M.B. Correia 201 (RB); Ibidem, 13/ 09/1990 (fr.), C.M.B. Correia 200 (RB); Ibidem, 02/06/1990 (fl.), H.C. Lima 3503 (RB); Nascente do Rio das Flores, 19/07/1990 (fr.), M. Leitman 392 (RB); Sítio Fazenda Velha, 21/07/1990 (veg.), T. Fontoura s.n. (RB 292347); Nascente do Rio das Flores, 25/ 05/1987 (fr.), G. Martinelli 12079 (RB); Sítio Sophronites, 03/06/1990 (fr.), H.C. Lima 3820 (RB).

Material adicional selecionado: Brasil: Amapá: Igarapé do Lago, 19/07/1951 (fr.), R.L. Fróes et G.A. Black 27512 (RB). Amazonas: Rio Negro, foz do Caiarí, terra firme perto da Serra Mauá, 01/10/1952 (fr.), R.L. Fróes 28817 (RB). Bahia: Porto Seguro, junto à fonte, 26/08/1961 (fl.), A.P. Duarte 6049 (RB); Ilhéus, Castelo Novo, Almada, 14/09/ 1944 (fl.), H. Vellozo 1071 (R). Minas Gerais: São José dos Lopes, Lima Duarte, Fazenda da Serra, 10/04/1994 (f1.), V.C. de Almeida n. I-95 (R). Pará: Belém, 23/04/1949 (fl.), $T$. Guedes 140 (RB). Paraná: Serra dos Dourados, próximo a Umuarama e Icaraíma, 19/01/ 1967 (fl.), G. Hatschbach 15750 et J.H. de 
Haas 4266 (RB); Curitiba, Juvevê, 10/09/1971 (fl.masc.), N. Imaguire 596 (RB). Rio de Janeiro: Petrópolis, Araras, morro Bolo de Milho, 27/04/1968 (fl.), D. Sucre 2784 et P.I.J. Braga 624 (RB, INPA MO, K, NY). Rio Grande do Sul: Porto Alegre, morro da Polícia, 03/06/1980 (fl.), L. Aguiar \& L. Martau 469 (RB). Santa Catarina: localidade de Xaxim, 27/08/1964 (fl.), R.M. Klein 5549 (RB, FLOR). São Paulo: Reserva Florestal da Bocaina, Posses, 07/05/1968 (fr), D. Sucre 2961 et al. (RB).

Argentina: Yaculika, a $3 \mathrm{~km}$ da Ponte Internacional, 21/11/1976 (fr.),A.R. Cuezzo 12041 c et al. (RB). Panamá: Província de Colon.: ao longo do Rio Guanche, $6 \mathrm{~km} \mathrm{~S}$ de Porto Belo, 10/12/1973 (fl.), M. Nee 8681 (HB). Paraguai: Floresta Yaguareté, 2408/1998 (fr.), Elsa Matilde Zardini et Anibal Vargas 43533 (RB, MO, PY). Suriname: along road from Zanderij to Kraka, $44.4 \mathrm{~km}$ from intersection with Zanderij Hwy., $0.5 \mathrm{~km}$ before bridge over Sabakoe Creek, 0525 . $30 \mathrm{~N}$ e 55.1130 W, 01/07/1994 (fr.), Randy Evans et George Lewis 1851 (RB, MO, NIH, NSF, USAID).

Comentários: Ocotea puberula ocorre, segundo Rohwer (1986), do México até a Argentina. No Brasil, ocorre na região Norte nos estados do Amazonas e Pará e na faixa atlântica desde o estado da Bahia até o Rio Grande do Sul. É uma espécie considerada generalista em termos de habitat, sendo encontrada nas mais variadas fisionomias. Na Reserva, é muito expressiva em área alterada, comportando-se como pioneira.

Caracteriza-se por apresentar folhas lanceoladas ou elípticas, face adaxial e abaxial áspera em material fresco ou seco, abaxial pubérula, padrão de nervação broquidódromo, frutos globosos, quando imaturos envolvidos por cúpula plana de margem ondulada com tépalas persistentes, e posteriormente decíduas.

Para complementar a descrição, foi utilizado o material com flores masculinas de $N$. Imaguire 596.
Ocotea pulchra Vattimo - Gil, Rodriguésia 30/ 31: 297.1956.

Figura 10: C1-C8

Árvore de 4-15 m alt., dióica, ramos subcilíndricos a angulosos, alvo-tomentosos, lenticelados. Folhas alternas em todo o ramo; pecíolo espesso, canaliculado, enegrecido, alvo-tomentoso; lâmina cartáceo-coriácea, lanceolada a elíptica, 4,5-9,5 x 1,8-3,4 $\mathrm{cm}$, base aguda, decorrente, margem espessa, plana a sub-revoluta, ápice agudo a curto-acumi-nado; face adaxial verde-claro, brilhante, sem pontoado glandular enegrecido, glabra, face adaxial opaca, áureo-pubérula a glabrescente; padrão de nervação broquidódromo, nervura secundária $5-8$ pares alternos, ângulo de divergência $45^{\circ}$ $50^{\circ}$, nervuras intersecundárias compostas, nervuras terciárias não oblíquas em relação à nervura principal, reticulado denso; domácias ausentes. Inflorescência panicula, 3,5 7,0 cm compr., áureo-tomentosa. Flores diclinas, tépalas, ovais a subglobosas, áureotomentosas, de ápice obtuso, subiguais, as externas semelhante às internas. Flores masculinas: anteras com locelos superiores semelhantes aos inferiores, estames das séries I e II com filetes 0,05-0,09 cm compr., anteras ovais, 0,07 -0,1 cm compr., ápice truncado ou obtuso, glabras, introrsas; serie III com filetes 0,05 -0,08 cm compr., glabros, par de glândula globosa na base, extrorsas, anteras subretangulares, 0,09-0,1 cm compr., ápice truncado, glabras; série IV estaminodial ausente; pistilóide presente, filiforme. Flores femininas e frutos não observados.

Floração: Coletada com flores mascu-linas em maio e junho, setembro e outubro.

Habitat: Ocorre na Floresta Pluvial Atlântica Montana e Baixo-montana.

Distribuição geográfica: No Brasil, nos estados do Rio de Janeiro, Santa Catarina e São Paulo.

Material examinado: Coleção da REMC: Sítio Sophronites, nascente do Rio das Flores, 06/06/1988 (veg.), R. Guedes s.n (RB 292225); Sítio Fazenda Velha, Rio Macaé, 04/ 
06/1990 (veg.); H.C. Lima s.n. (RB 292373); Nascente do Rio das Flores, s.data (veg.), $R$. Guedes s.n (RB 292371).

Material adicional selecionado: Brasil: Santa Catarina: Itajaí, morro da Fazenda, 28/ 04/1954 (fl.), P.R. Reitz et R. M. Klein 1815 (RB); Itajaí, R. Reitz et R.M. Klein 1855 (RB); Blumenau, Morro Spitzkopf, 23/04/1953 (fl.), R. Reitz et R.M. Klein 568 (HB, HBR); Morro da Fazenda, Itaguaí, 50 ms.m, R. Reitz et R.M. Klein 1834 (RB). São Paulo: São Paulo, Jardim Botânico, 01/07/1932 (fl.), F.C. Hoehne s.n. (HB 29758, SP).

Comentários: Ocotea pulchra ocorre na região Sudeste, nos estados do Rio de Janeiro e de São Paulo, e na região Sul, no estado de Santa Catarina, exclusivamente na Floresta Pluvial Atlântica Montana e Baixo-montana. $\mathrm{Na}$ Reserva, ocorre em áreas preservadas, com pequeno número de indivíduos e, até o momento, suas flores femininas e frutos são desconhecidos para a ciência.

Os espécimens coletados em Macaé de Cima conferem com o material de Santa Catarina descrito por Vattimo-Gil (1956a). Rohwer (1986) juntou esta espécie com outras vinte em $O$. lancifolia. São necessários estudos futuros para uma melhor avaliação da amplitude morfológica e geográfica dos táxons envolvidos.

Espécie muito próxima de $O$. martiana, da qual difere por apresentar folhas com nervuras da face adaxial característicamente sulcadas (Vattimo-Gil, 1956a) e por apresentar reticulado visivelmente mais denso.

Para complementar a descrição, foi utilizado o material com flores masculinas de $R$. Reitz \& Klein 568.

Ocotea glaziovii Mez, Jahrb. Bot. Gart. Berlin 5:281. 1889.

Figuras 10: A1-A12

Árvore de 4 - 8 m alt., dióica, ramos angulosos, glabrescentes a áureo-tomentosos; gemas axilares e apicais densamente áureoseríceas. Folhas alternas em todo o ramo; pecíolo canaliculado, áureo-tomentoso ou gla- bro; lâmina cartáceo-coriácea, obovada ou elíptica, 9,5-24,6 x 5,6-10,5 cm, base cuneada, decorrente, margem espessa, sub-revoluta, ápice curto-acuminado ou obtuso, glabra nas duas faces; nervura principal impressa na face adaxial e proeminente na face abaxial, sem pontoado glandular enegrecido; padrão de nervação broquidódromo, nervuras secundárias 5 - 7 pares alternos, ângulo de divergência $40^{\circ}-60^{\circ}$, nervuras intersecundárias compostas, nervuras terciárias não oblíquas em relação à nervura principal, reticulado denso; domácias ausentes. Inflorescência tirsóide, $8,5-16,5 \mathrm{~cm}$ compr., áureo-tomentosa. Flores diclinas, tépalas oblongo-lanceoladas, ápice obtuso, áureo-tomentosas na face dorsal e ventral, desiguais, externas com comprimento menor que as internas; hipanto viloso. Flores masculinas: estames das séries I e II com filetes 0,08 - 0,1 cm compr., delgados quase do mesmo comprimento que as anteras, antera oval, 0,12 - 0,15 cm compr., glabra, ápice agudo, locelos superiores menores que os inferiores, introrsos; série III com filetes $0,1 \mathrm{~cm}$ compr., delgados, par de glândula globosa na base, anteras ovais 1,25 mm compr., locelos superiores lateralmente extrorsos e inferiores frontalmente extrorsos, glabros; série IV estaminodial ausente; pistilóide presente, filiforme. Flores femininas: estaminódios de morfologia semelhante aos estames das flores masculinas, reduzidos; ovário sub-globoso, glabro, estilete cilíndrico, estígma discóide. Fruto sub-globoso a globoso, 0,6 - 0,8 cm diâm., 0,5 - 0,7 cm compr., parcialmente envolvido por cúpula obcônica, tépalas persistentes; pedicelo frutífero espessado.

Nome popular: Canela-amarela.

Floração e frutificação: Coletada com flores em março, abril, maio, junho, julho e com frutos em setembro novembro e dezembro.

Habitat: Ocorre na Floresta Pluvial Atlântica Baixo-montana e Montana, Floresta Seca e Cerrado.

Distribuição geográfica: No Brasil, nos estados de Distrito Federal (Nicolau, 1999), Espírito Santo (Nicolau, 1999), Goiás (Rohwer, 
1986), Minas Gerais, Paraná (Nicolau, 1999),

Rio de Janeiro, Santa Catarina (Nicolau, 1999)

e São Paulo (Coe-Teixeira, 1980).

Material examinado: Coleção da REMC: Sítio Huw Baccus, 13/09/1990 (fr.), C.M.B. Correia 221 (RB).

Material adicional selecionado: Brasil: Minas Gerais: Entre os municípios de Curvelo e Jequitai, s.d. (fl.), M. Gomes s.n. (R10296); Tombos, fazenda Cachoeira, 12/07/ 1935 (fr.), M. Barreto 1571 (R). Rio de Janeiro: s.d. (fl.), Glaziou 1879 (G); Rio de Janeiro, Tijuca, s.d. (fl.), Glaziou 12134 (K); Ibidem, estrada do Sumaré, 01/02/1929 (fl.), Glaziou 6666 (RB); Ibidem, estrada do Cristo, mata do Pai Ricardo, 09/06/1941 (fl.), $C$. de Almeida s.n. (RB 69512); Ibidem, Floresta da Tijuca, entre a Mesa do Imperador e Alto da Boa Vista, 26/03/1959 (fl.), E. Pereira 4561 et A.P. Duarte (RB); Ibidem, Estrada da Tijuca em direção as Paineiras, 21/08/1931 (fl.), J.G. Kuhlmann 527 (RB); Ibidem, Alto da Boa Vista, 14/03/1881 (fl.), Glaziou et al. 5573 (R).

Comentários: Ocotea glaziovii apresenta distribuição nas regiões Centro-oeste, Sudeste e Sul, ocorrendo no Cerrado de Goiás e do Distrito Federal, na Floresta Seca de Minas Gerais e na Costa Atlântica tem seu limite norte no Rio de Janeiro e sul em Santa Catarina, habitando a Floresta Pluvial Atlântica Baixo-montana e Montana. Foi coletada na Reserva em área preservada, sendo a segunda espécie de maior freqüência.

Diferencia-se das demais espécies da família, na Reserva, por apresentar folhas obovadas ou elípticas, reticulado denso e pequenos frutos parcialmente envolvidos por cúpula com tépalas persistentes.

Para complementar a descrição, foi utilizado o material com flores masculinas de A.P. Duarte \& E. Pereira 4561 e com flores femininas de C. de Almeida s.n. (RB 69512).

Ocotea spixiana (Nees) Mez, Jahrb. Bot. Gart. Berlin 5: 260. 1889

Figura 7: A1-A9
Arvoreta ca. de $5 \mathrm{~m}$ alt., dióica, ramos subcilíndricos a angulosos em direção ao ápice, leve a denso ferrugíneo-tomentosos; gemas apicais e axilares ferrugíneo-vilosas, envolvidas por invólucro coriáceo. Folhas alternas em todo o ramo; pecíolo largo-achatado, áureo-tomentoso; lâmina coriácea, obovada ou oblongolanceolada, 6,7-11,5 × 2,8-4,8 cm, base aguda, decorrente, margem espessa, ápice agudo a acuminado; face adaxial brilhante, glabrescente a tomentosa, principalmente sobre nervuras principal e secundárias, sem pontoado glandular enegrecido, face abaxial ferrugíneotomentosa ou ferrugíneo-pubérula principalmente ao longo das nervura principal e secundárias; nervura principal plana na face adaxial e proeminente na face abaxial; padrão de nervação camptódromo, nervuras secundárias 4 -6 pares alternos, ângulo de divergência $40^{\circ}-50^{\circ}$, nervuras inter-secundárias compostas, reticulado denso; domácias ausentes. Inflorescência axilar, tirsóide, 3,0 -6,3 cm compr., multiflora, ferrugíneo-tomentosa. Flores diclinas, ferrugíneo-tomentosas, tépalas ovais, subiguais, as externas semelhantes às internas; hipanto piloso. Flores masculinas: estames das séries I e II com filetes 0,1 -0,11 cm compr., pilosos na parte frontal, antera oval, 0,12-0,13 cm compr., ápice obtuso, papilosa, introrsa, locelos superiores menores que os inferiores; estames da série III com filetes pilosos, 0,15 $0,16 \mathrm{~cm}$ compr., mais delgados e longos que as anteras, com par de glândula globosa na base, anteras ovóides a sub-retangulares, 0,12-0,14 cm compr., ápice truncado, lateralmente extrorsas, papilosas, extrorsas; série IV estaminodial presente, estaminódios filiformes; pistilóide presente, elíptico, 0,3 cm compr., denso piloso, estígma sub-triangular. Fruto obovóide ou sub-globoso, 1,7 -2,2 cm compr., 1,5 - 1,8 cm diâm., envolvido por cúpula $0,5-0,6 \mathrm{~cm}$ compr., 1,0 -1,2 cm diâm., rasa, crassa, ferrugíneo-velutina, tépalas persistentes; pedicelo frutífero espesso, estriado.

Nome popular: Canelão.

Floração e frutificação: Coletada com flores em abril e maio, com frutos em novembro. 
Habitat: Ocorre na Floresta Pluvial Atlântica Montana e Baixo-montana, Floresta Seca e no Cerrado.

Distribuição geográfica: No Brasil, nos estados da Bahia, Distrito Federal, Goiás, Mato Grosso do Sul, Minas Gerais, Rio de Janeiro. Material examinado: Coleção da REMC: Nascente do rio das Flores, 26/11/1986 (veg.), G. Martinelli 11931 (RB).

Material adicional: Brasil: Bahia: Divisa com o estado de Minas Gerais, estrada BR-4, 02/06/1967 (fl.), A.P. Duarte 10420 (RB, CEPEC, INPA, K, NY). Distrito Federal: Brasília, Horto do Guará, 10/04/1962 (fl.), E.P. Heringer 8913 (RB, UB). Goiás: Alto Paraíso, km 31 da estrada Alto Paraíso/São João da Aliança, 29/ 04/2000 (fl.), B.A.S. Pereira et D. Alvarenga 3045 (IBGE, HB). Mato Grosso do Sul: Naviraí, entre Naviraí e Ivinhoma, lat. $22^{\circ} 23^{\prime}$ 'S e long. 54 $02^{\prime}$ ' W, 20/08/1980 (fr.), $P$. Furtado 13 (RB). Minas Gerais: Paracatu, coordenadas: $17^{\circ} 20^{\prime}$ S e $47^{\circ} 20^{\prime} \mathrm{W}, 06 / 05 / 1997$ (fl.), B.A.S. Pereira et D. Alvarenga 3358 (IBGE, HB). Rio de Janeiro: Teresópolis, fazenda Boa Fé, picada Davis, 09/04/1943 (fl.), H. Vellozo 384 (R, M).

Comentários: Ocotea spixiana distribui-se nas regiões Centro-oeste, Nordeste e Sudeste, onde ocorre no Cerrado de Goiás e Distrito Federal, na Floresta Seca de Minas Gerais e na costa atlântica na Floresta Atlântica Montana e Baixo-montana da Bahia até o Rio de Janeiro, exceto no estado do Espírito Santo. Foi coletada apenas uma vez na Reserva, em área preservada.

Diferencia-se das demais espécies da família, pelas folhas obovadas a oblongo-lanceoladas, coriáceas, pilosidade ferrugíneo-tomentosa na face abaxial e pelos frutos envolvidos por cúpula com indumento ferrugíneo-velutino, sedoso ao tato e tépalas persistentes.

Para complementar a descrição, foi utilizado o material com flores masculinas de B.A.S. Pereira et D. Alvarenga 3358 e fruto de P. Furtado 13.

\section{CONSIDERAÇÕES FINAIS}

Foram coligidas para a Reserva Ecológica de Macaé de Cima 33 espécies, subordinadas a nove gêneros, que representam cerca de $30 \%$ e $50 \%$, respectivamente, do total estimado para o estado do Rio de Janeiro. Apesar dos esforços concentrados da equipe de coleta do Programa Mata Atlântica do Instituto de Pesquisas do Jardim Botânico do Rio de Janeiro, realizados nos últimos dez anos, além dos esforços de coletores do passado, tais como Gardner e Glaziou, provavelmente o número encontrado de espécies não representa ainda o total esperado, em virtude da Reserva apresentar locais de difícil acesso e pouco explorados. Alguns exemplares indeterminados na coleção atual, pela ausência de material florífero e/ou frutífero, não puderam ter sua identidade reconhecida, podendo até representar novos táxons para a ciência.

$\mathrm{Na}$ Reserva, a família é caracterizada pela dominância de espécies com baixa densidade populacional, habitando preferencialmente ambientes em fases sucessionais mais avançadas, onde representa a segunda família em riqueza de espécies, com algumas destas destacando-se pela alta freqüência (Lima \& Guedes-Brunni, 1997), como, por exemplo, Beilschmiedia rigida e Ocotea divaricata. Inventários também realizados em matas de terra firme na Amazônia brasileira apontam as Leguminosae, Lecythidaceae, Sapotaceae, Burseraceae, Chrysobalonaceae, Moraceae e Lauraceae como famílias arbóreas com alta diversidade e grande porcentagem de espécies, com baixa densidade, presentes no dossel das matas primárias, padrões estes já bem estabelecidos em análises ao nível de família (Oliveira, 2000).

No Rio de Janeiro, Vaz (1992) indica a família Lauraceae como uma das maiores em diversidade de gêneros (13), junto com Leguminosae, Euphorbiaceae e Rubiaceae. Segundo dados de levantamentos realizados na floresta atlântica do estado.

$\mathrm{O}$ gênero Ocotea destaca-se por ser o 
maior em número de espécies (18), o que corrobora o estudo de Vattimo-Gil (1959a) que aponta a Floresta Atlântica, nas regiões Sul e Sudeste, como um dos centros de diversidade do gênero, sendo ele um dos mais característicos neste ecossistema e na flora brasileira em geral, mas que, apesar disto, carece de uma revisão atualizada. Com outros gêneros da família ocorre o mesmo fato, como exemplo, em Endlicheria, dificultando a identificação dos táxons, aliado à complexidade morfológica, a inúmeros problemas taxonômicos e nomenclaturais, além do fato das coleções contarem com um número considerável de espécimes, somente em estado vegetativo, oriundo, em geral, de inventários fitossociológicos.

No que se refere à estratificação, constata-se a preferência de algumas espécies por certos ambientes na Reserva. Nos topos dos morros, arvoretas de Ocotea indecora e Ocotea divaricata são freqüentes, e entre as árvores emergentes são expressivos os indivíduos de Beilschmiedia rigida, Ocotea glaziovii entre outros (Lima \& Guedes-Brunni, 1997).

A análise da distribuição geográfica das espécies ocorrentes na Reserva revela uma concentração na faixa neotropical, sendo o maior número de espécies circunscritas ao território brasileiro. No território brasileiro, a região Sudeste apresenta a maior concentração de espécies e o habitat preferencial é a Floresta Atlântica. O padrão mais restrito é representado apenas por Ocotea domatiata, considerada endêmica da Reserva Ecológica de Macaé de Cima e, portanto, do Estado do Rio de Janeiro. Ampliou-se com este trabalho a distribuição geográfica até então conhecida das espécies de Cinnamomum glaziovii e Ocotea urbaniana.

Entre as contribuições importantes do ponto de vista taxonômico e morfológico, destacam-se a revalidação de Ocotea domatiata, Ocotea pulchra e Ocotea teleiandra, a complementação da descrição de Ocotea domatiata e Cinnamomum glaziovii, cujos frutos são conhecidos e descritos pela primeira vez neste trabalho. Vale ressaltar a importância do uso da nervação foliar e dos tipos de inflorescências como caracteres diagnósticos para a identificação dos gêneros e espécies.

Lauraceae é também considerada uma das famílias de maior importância econômica da Floresta Atlântica. Em virtude da boa qualidade de sua madeira e do alto valor que alcançam seus óleos essenciais no comércio, tem sido intensamente explorada ao longo dos anos, colocando em risco a preservação de suas espécies. Como medida de proteção, algumas delas podem ser indicadas para a recomposição florística, como parte das práticas de manejo e para enriquecimento de florestas em recuperação.

\section{AGRADECIMENTOS}

Durante a execução deste trabalho, muitas pessoas e instituições contribuíram de diferentes formas. Meus sinceros agradecimentos a todas elas, especialmente:

À Dra. Regina Helena Potsch Andreata, pela dedicada orientação e apoio em todas as etapas da realização deste trabalho.

À Dra. Cecília Guimarães Costa, Pesquisadora do Instituto de Pesquisas Jardim Botânico do Rio de Janeiro, que, sempre muito atenciosa, auxiliou na análise dos padrões de nervação das folhas.

Ao Paulo Rogério Ferreira Dias, técnico em Biologia do Ministério do Meio Ambiente - Ciência e Tecnologia e responsável pelo laboratório de Botânica Estrutural, pelo auxílio no processo de diafanização e fotografias das folhas.

Ao Dr. José Fernando Baumgratz, Pesquisador do Instituto de Pesquisas Jardim Botânico do Rio de Janeiro, pelo auxílio na difícil tarefa de interpretação das inflorescências.

Ao Dr. João Batista Baitello, do Instituto Florestal de São Paulo, pelo auxílio na identificação de alguns materias de difícil determinação e na aquisição de literatura especializada. 
À Dra. Graziela M. Barroso, pelo esclarecimento de dúvidas e pelo carinho e incentivo, que a todos transmite.

Ao Instituto de Pesquisas Jardim Botânico do Rio de Janeiro, pelo uso de suas instalações.

À Coordenação doPrograma Mata Atlântica, como a todos seus integrantes, pelo agradável convívio, apoio logístico e livre acesso a informações e a sua coleção.

Ao meu grande amigo Luiz Fernando, pela tradução de inglês para o Abstract.

Ao Rosembergue Silva, técnico em informática, pelo auxílio na impressão das imagens e ilustrações.

Aos funcionários da Biblioteca Barbosa Rodrigues, pela atenção que sempre me dispensaram, especialmente a Milton Ferreira Botelho, Tânia Lúcia Rezende, Tânia Riccieri, Nilton da Silva Filho e Maria de Fátima Virbicaro Ramos.

À Coordenadoria de Aperfeiçoamento de Pessoal de Nível Superior (CAPES), pela concessão da bolsa de estudo.

A todos os curadores de herbário que tão bem me receberam e pelo empréstimo ou doações de materiais para estudo.

À Coordenação do curso de Pós-Graduação em Ciências Biológicas (Botânica) da Universidade Federal do Rio de Janeiro, Museu Nacional.

\section{REFERÊNCIA BIBLIOGRAFICA}

Allen, C.K. 1945. Studies in the Lauraceae VI. Preliminary survey of the Mexican and Central American species. Journal of the Arnold Arboretum 24: 280-434.

1966. Notes on Lauraceae of Tropical America I. The generic status of Nectandra, Ocotea, Pleurothyrium. Phytologia 13 (3): 221-231.

Andreata, R.H.P. 1997. Revisão das es-pécies brasileiras do gênero Smilax Linnaeus (Smilacaceae). Pesquisas, Botânica, 47: 7-244.

Rodriguésia 53 (82): 59-121. 2002
Araújo, I.A. de. 1994. Beilschmiedia Nees (Lauraceae) do Estado do Rio de Janeiro. Dissertação de mestrado. Universidade Federal do Rio de Janeiro, Rio de Janeiro. 59p.

Aublet, J.B.F. 1775. Histoire des plantes de la Guiane françoise. Paris: P. F. Didet, xxxii+976+160 p.,p1. 1-392 (p. 780-784, pl. 310).

Baitello, J.B. \& Aguiar, O.T. 1982. Flora Arbórea da Serra da Cantareira (São Paulo). Silvicultura em São Paulo 16 (1): 582-590.

\& Coe-Teixeira, B. 1987. Flora Fanerogâmica do Parque Estadual das Fontes do Ipiranga (São Paulo, Brasil): Lauraceae. Hoehnea 14: 63-74.

Barroso, G.M. et al. 1978. Sistemática de Angiospermas do Brasil. v.1. Ed. Universidade de São Paulo, São Paulo. 255p. ilust.

Barroso, I.S. 1949. Chave para determinação de gêneros indígenas e exóticos da Família Lauraceae no Brasil. Rodriguésia 12 (24): 137-146, 2 tabs.

Bentham, G. 1880. Laurineae. In: Bentham, G. \& Hooker, J.D. Genera plantarum v.3, part1, p. 146-168. Lovell Reeve \& Co., Williams \& Norgate, London.

Bernardes, L.N.C. 1952. Tipos de clima do estado do Rio de Janeiro. Revista Brasileira de Geografia 14 (1): 57-80.

Bernardi, L. 1962. Lauráceas. Talleres Graficos Universitarios. Mérida. 355p., ilust.

Cante, T. 1988. O móvel do século XIX no Brasil. CGPM. Rio de Janeiro. 190 p.

Coe-Teixeira, B. 1963. Lauráceas do Estado de São Paulo I. Beilschmiedia, Endlicheria e Aniba. Boletim do Instituto de Botânica de São Paulo 1: 129, 4 est.

1964. Lauráceas do Estado de São Paulo. III. Nectandra. Anais do $\mathbf{1 5}^{\circ}$ Congresso da Sociedade Botânica do Brasil. Sociedade Botânica do Brasil, 
Porto Alegre. p: 119-123. 1965. Lauráceas do Estado de São Paulo II: Cryptocarya. Arquivos de Botânica do Estado de São Paulo 4 (1): 1-9. 1975. Lauráceas do Estado de São Paulo: Persea. Hoehnea 5: 27-45. 1980. Lauráceas do gênero Ocotea do Estado de São Paulo. Rodriguésia 32 (52): 55-190.

Corrêa, P. 1926. Dicionário das plantas úteis do Brasil. Ministério da Agricultura. Instituto Brasileiro de Desenvolvimento Florestal.

Foster, A.S. 1974. Practical Plant Anatomy. R.E.K. Publishing Co. Huntington, New York and London.

Guedes-Bruni, R.R. 1998. Composição, estrutura e similaridade florística de dossel em seis unidades de Mata Atlântica no Rio de Janeiro. Tese de doutorado. Instituto de Biociências, Universidade de São Paulo, São Paulo. $231 \mathrm{p}$.

Pessoa, S.V.A. \& Kurtz, B. 1997. Florística e estrutura do componente arbustivo-arbóreo de um trecho preservado de floresta montana na Reserva Ecológica de Macaé de Cima. In: Lima, H.C. de \& GuedesBruni, R.R (eds.). 1997. Serra de Macaé de Cima: Diversidade Florística $e$ Conservação em Mata Atlântica. Jardim Botânico do Rio de Janeiro, Rio de Janeiro. p. 127-145.

Hickey, L.J. 1973. Classification of the architecture of dicotyledonous leaves. American Journal of Botany 60 (1): 17-33.

Holmgren, P.K.; Holmgren, N.H \& Barnett, L.C. 1990. Index Herbariorum. $8^{\mathrm{a}}$ ed. Internacional Association for taxonomy, New York. 693p.

Jussieu, A.L. 1789. Genera plantarum secundum ordines naturales disposita. Paris: Herissant et Barrois, Lxxii+498p.
Klein, R.M., 1978. Contribuição ao conhecimento da flora e da vegetação do vale do Itajaí. Santa Catarina. Tese (Doutorado). Instituto de Biociências, Universidade de São Paulo. 412p.

Koop, L.E. 1966. A Taxonomic revision of the genus Persea in the western hemisphere (Perseae- Lauraceae). Memoirs of the New York botanical garden 14: 1-117.

Kostermans, A.J.G.H. 1936. Revision of the Lauraceae I. Recueil des Travaux Botanisques Néerlandais 33: 719-757. 1937. Revision of the Lauraceae II. The genera Endlicheria, Cryptocarya (American species) and Licaria. Recueil des Travaux Botaniques Néerlandais 34:500-605.

1938a. Revision of the Lauraceae III. The genera Aiouea, Systemonodaphne, Urbanodendron, Mezilaurus; additions and corrections to Licaria and Cryptocarya. Recueil des Travaux Botaniques Néerlandais 35: 56-129.

1938b. Revision of the Lauraceae V. A monograph of the genera: Anaueria, Beilshmiedia (American species) and Aniba. Recueil des Travaux Botaniques Néerlandais 35: 834-931.

1952. A historical survey of the Lauraceae. Journal Scientific Research 1 : 83-95.

1953. Notas sobre as Lauraceae Lauroideae Sul Americanas. Boletim Técni-co do Instituto Agronômico do Norte 27-30: 49-75.

1957. Lauraceae. Reinwardtia 4 (2): 193-256.

1961. Lauraceae. Reinwardtia 6 : 21-152.

1970/1974. Materials for revision of Lauraceae III. Reinwardtia 8: 21196.

Kubitzki, K. \& Renner, S. 1982. Lauraceae I (Aniba and Aiouea). Flora Neotropica 31. New York Botanical Garden, New York. 124p.

Rodriguésia 53 (82): 59-121. 2002 
Lauraceae Jussieu na Reserva Ecológica de Macaé de Cima, Município de Nova Friburgo,

Rio de Janeiro, Brasil

Kurtz, B.C. 1994. Composição florística e estrutura do estrato arbóreo de um trecho de Mata Atlântica situado na Estação Ecológica Estadual de Paraíso, Município de Cachoeiras de Macacu, Rio de Janeiro. Dissertação de mestrado. Universidade Federal do Rio de Janeiro, Rio de Janeiro.

Leitão Filho, H.F. 1986. Consideração sobre a composição florística das matas brasileiras. Boletim do Instituto de Pesquisas Florestais 12: 21-32.

. 1987. Considerações sobre a

florística de florestas tropicais e subtropicais do Brasil. Publicação do Instituto de Pesquisas Ambientais IPEF 35: 41-45.

Lima, H.C. de \& Guedes-Bruni, R.R (eds.). 1997. Serra de Macaé de Cima: Diversidade Florística e Conservação em Mata Atlântica. Jardim Botânico do Rio de Janeiro, Rio de Janeiro. 346p.

Lima, M.P.M. de \& Guedes-Bruni, R.R. (orgs.). 1994. Reserva Ecológica de Macaé de Cima, Nova Friburgo, RJ: Aspectos Florísticos das Espécies Vasculares. v.1. Jardim Botânico do Rio de Janeiro, Rio de Janeiro. 404p.

Lima, M.P.M. de \& Guedes-Bruni, R.R. (orgs.). 1996. Reserva Ecológica de Macaé de Cima, Nova Friburgo, RJ: Aspectos Florísticos das Espécies Vasculares. v.2. Jardim Botânico do Rio de Janeiro, Rio de Janeiro. 465p.

Lindmam, C.A.M. 1906. A vegetação no Rio Grande do Sul. Porto Alegre, Typografia Livraria Nacional. p. 157-161.

Linnaeus, C. 1753. Species plantarum. Holmiae, xii+1231 p.

Lorea-Hernández, F.G. 1998. A systematic revision of the neotropical species of Cinnamomum (Lauraceae). Tese de Doutorado. University of Missouri, St. Louis. 98p.

Meisner, C.F. 1864. Lauraceae. In: De Candolle, A. Prodromus systematis naturalis regni vegetabilis. v.15, part. 1, p. 1-260.

. 1866. Lauraceae. In: Martius, C.F.P. von et al. Flora Brasiliensis. v.5, pt. 2. Muchen, Wien Leipzig.

Mez, C. 1889. Lauraceae Americanae. Jahrbuch des Königlichen botanischen Gartens und des botanichen Museums zu. Berlin v. 5, p. $1-556$.

Moraes, P.L.R. \& Paoli, A.A.S. 1995. Dispersão e germinação de sementes de Cryptocarya moschata Nees \& Martius ex Nees, Ocotea catharinensis Mez e Endlicheria paniculata (Sprengel) Macbride (Lauraceae). Arquivos de biologia e tecnologia 38: 1119-1129.

Moraes, P.L.R. \& Paoli, A.A.S. 1996. Morfologia de frutos e sementes de Cryptocarya moschata Nees \& Martius ex Nees, Ocotea catharinensis Mez e Endlicheria paniculata (Sprengel) Macbride (Lauraceae). Arquivos de biologia e tecnologia 38: 1119-1129.

Nees, C.G.D.1833. Revision laurinarum ab Sellowio in Brasilia collectarum et iam in Herbario Regio Berolinensi asservatarum. Linnaea 8 (1): 37. 1836. Systema Laurinarum. $8^{\mathrm{a}}$ ed, Cum Magna, Berlin Veit. 720 p.

Nicolau, S.A. 1999. A família Lauraceae na Serra da Juréia, Iguape, SP, Brasil. Dissertação de mestrado. Instituto de Biociências, Universidade de São Paulo, São Paulo. 106p.

Nimer, E. 1989. Climatologia do Brasil. Fundação Instituto Brasileiro de Geografia e Estatística - IBGE, Rio de Janeiro. 421p.

Nishida S. 1999. Revision of Beilschmiedia (Lauraceae) in the Neotropics. Annals Missouri Botanical Garden 86: 657701.

\& Christophel D.C. 1999. Leaf anatomy of Beilschmiedia (Lauraceae) in the Neotropics. Nature and Human 
Activities 4: 9-43.

Oliveira, A. 2000. Inventários qualitativos de árvores em matas de terra firme Amazônia brasileira. Acta Botânica Amazônica 30 (4): 543-567.

Pax, F. 1894. Lauraceae. In: Engler \& Prantl. Die natürlichen Pflanzenfamilien v. 3, part. 2, p. 106-126, Leipzig.

Quinet, A. 2000. Lauraceae. In: Maio, F.R. Di et Silva, M.B.R. Espécies ameaçadas de extinção no Município do Rio de Janeiro: Flora e Fauna. Secretaria Municipal de Meio Ambiente, Rio de Janeiro. 68p. ilust.

Richter, H.G. 1980. Occurrence, morphology and taxonomic implications of crystalline and siliceous inclusions in the secondary xylem of the Lauraceae and related families. Wood Science and Technology 14: 35-44.

1981. Wood and bark anatomy of Lauraceae I. Aniba Aublet. Iawa Bulletin n.s., 2 (2-3): 79-87.

1985. Wood and bark anatomy of Lauraceae II. Licaria Aublet. IAWA Bulletin n.s., 6 (3): 187-199.

Rizzini, C.T. 1977. Sistematização terminológica da folha. Rodriguésia 42: 103 126.

1979. Tratado de Fitogeografia do Brasil, Aspectos Sociológicos e Florísticos. $2^{\circ}$ ed, EDUSP/HUCITEC, São Paulo.

Rodrigues, H.C. 1996. Composição Florística e Estrutura Fitossociológica de um trecho de Mata Atlântica na Reserva Biológica do Tinguá, Nova Iguaçu, Rio de Janeiro. Dissertação de mestrado. Universidade Federal do Rio de Janeiro, Rio de Janeiro.

Rohwer, J.G. 1986. Prodromus einer Monographie der Gattung Ocotea Aubl. (Lauraceae), sensu lato. Mitteilungen aus dem Institut fur Allgemeine Botanik Hamburg 20. 278p. 1993a. Lauraceae: Nectandra. Flora Neotropica, Monograph 60. New York Botanical Garden, New York. 332p., ilust. 1993b. Lauraceae. In: Kubitzki, K., Rohwer, J.G. \& Bittrich, V. (eds.). The Families and Genera of Vascular Plants II. Springer-Verlag, Berlin. p: 366391.

, Richter, H.G. \& Werff, H. van der. 1991. Two new genera of neotropical Lauraceae and critical remarks on the generic delimitation. Annals of the Missouri Botanical Garden 78: 388 400.

Rottboell, C.F. 1778. Descriptiones plantarum surinamensium. Acta literaria universitatis hafniensis 1: 269-282, Copenhagen.

Sangirardi, Jr. 1984. Botânica fantástica: plantas da mitologia, religião, magia. Ed. Brasiliense, São Paulo. 113p, ilust.

Santos, M. \&Almeida, S.L. 1995. Contribuição ao estudo morfológico e anatômico das domácias em espécies de Ocotea Aubl. (Lauraceae) da região sul do Brasil. Ínsula 24: 73-97.

\& Oliveira, P.L. 1989. Domácias no gênero Ocotea Aubl. (Lauraceae). Ínsula 19: 13-26.

Siqueira, M.F. de. 1994. Análise florística e ordenação de espécies arbóreas da Mata Atlântica através de dados binários. Dissertação de mestrado. Universidade Estadual de Campinas, Campinas, 143p.

Strittmater, C. G. D. 1973. Nueva técnica de diafanización. Boletin da Sociedade Ar-gentina de Botânica, 15 (1): 126129.

Thornthwaite, C.W. \& Mather, J.R. 1955.The water balance. New Jersey. Laboratory of climatology. Usher, M.B. 1986. Widlife conservation evaluation: attributes, criteria and values. In: Usher, M.B. (ed.). Widlife conservation evaluation. London. Chapman \& Hall Publ. p: 3-44.

Rodriguésia 53 (82): 59-121. 2002 
Vattimo-Gil, I. de. 1956a. O gênero Ocotea Aubl. no sul do Brasil I. Espécies de Santa Catarina e do Paraná. Rodriguésia 18-19 (30-31): 265-350.

1956b. Nota prévia sobre espécies de Ocotea. Arquivos do Serviço Florestal 10: $109-123$. . 1956c. Lauraceae do Itatiaia. Rodriguésia 18-19 (30-31): 39-86.

1957. Lauraceae do Rio de Janeiro. Arquivos do Jardim Botânico do Rio de Janeiro 15: 115-144.

. 1958. Seis novas espécies brasileiras do gênero Ocotea. Arquivos do Serviço Florestal 10: 109-123.

1959a. Flora da Cidade do Rio de Janeiro (Lauraceae). Rodriguésia 21/ 22 (33-34): 157-176, 2 pls.

1959b-1961. O gênero Ocotea

Aubl. dos Estados de São Paulo e Rio Grande do Sul. Apêndice: notas sobre o gênero Cinnamomum Boehm, no Brasil. Arquivos do Jardim Botânico do Rio de Janeiro 17: 199-226.

. 1960-1961b. O gênero Ocotea Aubl. no Nordeste do Brasil. (Lauraceae). Rodriguésia 23/24 (35): 241-251, 1 pl. 1966a. Lauraceae do Estado da Guanabara. Rodriguésia 25 (37):75113, 9 pls., 223 figs.

1966b. Notas sobre o gênero Cryptocarya R.Br. no Brasil (Lauraceae). Rodriguésia 25 (37): 219-231.

. 1976. Estudos sobre Ocotea Aubl., Phyllostemonodaphne Kosterm. e Licaria Aubl. (Lauraceae). Rodriguésia 28 (41): 121-127.

1978a. Contribuição ao conhecimento da distribuição geográfica das Lauraceas I. Rodriguésia 29 (44): 269-306.

. 1978b. Contribuição ao conhecimento da distribuição geográfica das Lauraceas II. Rodriguésia 30 (47): 83-103.

1979a. Contribuição ao conhecimento da distribuição geográfica das Lauraceas
III. Rodriguésia 31 (48): 7-57.

1979b. Contribuição ao conhecimento da distribuição geográfica das Lauraceas IV. Rodriguésia 31 (49): 516.

1979c. Contribuição ao conhecimento da distribuição geográfica das Lauraceas V. Novas localidades de ocorrência nos estados do Paraná e Rio Grande do Sul. Rodriguésia 31 (50): 135-152.

. 1979d. Lauráceas. In: Reitz, R. (ed.). Flora Ilustrada Catarinensis. 50p. 1980a. Contribuição ao conhecimento da distribuição geográfica das Lauraceas VI. Rodriguésia 32: 9-32.

1980b. Contribuição ao conhecimento da distribuição geográfica das Lauraceas VII. Rodriguésia 32 (54): 351-368.

1996. In: Marques, M. do C.M. Espécies Coletadas no Estado do Rio de Janeiro Depositadas no Herbário RB. Rio de Janeiro. 107p.

Vaz, A.M.S. da F., 1992. Diversidade de plantas vasculares na floresta atlântica do Rio de Janeiro. Boletim do Museu Biológico Mello Leitão 1: 77-82.

Werff, H. van der. 1984. Notes on Neotropical Lauraceae. Annals of the Missouri Botanical Garden 71: 1180-1183. 1987. A revision de Mezilaurus (Lauraceae). Annals Missouri Botanical Garden 74: 153-182. 1991. A key to the genera of Lauraceae in the New World. Annals Missouri Botanical Garden 78 (2): 337-387. 1994. Novelties in Neotropical Lauraceae. Novon 4: 58-76. \& Richter, H.G. 1996. Toward an improved classification of Lauraceae. Annals Missouri Botanical Garden 83: $409-418$. 